\title{
Ortega y la Religión
}

Nueva lectura

\section{DIOS A LA VISTA Y DIOS ESCONDIDO}

1. El fin principal de este escrito es tratar de exponer de nuevo la filosofía de la religión en Ortega para así poder cerrar adecuadamente una larga y triste polémica de la vida y la cultura española. Para ello se presentan ordenadamente las diversas teorías de Ortega sobre el sentido de la religión y sus principales problemas en los diferentes campos que nuestro autor ha tratado.

2. En nuestra tarea hemos recogido todos los textos relativos al tema que aparecen en los doce volúmenes de sus Obras completas publicadas por Alianza editorial en 1983. También se han consultado la Biblioteca de Ortega y el Archivo Ortega de la Fundación Ortega y Gasset de Madrid.

3. Las conclusiones más importantes que se desprenden de este estudio son las siguientes:

a) Ortega no habla ex ignorantia, como frecuentemente se suponía, sino ex-abundantia. Es decir, conoce bien el cristianismo de su tiempo y particularmente la investigación teológica más al día presente en Marburgo y Tubinga: Barth, Bultmann, Otto, H. Gunkel, Tillich, etc.

b) Ortega lo que pretende es la modernización adecuada de la religión para ponerla a la altura de los tiempos. Esto supone una doble tarea:

- dotar de una arquitectura teórica más actual al cristianismo, como lo habían hecho en Europa R. Guardini, E. Przywara y M. Scheler, etc., a los que Ortega mismo cita como ejemplos.

- dar al cristianismo una mayor eficacia social en la lucha por la justicia según el espíritu de San Francisco que sirve de referencia continua a Ortega. 
c) Ortega mantiene, fundamentalmente, la misma posición religiosa durante toda su vida, si bien la polémica es unas veces más fuerte que otras. Estas posiciones fundamentales son:

-no al anticlericalismo.

- sí al sentido profundo de la vida 'donde Dios da sus voces'.

- sí a una nueva sensibilidad vital en todos los ámbitos, que habría iniciado ya el 98, y en concreto también a 'un nuevo Dios' (IX 495), que rehará con verdad y justicia la vida española rota.

4. En cuanto al método, veremos que Ortega modifica sustancialmente la ontología griega y la filosofía tradicional poniéndola 'patas arriba'. Por nuestra parte hemos procurado dejar a un lado la polémica. Hemos utilizado el método Jericó como el propio Ortega: exponer serenamente los textos e ir dando vueltas al problema sin precipitarnos a cerrarlo con valoraciones personales apresuradas. Hemos querido que las cosas se demuestren por sí mismas, con sus propias palabras y en sus propios contextos, con detalle y sin apresuramientos.

5. Finalmente diremos que creemos haber sido exhaustivos en lo relativo al tema religioso presente en la obra publicada hasta hoy de Ortega; no literalmente, porque el mismo Ortega se repite con frecuencia, pero sí realmente. 


\section{SIGLAS MÁS UTILIZADAS EN LA BIBLIOGRAFÍA DE ORTEGA}

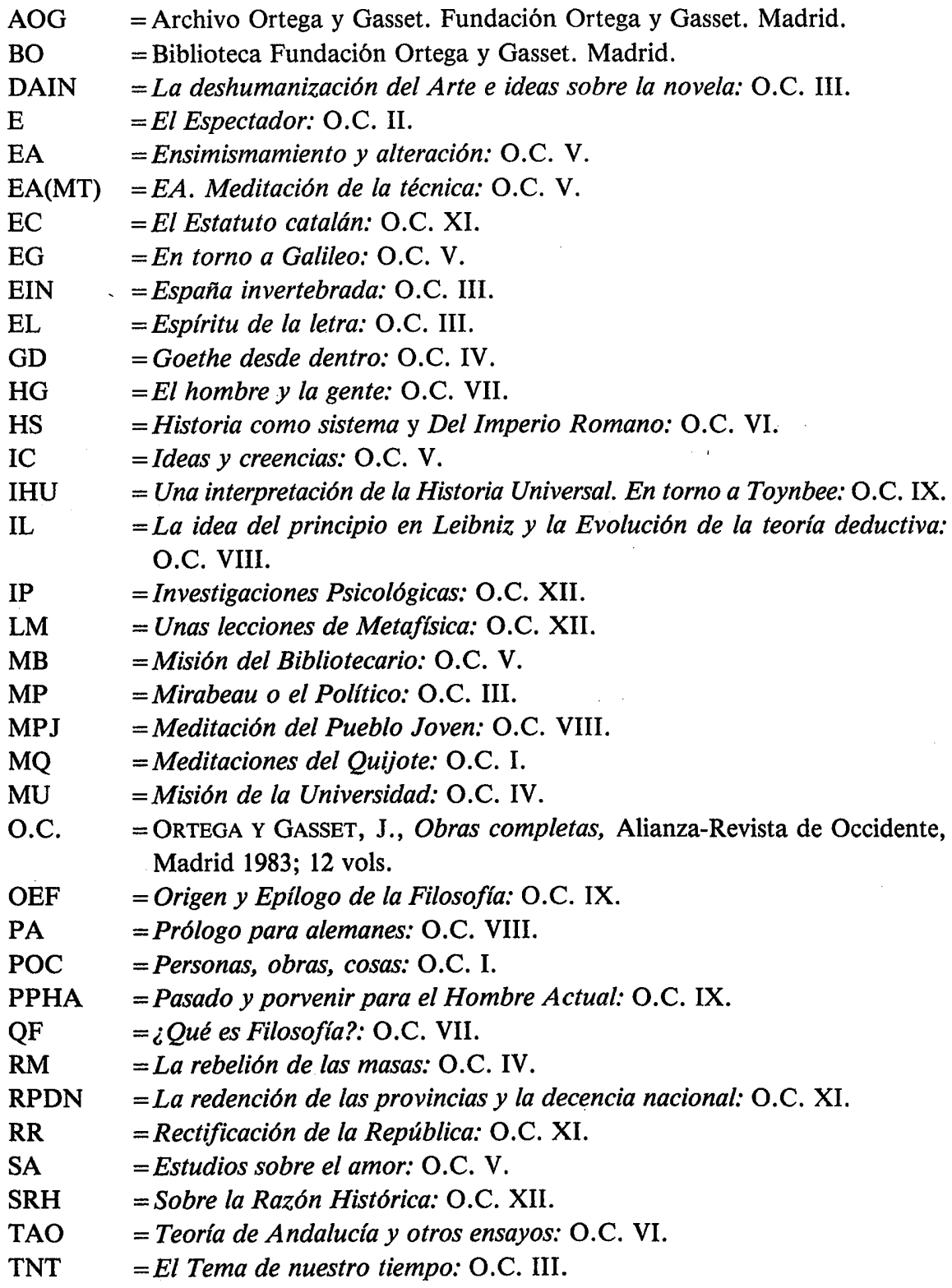




\section{FUENTES Y BIBLIOGRAFÍA}

\section{A. FUENTES INÉDITAS}

MADRID

Archivo Ortega y Gasset

-Epistolario

-Manuscritos

-Notas y bibliografía.

\section{B. BIBLIOGRAFÍA DE PUBLICACIONES SOBRE ORTEGA}

Díaz Díaz, G.-SANTos Escudero, G., Bibliografía filosbfica Hispánica. 1901-1970, C.S.I.C. Instituto de Filosofía 'Luis Vives', Madrid 1982, 849-875.

Donoso, A.-RALEY, H., José Ortega y Gasset: A Bibliography of Secondary Sources, Philosophy Documentation Center, Bowling Green State University, Bowling Green (Ohio) 1986, 444 pp.

Jiménez GARCiA, A., Bibliografía reciente sobre Ortega, en Aporía 6 (1983-84) 165178.

Martínez Gómez, L., Bibliografía filosófica. 'Ortega', en Pensamiento 26 (1970) 483484; 27 (1971) 472-473; 28 (1972) 476-477; 29 (1973) 479-480; 30 (1974) 478; 31 (1975) 464-465; 32 (1976) 481; 33 (1977) 453; 34 (1978) 462-463; 35 (1979) 489.

Santos Escudero, G., Bibliografía filosofica. 'Ortega', en Pensamiento 36 (1980) 475; 37 (1981) 456-457; 38 (1982) 322-323; 39 (1983) 326-327; 40 (1984) 349-353; 41 (1985) 351-354; 42 (1986) 351-352.

RUSKER, U., Bibliografía de Ortega, Revista de Occidente, Madrid 1971. 


\section{INTRODUCCIÓN Y SITUACIÓN}

Hoy día ya no se puede vivir sólo de 'carnes indudables' o exclusivamente de 'certezas metafísicas', si bien sea cierto que mientras alguien crea en una idea «la idea vive» ${ }^{2}$. Esto, sin embargo, no debe decirse ya de las «religiones muertas, de los dioses que traspusieron con sus credos bajo el brazo» ${ }^{2}$. $\mathrm{Ni}$ tampoco de una justicia abstracta, indiferente, que es un 'cuento chino' y una despersonalización que vuelve al hombre al herbario adonde «se irá a posar en una definición de Santo Tomás», como se acomoda el animal expuesto del Zoológico ${ }^{3}$, hasta caer en el «hombre lúgubre de las multitudes que vio Poe» ${ }^{4}$. Ya Montesquieu vapuleó la obediencia a las mayorías ${ }^{5}$ que viven en permanente teatro donde se renuncia, según Nietzsche, «al derecho de hablar y escoger, se renuncia al gusto propio y aun a la misma bravura tal como se posee y se ejerce frente a Dios y los hombres, entre los propios cuatro muros» ${ }^{6}$.

El hombre de Aurora produce un efecto insensato en el 'gran número' a causa de la sinceridad que es la primera cualidad del ser del 'héroe', también según Carlyle ${ }^{7}$. La gente, por su parte, quiere leyes, la justicia seca y aburrida, como razón social de su vida y de su potencia aparente: «'Danos una ley' clamaban circundando a Moisés» ${ }^{8}$. Perdida la propia identidad se busca: «¿Quién nos dirá qué cosa somos nosotros?» ${ }^{9}$. Cada uno tiene su propia respuesta, pero sobre ella, realmente, «aún no han logrado ponerse de acuerdo ni los hombres ceñudos, ni los pueblos creyentes» ${ }^{10}$. Por lo demás «los pueblos son siempre pobres enfermos de la voluntad y no creen en sí mismos» ${ }^{11}$.

Precisamente las pasiones humanas podrán ser dolores purificantes hoy cuando 'todos somos tristes', pobres de espíritu; tenemos, como Valle-Inclán, «ansias de vida libre e instintiva» ${ }^{12}$ y como el Marqués de Bradomín, «aquel

1. Ortega y Gasset, J., Obras completas, I, Alianza, Madrid 1983, 13; 14: «Glosas», Vida Nueva, 1.12.1902. En adelante se cita esta edición de las Obras completas. Se indica el volumen con número romano y las páginas con árabe. Se añade la revista o periódico de la publicación original y la fecha, precedidos del título del escrito.

2. I 14; «Glosas», Vida Nueva, (1.12.1902).

3. Ibid.

4. I 15; «Glosas», Vida Nueva, (1.12.1902).

5. Ibid.

6. I 16; «Glosas», Vida Nueva, (1.12.1902).

7. I 17; «Glosas», Vida Nueva, (1.12.1902).

8. Ibid.

9. Ibid.

10. Ibid.

11. Ibid.

12. I 20 «La 'Sonata de Estío' de Don Ramón del Valle-Inclán», La Lectura (febrero de 1904). 
Don Juan, feo, católico y sentimental» ${ }^{13}$, necesitamos valores reconstituyentes frente a «las severas y arrugadas consejas de la moral contemporánea» ${ }^{14}$. Para Ortega es «muy de admirar hoy tan regocijada disposición de espíritu. No ver sino fuertes y atrevidos brazos, sino amores magníficos en este país de las tristezas, es algo heteróclito y nada frecuente» ${ }^{15}$. Especialmente, cuando pensamos que Valle escribe en unos tiempos «tan anémicos y reglamentarios» ${ }^{16}$. En tal sentido, Valle resulta una roca inatacable, «inútil a las aplicaciones de la industria» ${ }^{17}$. Se trata de un centinela bien alerta más que de un megalómano decadente ${ }^{18}$; como Ignacio de Loyola hace huir a la canalla plebeya cual héroe sagrado. En Valle no hay ser mediocre, en él hasta los «clérigos y frailes campanudos y mujeriegos» ${ }^{19}$ son hombres de alta aventura.

Todo es en Valle atroz: son sus personajes «o atrozmente sencillos, o atrozmente voluntarios» ${ }^{20}$. Valle conoce lo pintoresco frente a los escritores fríos y oficiales patrocinados por $« \mathrm{D}$. Juan Valera, ese Dios-Pan sonriente y ciego que perdura en el yermo jardín de nuestras letras como la estatua blanca y rota de una deidad gentílica» ${ }^{21}$. Para el arte es «preciso el Dolor que nos hace tan humanos» ${ }^{22}$.

Valle es un adorador de nuestra lengua pero enemigo de «toda trascendencia, nudo artista y trabajado creador» ${ }^{23}$. Valle encanta a Ortega, pero éste desearía se dejara aquél de bernardinas y nos contara cosas «humanas, harto humanas en su estilo noble de escritor bien nacido»" ${ }^{24}$.

Pues ciertamente la vida tiene dimensiones misteriosas y es el caso, por ejemplo, que para ver el teatro de Maeterlinck, es necesario colocarse más allá de la vida momentánea: «acaso cierto refinado gustador de las bellezas leería antes algunos capítulos de Santa Teresa, Novalis, Taulero o Ruysbrocho, algunas de esas páginas que hacen vibrar el cerebro y nos recluyen dentro de no-

\footnotetext{
13. Ibid.

14. I 21; «La 'Sonata de Estío' de Don Ramón del Valle-Inclán», La Lectura (febrero de

15. Ibid.

16. Ibid.

17. Ibid.

18. I 22; «La 'Sonata de Estío' de Don Ramón del Valle-Inclán», La Lectura (febrero de

19. I 25; «La 'Sonata de Estío' de Don Ramón del Valle-Inclán», La Lectura (febrero de

20. Ibid.

21. I 26; «La 'Sonata de Estío' de Don Ramón del Valle-Inclán», La Lectura (febrero de

22. Ibid.

23. Ibid.

24. I 27; «La 'Sonata de Estío' de Don Ramón del Valle-Inclán», La Lectura (febrero de
} 1904). 1904). 1904). 1904). 1904). 
sotros mismos»" ${ }^{25}$. Son atisbos de un 'mundo desconocido', corazonadas de algo grande y extraño, sin límites, provincias de misterio del que sólo vemos el revés. Mil cosas inexplicables que podemos acallar en la vida cotidiana «pero en cuanto nos quedamos solos se erguirá a nuestro lado el 'misterio', como un compañero sombrío, mudo, que ignoramos de dónde viene y hace camino con nosotros. Aunque cultivemos el escepticismo más perfecto, aunque empapemos los sentidos en todos los placeres, aunque cerremos a fuerza de razonamiento las ventanas de nuestro interior, el 'misterio' nos acosará, nos atormentará, murmurará en derredor como un enjambre de abejas invisibles, y en el paroxismo del sufrimiento o del goce notaremos una llamada, una sugestión que nos da una noticia, que nos recuerda, que nos previene que va a pasar algo» ${ }^{26}$.

Se trata de un mundo inefable, pues como cuando tenemos que decirnos algo importante nos callamos, como ante el misterio del dolor, la muerte, la fatalidad o el porvenir, todo auténtico misterio deja «mudos los seres» ${ }^{27}$. Tal es el misticismo español de Maeterlinck: «El escritor belga es nieto de los ardientes españoles que compusieron 'Las Moradas', 'La cuna y la sepultura' y 'Tratados de amor divino' ${ }^{28}$. El pathos del misticismo es «el poso íntimo del alma española» ${ }^{29}$. Si aquél fue fuerte, los españoles luchamos, si era torpe nos paramos y si somnoliento nos adormecimos. Pero verdaderamente «los místicos han estado durante todos los tiempos de pie en la frontera de lo desconocido: han sido los vigías de la humanidad que, izados en el ensueño o en el éxtasis dan las voces de alerta al divisar las brumas rosadas que anuncian costa. Los sabios, con toda su impedimenta y sus andares de camellos cansados, llegan a las tierras prometidas siglos más tarde que los videntes. $Y$ esto es una amarga burla del hado, porque sabio podrá serlo quien quiera, y vidente sólo el que lo sea desde la eternidad» ${ }^{30}$.

Parece que nuestras misteriosas tierras hayan sido contempladas antes por un vidente hindú o por una virgen asceta. Ellos saben que los poderes superiores juegan con nosotros pues «nuestra ilusión de libre albedrío -según Spinoza- no es más que nuestra ignorancia de las causas que nos hacen obrar» ${ }^{31}$. Tal es el ambiente de las creaciones teatrales de Maeterlinck, cual claraboyas hacia lo desconocido que una vez avisados, sin duda, conviene ol-

25. I 28; «El poeta del misterio», El Imparcial (14.3.1904).

26. I 29; «El poeta del misterio», El Imparcial (14.3.1904).

27. I 30; «El poeta del misterio», El Imparcial (14.3.1904).

28. I 31; «El poeta del misterio», El Imparcial (14.3.1904).

29. Ibid.

30. Ibid.

31. I 32; «El poeta del misterio», El Imparcial (14.3.1904). 
vidar para guardarnos «de lo que un pobre loco de Sils María llamaba 'alucinaciones del Tras-mundo'» ${ }^{32}$.

Sabemos, además, que la vida necesita siempre de cierta aventura, como de la arriesgada sinceridad del campo frente al espíritu superprudente del urbanita. Es el embrujo de la vida más allá de la pura instintividad o/y la fría socialidad. Así las mujeres han conservado las civilizaciones, porque en ellas las angustias del cuerpo se abrevan en el torrente de su alma «nunca harta de existir y soñar» ${ }^{33}$. Aquí la vida reina invencible, es la «mujer mística a un tiempo y brava que irradia el regocijo» ${ }^{34}$. Corona la existencia humana un aire de imprudencia, lance y atrevimiento donde las estrellas no quedan disecadas en «condecoraciones» ${ }^{35}$.

Esa perspectiva no debe reducirnos a una visión puramente volcánica de la vida. La razón y la ciencia tienen puesto conductor en la aventura humana. $\mathrm{Y}$ aunque en España ha abundado la desatención intelectual, constituye un deber sagrado la disciplina, el esfuerzo y el trabajo intelectual en nuestra tierra. En esta línea, todo libro, tiene sentido de valor nacional. El escritor debe ser despertador de desatentos o la fecundidad de la ciencia y el arte quedará «seca y estéril como la higuera del Evangelio» ${ }^{36}$.

Es cierto que hasta ahora, ha predominado la dispersión: «De esta suerte está salpicada y esparcida el alma española en sinnúmero de círculos discretos y es la vida española un montón de avemarías desglosadas que jamás se enhilan en rosario» ${ }^{37}$. Para Ortega no ha habido ciencia española, como sostiene Menéndez Pelayo, pero sí que ha habido hombres de ciencia. Y a los que no quieren ciencia española hay que darles el 'Dios le ampare', pues no quieren cultivar nuestra propia alma; porque ciencia española ha de haber: «Necesitamos ciencia a torrentes, a diluvios para que se nos enmollezcan, comó tierras regadas, las resecas testas, duras y hasta berroqueñas. Pero los que más predican la buena nueva de la ciencia no han advertido que quieren que tengamos ciencia alemana o ciencia francesa pero no ciencia española» ${ }^{38}$.

Tal ciencia no puede quedar en pura mineralogía, sabiduría abstracta o teología aérea. Hay una tiesura y una soberbia rígida, la de los españoles, que nos impiden el intercambio y la comunicación cultural verdadera. Cada uno se convierte en una isla de vanidad, desierta, donde todo el mundo quiere ser to-

\footnotetext{
32. Ibid.

33. I 36; «El rostro maravillado», El Imparcial (25.7.1904).

34. Ibid.

35. I 37; «El rostro maravillado», El Imparcial (25.7.1904).

36. I 38; "La ciencia romántica», El Imparcial (4.6.1906).

37. Ibid.

38. I 41; «La ciencia romántica», El Imparcial (4.6.1906).
} 
do o nada, el primer de todos y 'original' en exclusiva ${ }^{39}$. Y por lo mismo que debe huirse la pereza individual y colectiva nos hace falta recuperar épocas de «intimidad afable y respetuosa, de intimidad familiar, preparadora de los renacimientos» ${ }^{40}$. Pues lo más triste es cuando falta la comunicación de la vida, de la cultura, del secreto de esa vida y la conciencia mejor; pues «hay que ser fuente, manantial, profunda veta de humanidad que resume (sic) santa energía estética, renovadora, impulsora, consoladora» ${ }^{41}$.

Ortega se adscribe férreamente, sobre todo y desde el principio, al mundo de los vivos: «Nosotros, menos sutiles, somos vivívoros, nos alimentamos de terrenas bestezuelas y plantas y a un lugar teológico preferimos cualquier cosa orgánica, aunque sea una de esas agallas oscuras y feas que sobre el árbol formó la mística fecundidad de un cínife, una de esas agallas que buscaba yo, cuando muchacho, afanosamente, por las robledas de El Escorial, para componer una tinta maravillosa que no he llegado a hacer nunca» ${ }^{42}$.

El pensador y el artista no pueden ser ajenos a los dolores y sufrimientos de los mortales, a la vida sórdida marginal; por eso el arte es un camino de liberación, como dice Schopenhauer, de los problemas de la vida y de la vulgaridad. En otro caso se es un filisteo y no un hombre de letras presente en la realidad del Dolor humano: «Si no estás sumido en las grandes corrientes del subsuelo que enlazan y animan todos los seres, si no te preocupan las magnas angustias de la humanidad, a despecho de tus lindos versos a unas manos que son blancas, a unos jardines que se mueren por el amor de una rosa, a una tristeza menuda que te corretea como un ratón por el pecho, no eres poeta, eres un filisteo del claror de la luna» ${ }^{43}$. Y esto es así, en definitiva: «Porque sobre la totalidad de una vida, con su nacimiento y su muerte, gravita a la vez, forzosamente, en más remota esfera, el doliente corazón silencioso del UnoTodo» ${ }^{44}$.

Bajo ese filisteísmo, la campiña de España ha estado empapada de dolor e inundada de pesimismo, transida de 'dogmatismo y retórica', mientras sus poetas y escritores han permanecido «como las 'madreperlas' — según habla san Francisco de Sales- que viven en medio del mar sin que entre en ellas una sola gota de agua marina” ${ }^{45}$. Mientras la muerte y la miseria reinan, los hombres y las mujeres se embelesan con el canto de sus canarios.

39. I 47; «Crítica Bárbara», El Imparcial (6.8.1906).

40. Ibid.

41. I 50; «Poesía nueva, poesía vieja», El Imparcial (13.8.1906).

42. I 45; «Crítica Bárbara», El Imparcial (6.8.1906).

43. I 51; «Poesía nueva, poesía vieja», El Imparcial (13.8.1906).

44. I 52; «Poesía nueva, poesía vieja», El Imparcial (13.8.1906).

45. Ibid. 
Entre tanto dolor, en el campo español de la raya de Segovia frente al Guadarrama, aparece Rubín de Cendoya «místico español, un hombre obscuro, un hombre ferviente» ${ }^{46}$. En esta montaña se reúnen con Ortega las generaciones de españoles muertos, los celtíberos «con voluntad suprema de perdurar sobre toda mudanza» ${ }^{47}$. Y a pesar de que el hombre parece ser una 'casualidad' subrayada por el anonimato de la ciudad, «el tiempo, en su huidez, hace vacilar nuestros ánimos, que el tiempo es un temblor incesante y eterno. Un ansia infinita de permanencia transciende de lo más adentrado de nosotros, en tanto que la razón nos anticipa la imagen de una muerte cierta. Frente a ese problema trágico, insoluble, se evapora el individuo» ${ }^{48}$.

Ortega promete aquí una 'Pedagogía del paisaje' frente a la admirable 'Pedagogía social' de Natorp, pues el paisaje le ha iniciado a Ortega 'en una religión', como la casa de campo enseñó a Séneca el arte de envejecer ${ }^{49}$.

Al paisaje y a la arboleda perdida, vuelven siempre los hombres sabios como los antiguos creyeron que las almas de los muertos iban a habitar las ramas de los árboles y, por eso, quizá, «Renan dice que el instinto religioso es en el hombre lo que el instinto de nidificación en el pájaro: nada extraño tiene que, como las aves labran sus nidos en los árboles, hagan de ellos sus altares los hombres» ${ }^{50}$.

El campo sabe de soledad y de paz, pero también hay campos malditos, siniestros y hostiles que huelen a traición comprada por «treinta dineros» ${ }^{51}$. Por lo general, la Naturaleza enseña al hombre la serenidad, la sencillez, la libertad sin trampas: No tiene opinión (Nietzsche) ni prejuicios sobre nosotros y por eso nos gusta tanto. Sin embargo, esa Naturaleza «murió hace muchas centurias envenenada por un silogismo» ${ }^{52}$. En ese tiempo, los españoles, como Ortega y su acompañante, no tenemos hora ni relojes «porque éramos místicos y celtíberos» ${ }^{53}$; como los adamitas avanzan, pues, a rastras cargados con «la gravedad perenne del desencanto» ${ }^{54}$ y bajo el signo de la muerte: « ¡Bebiotai, bebiotai! ¡Ha vivido, ha vivido! decían entonces los griegos» ${ }^{55}$. Los grandes pueblos se formaron 'en la religión de los difuntos' y sus virtudes inmortales quedaron como arcos rotos «eternamente proyectados sobre el vacion".

46. I 53; «La pedagogía del paisaje», El Imparcial (17.9.1906).

47. Ibid.

48. I 53-54; «La pedagogía del paisaje», El Imparcial (17.9.1906).

49. I 54; «La pedagogía del paisaje», El Imparcial (17.9.1906).

50. I 55; «La pedagogía del paisaje», El Imparcial (17.9.1906).

51. Ibid.

52. I 56; «La pedagogía del paisaje» El Imparcial (17.9.1906).

53. I 57; «La pedagogía del paisaje» El Imparcial (17.9.1906).

54. I 58; «Canto a los muertos, a los deberes y a los ideales», El Imparcial (14.9.1906).

55. Ibid.

56. I 59; «Canto a los muertos, a los deberes y a los ideales», El Imparcial (14.9.1906). 
¡He aquí el hombre! Todo hombre es proyecto y pasión. Pero permanece siempre el Deber, «el deber del trabajo» ${ }^{57}$, según el tiempo, la esperanza, la libertad y las dos grandes virtudes de los modernos: «el cumplimiento de los deberes oscuros y el idealismo inmarcesible» ${ }^{58}$. Ése es el hombre: el dolor de lo oscuro, sin flores y con frutos invisibles; no el de los grandes conquistadores de reinos o fundadores de religiones: «No, no, ésos son llamamientos unipersonales con que Dios regala a algunos hombres y que en el fondo les ensoberbecen. Hablo del deber anónimo... ${ }^{59}$. El de los tiempos nublados. Pues Dios impone a la Historia épocas claras y tiempos oscuros y nuestro deber es acudir lealmente a la cita, sin hurtarla y trabajar en todo tiempo y lugar. Tal es «el antiguo y conocido campo del Deber, es el lugar de liza y de hazañas para los modernos caballeros, y cumplir en el paso honroso de la Obligación, la muestra más cierta de virilidad» ${ }^{60}$.

Hay que resucitar a quienes señalaron este camino con su trabajo sobre la realidad para 'fundar la idealidad'. Lo que llamamos experiencia, en cambio, no es con frecuencia sino la quiebra en «el olvido de esas difíciles verdades eternas que nos impulsan a la guerra santa contra la realidad» ${ }^{61}$, a la aventura del ideal, a ser 'argonauta del ideal' como se definía a sí mismo Nietzsche y como fue aventura para Ortega su amigo Navarro Ledesma.

Según la mitología, el campo y Dios-Pan se amaron, y Dios-Pan amó a Siringa. $\mathrm{Y}$ «este amor doloroso fue la flor de su vida eterna y desde entonces amó todas las cosas estrictamente como sólo Pan ama» ${ }^{62}$. Y en Europa «como en Siringa se hizo la bestia Pan, Dios Pan, se hizo hombre en Grecia la blanca bestia. Sin la disciplina helénica sólo hubiera sido una posibilidad hacia lo humano, como lo fueron la bestia metafísica asiática o la bestia totemista de África» 63 .

Sin esa humanización ética no hay auténtico progreso, que es lo decisivo, mostrado en las tareas 'sobrenaturales' como la 'institución del socialismo' o el fomento del 'sobrenombre'» (sic) ${ }^{64}$. Sin esa cultura no hay cultivo de lo 'específicamente humano', cuyo embrión está en el clasicismo griego y su fenecimiento «en lo infinito, donde el hombre impondrá la urna de su corazón cocida en el horno de Grecia por un alfarero socrático» ${ }^{65}$. La tarea es delicada y

57. I 60; «Canto a los muertos, a los deberes y a los ideales», El Imparcial (14.9.1906).

58. Ibid.

59. Ibid.

60. I 60-61; «Canto a los muertos, a los deberes y a los ideales», El Imparcial (14.9.1906).

61. I 61; «Canto a los muertos, a los deberes y a los ideales», El Imparcial (14.9.1906).

62. I 64; «Sobre los estudios clásicos», El Imparcial (28.10.1907).

63. Ibid.

64. I 64-65; «Sobre los estudios clásicos», El Imparcial (28.10.1907).

65. I 65; «Sobre los estudios clásicos», El Imparcial (28.10.1907). 
un pequeño fallo en los principios de la cultura termina siempre al fin en un desfalco histórico.

Entre el clasicismo heredado y el clasicismo propio hay un credo fluyente, en constante superación, y un cauce sin mudanza. Ni sirve la chabacanería ni tampoco un clasicismo que abrasa el porvenir en «un altar consagrado al Dios de los muertos» ${ }^{66}$. No es admisible un romanticismo del mal ni un dualismo entre clásicos y románticos, como entre Ormuz y Arimán. El mal no es haber nacido como cree impíamente el sacerdote Calderón. «Éste es el único pesimismo admisible y piadoso, religiosamente humano: no el pesimismo de ser desventurados, sino el pesimismo de no poder ser mejores» ${ }^{67}$.

El romanticismo es la sombra del mal y el mal el fantasma del bien: «La experiencia de la virtud sólo es posible por el vicio. Éste es, a mi entender, el hondo sentido que orienta el dogma cristiano del pecado original, cuyo sentido transcribe menos pintorescamente Kant cuando nos habla del «mal radical» en el hombre. Porque siendo para él el hombre aquel ser capaz de mejorarse indefinidamente, ocurrirá que en cada instante es malo por bueno que sea, si se le compara con lo puede llegar a ser en el instante siguiente. El hombre es radicalmente, originalmente malo» ${ }^{68}$. Esto se ve abiertamente en las virtudes y las constituciones políticas cuando éstas dicen del absolutista 'por la gracia de Dios' y por eso queremos siempre cambiarlas por otras de mayor igualdad social y económica para mejorar siempre.

Lo que llama Kant mejorar le llama Nietzsche sobrehombre y éste es «la mejora del hombre, y el hombre debe ser superado porque aún puede ser mejor» ${ }^{69}$. Ésta es la única interpretación posible, para Ortega, del superhombre de Nietzsche.

El hombre, por otra parte, es una tragedia, como lo expresa el cuadro de Tiziano «Amor divino y amor humano», pues no sabemos muy bien cuál es la realidad divina y cuál la humana que engendran la resonancia generosa y abundante en los hombres ${ }^{70}$. Cierto que el amor desinteresado es muy español pero también somos una gente muy presuntuosa. Y en cada nación aparece el vicio y la perversidad de una manera distinta «y a ésta llamamos carácter nacional» ${ }^{71}$ como advirtió Schopenhauer.

La insolidaridad o el centralismo revelan una profunda crisis en el alma

66. I 73; «Teoría del clasicismo», II, El Imparcial (2.12.1907).

67. Ibid.

68. I 74; «Teoría del clasicismo», II, El Imparcial (2.12.1907).

69. Ibid.

70. I 75; «Teoría del clasicismo», II, El Imparcial (2.12.1907).

71. I 80; «Viaje a España en 1718», El Imparcial (13.1.1908). 
española según aquel irónico manuscrito de Londres sobre España cuyo índice «comienza así:

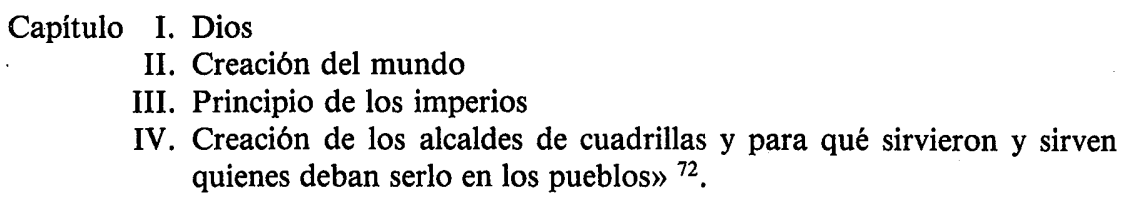

España anda como un fantasma. No ha tenido modernidad, ni siquiera en matemáticas o en filosofía. La vida española padece un profundo mal. En efecto, «la sustancia española está enferma hace siglos, y es su mal tan profundo, que no hallaremos en la historia de España político con genio suficiente para atribuirle los inferidos daños» ${ }^{73}$. No es posible hacer arreglos fáciles. No basta lo espontáneo, lo liberal o anarquista; precisamente hay que crear una nueva intimidad, «una nueva espontaneidad, un yo contemporáneo, una conciencia actual. En otras palabras, tenemos que educarnos» ${ }^{74}$.

No vale recurrir aquí a fuerzas biológicas, pues somos una raza muerta. Al contrario: «Preferible fuera usar comparaciones teológicas; porque en verdad se trata de una resurrección» ${ }^{75}$. El verdadero patriotismo debe ser reflexivo y cuidadoso con las ciencias y la cultura. Puesto que «el problema español es un problema educativo; pero éste, a su vez, es un problema de ciencias superiores, de alta cultura» ${ }^{76}$.

Hay que hacer bibliotecas y crear una moralidad científica, leer los documentos históricos y estudiar Platón, Descartes y Kant. No basta creer en el "'Deux (sic) ex machina' económico» ${ }^{77}$. Hay que tener sentido de la paradoja y saber distinguir unas cosas de otras y no mezclarlo todo como hace, con frecuencia, la cultura del sentido común, sin advertir las confusiones; como observa Ortega de una obra famosa: «Hace poco tiempo, leyendo el libro de Don Leclerq sobre la España cristiana, me tomó una gran risa al sorprender un párrafo de Renan intercalado, sin advertencia, entre los otros mansos del buen fraile» ${ }^{78}$.

Ortega, no oculta, que ha pasado, a los 18 años, por la 'zona tórrida' de Nietzsche, pero ya ha arribado a «regiones de más suave y fecundo clima» ${ }^{79}$. Nietzsche llevó a muchos, como a Ortega a enfrentarse con orgullo a la chaba-

\footnotetext{
72. I 82; «Pidiendo una Biblioteca», El Imparcial (21.2.1908).

73. I 82-83 «Pidiendo una Biblioteca», El Imparcial (21.2.1908).

74. I 84; «Pidiendo una Biblioteca», El Imparcial (21.2.1908).

75. Ibid.

76. Ibid.

77. I 86; «A. Aulard: Taine, historien de la révolution française», El Imparcial (11.5.1908).

78. I 89; «A. Aulard: Taine, historien de la révolution française», El Imparcial (11.5.1908).

79. I 91; «El sobrehombre», El Imparcial (13.7.1908).
} 
canería cultural española y a la moral de rebaño. En tal sentido «fue nuestro orgullo una de esas mentirijillas benéficas y necesarias merced a las cuales va el mundo poco a poco hacia una organización superior y forman parte de lo que Renan -isiempre Renan! - llamaba plan jesuítico de la naturaleza» ${ }^{80}$.

Con Nietzsche, Schopenhauer y el 98 lucha Ortega por la definición del hombre que es el gran problema de la filosofía y de la vida: «La definición del hombre, verdadero y único problema de la Ética, es el motor de las variaciones históricas. Por eso los gobernantes han perseguido en todo tiempo la «moralita», explosivo espiritual, y han hecho lo imposible para precaverse ante el terrorismo de la Ética» ${ }^{81}$. Nietzsche busca una nueva moral y antes un hombre nuevo, pero se pone más allá del bien y del mal «estatuido por la moral greco-cristiana, con quien es necia y groseramente injusto» ${ }^{82}$.

Con todo no se crea que Nietzsche propone el individualismo o el libertinaje snob, vapuleado por Zarathustra, o el mero gozar, como ideal ético. Al contrario su moral es «rigidez y dureza consigo mismo» ${ }^{83}$, así como la afirmación libre de la vida. Se trata de romper con la falsedad y la mascarada hasta encontrar el manantial de Kant y Leibniz. Hay que descubrir, con la veracidad estética de nuestros pintores españoles «la visión de la vida real, terriblemente precisa y sin equívocos, 'de este valle de lágrimas - según decía Sancho- de este mal mundo que tenemos, adonde apenas se halla cosa que 'esté sin mezcla de maldad, embuste y bellaquería'» ${ }^{84}$.

Por otro lado el manantial de Europa debe fecundar la vida española, con elegancia y sin petulancia, según recomendara Joaquín Costa — «el celtíbero cuya alma alcanza más vibraciones por segundo»- ${ }^{85}$. Europa es muchas cosas, como lo es el hombre que es tanto el animal que bebe sin sed y hace el amor en todo tiempo como el "petit Dieu» de Leibniz ${ }^{86}$.

Es necesario aclararse y no tener miedo a la luz como los «místicos y los mixtificadores» ${ }^{87}$; emprender la aventura de inventar «porque del cielo no caen las máquinas de vapor ni la economía política, ni los 'policemen', que si cayeran, en casa tenemos la Pilarica que nos hubiera donado tan bellas y útiles sustancias, y sin trabajo alguno por nuestra parte las hubiéramos piadosamente recibido en medio de esta regocijada danza de la Muerte, que España va

80. I 92; «El sobrehombre», El Imparcial (13.7.1908).

81. I 93; «El sobrehombre», El Imparcial (13.7.1908).

82. Ibid.

83. I 95; «El sobrehombre», El Imparcial (13.7.1908).

84. I 98; «Meier-Graefe», El Imparcial (9.7.1908).

85. I 99; «Asamblea para el progreso de las ciencias», I, El Imparcial (27.7.1908).

86. I 100; «Asamblea para el progreso de las ciencias», I, El Imparcial (27.7.1908).

87. Ibid. 
danzando siglos hace, donde todos servimos de gigantes y algunos de cabezudos» ${ }^{88}$.

Bien es cierto que la vida no son las máquinas ni la exactitud porque «la verdad no es nunca lo que vemos, sino precisamente lo que no vemos» ${ }^{89}$. Y así ocurre tanto en la ciencia de la luz como en la biografía de cada hombre 'eternamente dudoso', como en Sócrates, a la vez, «mordaz y profundo, severo y reidor, panza al trote y ascético» ${ }^{90}$. La educación consiste precisamente en restaurar ese hombre inefable; eso es europeizar y hacer la Nueva España ${ }^{91}$, la que debe pasar por el eje de la cultura en vez de creerse el 'ombligo de la tierra'. «Si creemos que Europa es 'ciencia', habremos de simbolizar a España en la 'inconsciencia', terrible enfermedad secreta que cuando infecciona a un pueblo suele convertirlo en los barrios bajos del mundo" ${ }^{92}$.

Está esa España 'viuda del alma', sin cerebro y sin ministerio de dirección espiritual, sin saber a donde va; no debe maldecir del pueblo, divino inconsciente, sino de los dirigentes y catedráticos «de nosotros todos los que llevamos en el pecho cien atmósferas de vanidad personal»... «En una palabra, nosotros, que pretendemos ser no-pueblo, tenemos que abrazarnos a nuestros pecados históricos y llorar sobre ellos hasta disolverlos y meter ascuas de dolor en nuestra conciencia para purificarla y renovarla» ${ }^{93}$. Para Ortega: «Es preciso que nosotros, los responsables seamos la virtud de nuestro pueblo y que éste pueda decirnos, como Shelley de una persona que amaba: «'Tú eres mi mejor yo'» ${ }^{94}$.

Según Ortega, además de periódicos y tertulias, debe haber ciencia que es «la única garantía de supervivencia moral y material en Europa» ${ }^{95}$. Ortega no desglosa bienestar material y moral: «Más acertado me parece pensar, con el católico Bonald, que el Gobierno debe hacer poco por los placeres (del pueblo), bastante por sus necesidades, todo por sus virtudes, si se añade que la buena alimentación y la vida grata son el único clima donde se recogen henchidas cosechas de moral. Cabe ser idealista a la manera de Platón, y no olvidar, como él no olvidó nunca, la terrible ironía de Focílides: Cuando se tiene de qué vivir puede pensarse en ejercitar la virtud» ${ }^{96}$.

88. Ibid.

89. I 101; «Asamblea para el progreso de las ciencias», I, El Imparcial (27.7.1908).

90. Ibid.

91. I 103; «Asamblea para el progreso de las ciencias», I, El Imparcial (27.7.1908).

92. I 104; «Asamblea para el progreso de las ciencias», I, El Imparcial (27.7.1908).

93. I 105; «Asamblea para el progreso de las ciencias», II, El Imparcial (10.8.1908)

94. I 106; «Asamblea para el progreso de las ciencias», II, El Imparcial (10.8.1908).

95. Ibid.

96. I 107; «Asamblea para el progreso de las ciencias», II, El Imparcial (10.8.1908). 
La miseria espiritual de España no es menos horrible. Cuando Azorín critica a Ortega y le acusa de escribir para demostrar la amplitud de sus lecturas, éste le replica sobre la miseria cultural de España en cuyas bibliotecas públicas no están las obras de Fichte, Kant o Harnack y que «arrastramos una deuda secular de espíritu» ${ }^{97}$. El caso de Cajal no varía básicamente la situción por ser excepcional. La ciencia española necesita jóvenes desprendidos y generosos para salvar la dignidad intelectual y moral española: le han faltado a España grandes idealistas. Cervantes lo fue a medias: «amó demasiado, se quedó en San Francisco» ${ }^{98}$. No tuvo el valor de apalear los vicios. «En cambio, véase qué hijas nos nacieron: la moral senequista, la moral jesuítica, dos beatas lascivas. Y por hijos tuvimos al quietismo y el conceptismo, iqué asco! Tras un siglo de haber sido formulado el 'imperativo categórico' no ha habido dos docenas de españoles que le hayan mirado frente a frente, de hito en hito, y aun está por estrenar en España esa navaja de afeitar vicios» ${ }^{99}$.

Ortega disputa con Maeztu sobre la necesidad de hombres de ideas para hacer España. Lo hace sin dogmatismo, con rigor técnico, como al que le importa la verdad y el ser, aunque todos caemos a veces en el pecado de la 'autobiografía'. Y esto tampoco debe impedir que la estética tenga un lugar importante junto a la ciencia y la moral. Rubén Darío y Valle o Cájal tendrán siempre un puesto en el cielo y no en el infierno de la frivolidad. Lo mismo ocurrirá con los grandes inventores y con los que comentan a 'Esquilo o san Agustín'. Una cosa es segura: «O se hace literatura o se hace precisión o se calla uno" ${ }^{100}$. Pero siempre cabe hacer algo interesante. Y si no se hace, no basta con recurrir a la explicación de la abulia española como hace Ganivet, ya que «sin ideas precisas, no hay voliciones recias» ${ }^{101}$. Y en España «vamos haciendo del equívoco una industria nacional» ${ }^{102}$. Es necesario, por tanto, ordenar y sistematizar: «El sistema es la honradez del pensador» ${ }^{103}$. Cierto que Hegel es un sistema exagerado de evolución infinita, también lo son Kant y Fichte a su manera; pero eso no dispensa de unificar el alma española tan dispersa y disgregada.

Ortega defiende las mismas ideas políticas que Unamuno y aunque éste sea demasiado turbulento, él es «nuestra vanguardia en esta nueva guerra de independencia contra la estolidez y el egoísmo ambientales» ${ }^{104}$. Lo difícil es conver-

97. I 108; «Asamblea para el progreso de las ciencias», II, El Imparcial (10.8.1908).

98. I 109; "Asamblea para el progreso de las ciencias», II, El Imparcial (10.8.1908).

99. I 109-110; «Asamblea para el progreso de las ciencias», II, El Imparcial (10.8.1908).

100. I 113; «Algunas notas», Faro (9.8.1908).

101. Ibid.

102. Ibid.

103. I 114; «Algunas notas», Faro (9.8.1908).

104. I 118; «Sobre una apología de la inexactitud», Faro (20.9.1908). 
tir a todo un pueblo al trabajo, a la justicia y a la honradez. Eso no se consigue con unos simples ejercicios espirituales laicos. Pero tampoco puede hacerse con las vulgaridades de Nietzsche o con la mecánica del pragmatismo que según Ortega "es una vergüenza para la seriedad científica del siglo XX»" ${ }^{105}$.

La ignorancia es el problema clave de España: «'Si Don Juan hubiera tenido ingenio habría descubierto la virtud'» - dice Stendhal-. Si en España hubiera habido economistas, se habría robado menos; si hubiera habido filósofos, el materialismo religioso no habría raído de nuestras entrañas étnicas todas las aspiraciones nobles; si hubiera habido ciencia ética sobre la económica, la idea severa de democracia no habría fenecido. En una palabra: la ciencia hubiera plantado sus riquezas del futuro, de porvenir, de ideal en la línea de nuestros horizontes y hoy tendríamos algo que anhelar, que querer» ${ }^{106}$.

No basta la buena voluntad, hay que tener idea e ideal. Con insultar tampoco mejora la cosa. Así «el origen del pragmatismo habría que buscarlo en el enojo que algunos sienten contra la ciencia, porque no ha demostrado aún la realidad de Dios y la inmortalidad del alma. Por eso cuando llaman a la ciencia instrumento sienten fruición como si al hermano enemigo llamaran raca» ${ }^{107}$.

En cualquier caso, no podemos cruzarnos de brazos a esperar «que Dios, aprovechando el paso de una constelación favorable, haga llover sobre España hombres honrados. Tal doctrina fatalista me encoge el corazón»" ${ }^{108}$.

Maeztu propone 'la propaganda y difusión de la vida de fe', como solución a los problemas de España; para Ortega: «Las religiones, como sustancias transferibles y expansivas, han fenecido para siempre. Los movimientos políticos del siglo XIX, en cambio, han nacido de representaciones científicas. Una propaganda de actos de fe es una anacronismo. Otra cosa sería una propaganda con fe de ideas científicas, o por lo menos, precisas. Pero de esto último no se me ha ocurrido nunca dudar» ${ }^{109}$.

A Ortega le parece una repetición de frivolidades decir que los ingleses carecen de ideas generales o que entre los semitas es imposible la metafísica (Renan) o que los indoarios son metafísicos por el arroz. Pero esto mismo es lo que hace Maeztu cuando llama a los universitarios 'brahmines'. Para Ortega el estudio científico es fundamental. La verdad no tiene otro camino, 'La fe sólo lleva a creer', pero las buenas intenciones necesitan métodos apropiados y rigurosos. En otro caso se cae en el reproche de Heine a cierta orquesta la-

105. I 119; «Sobre una apología de la inexactitud», Faro (20.9.1908).

106. Ibid.

107. Ibid.

108. I 120; «Sobre una apología de la inexactitud», Faro (20.9.1908).

109. I 121; «Sobre una apología de la inexactitud», Faro (20.9.1908). 
mentable: «iEstas buenas gentes y malos músicos!» ${ }^{110}$. Además Maeztu, según Ortega, dice cosas insostenibles sobre Platón y sobre Kant. Con todo, Ortega está agradecido al trato de Maeztu que, por añadidura, «irradia benevolencia y ternura hacia todos los dolores de esta raza sin fortuna ni esperanzas» ${ }^{111}$.

En España, con frecuencia, nos dedicamos a destruirnos unos a otros, mientras los demás pueblos organizan la paz. Ahora bien las energías de las paz hay que crearlas. Su órgano creador es la Universidad «tanto hay de paz en un Estado cuanto hay de Universidad» ${ }^{112}$. La paz es el ideal de la 'justicia absoluta', del mundo nuevo y la tierra nueva donde está la libertad. Y esto a pesar de todo; a pesar de ser arrojados a este mundo (Renan). Esta paz no se da, se conquista: «En los libros de estoicos y ascéticos se habla de una paz interior que sabios y santos conservan en medio de las mayores turbulencias y contratiempos. Esta paz íntima, esta tranquilidad profunda de los senos espirituales no es natural, no la trajeron esos hombres del vientre de su madre: fue, antes al contrario, su conquista y su labor» ${ }^{113}$. En ese caso, la Universidad no puede consistir en pasar lista o deambular por el campus. Hay que hacer ciencia y pensar y vivir una ética.

En cuanto a Unamuno, según Ortega, parece haber preferido la sombra a las claridades - como el mozo de la barahunda-, san Juan de la Cruz a Descartes: «Los único triste del caso es que a D. Miguel, el energúmeno, le consta que sin Descartes nos quedaríamos a oscuras y nada veríamos, y menos que nada el pardo sayal de Juan de Yepes» ${ }^{114}$.

En cualquier caso unos nombres como Cajal o Menéndez Pidal, según confirma a Ortega Américo Castro, no bastan para «cubrir con la prez de un nombre ilustre el nefando pecado de la felonía intelectual» ${ }^{115}$. Es necesario pasar de las cuestiones y discusiones personales a la realidad de la verdad en «la moral, la ciencia, el arte, la religión, la política» ${ }^{116}$. Los intelectuales deben intervenir en el futuro y el porvenir histórico y seguir el ejemplo de Renan que llevaba en sus estudios de Antiguo y Nuevo Testamento Dios a la historia y la historia a Dios: «Renan miraba todas las cosas bajo la especie de lo histórico, mas cómo para él lo histórico es lo divino, lo que tiene en sí mismo valor

110. I 122; «Sobre una apología de la inexactitud», Faro (20.9.1908).

111. Ibid.

112. I 125; «Una fiesta de paz» El Imparcial (5.8.1909).

113. I 124; «Una fiesta de paz» El Imparcial (5.8.1909).

114. I 129; «Unamuno y Europa, Fábula, El Imparcial (27.9.1909).

115. I 130; «Unamuno y Europa, Fábula, El Imparcial (27.9.1909).

116. I 131; «Unamuno y Europa, Fábula, El Imparcial (27.9.1909). 
y su perenne justificación, su filosofía de la historia es, en realidad, una teología» ${ }^{117}$.

Para Renan Dios es la categoría de la dignidad humana, concentra cuanto de mejor hay en el hombre y éste le llama Justicia, Sabiduría, Fortaleza. La reflexión destruye esas personificaciones y las reduce a fuerzas del espíritu humano y sus actos de justicia, de verdad y de bien: «Dios queda disuelto en la historia de la humanidad; es inmanente al hombre: es, en cierto modo, el hombre mismo padeciendo y esforzándose en servicio de lo ideal. Dios, en una palabra, es la cultura. 'Tú eres mi mejor yo', canta una vez Shelley a la mujer que inspira sus canciones; podría decirse que Dios es el conjunto de las acciones mejores que han cumplido los hombres: el Partenón y el Evangelio, Don Quijote y la mecánica de Newton, la Revolución francesa y la «Historia Romana» de Mommsen, las cooperativas de consumo y el régimen parlamentario. Dios es lo mejor del hombre, lo que le enorgullece, lo que intensifica su energía espiritual, la herencia científica y moral acumulada lentamente en la historia» ${ }^{118}$.

Esa cosecha hay que asimilarla. No se trata del panteísmo sino del respeto y la memoria que es donde germinan las virtudes teologales de la fe y la esperanza y el amor. La temporalidad es ahora el sacramento, signo y realidad visible de la profunda realidad invisible, de la eternidad. Por eso las realidades del tiempo «representan las inquietudes de un Dios que se está haciendo. $L a$ historia es la embriogenia de Dios, y por tanto, una especie de teología; recordar, hacer memoria del pasado, se transforma de este modo en un misterio religioso, y al Cuerpo de archiveros compete hoy las funciones encomendadas a los párrocos y sus coadjutores. La Filosofía, según Renan, «'tiene curas de alma'»"19. Ya había dicho Spinoza que 'todo es Dios', toda la Naturaleza, cuanto existe es 'una limitación de Dios'. «En este sentido no podía Renan ser. panteísta. El siglo XVIII, el siglo de Leibniz, Newton, Hume y Kant, ha hecho imposible el trato mano a mano con nada que, siendo real, pretenda ser ilimitado y absoluto. Hoy sólo pueden hacer esto los místicos, que son, por decirlo así, apaches de la divina sustancia, gente que atraca en la soledad de un éxtasis al buen Dios transeúnte» ${ }^{120}$.

Dios es para Renan la «categoría del ideal», y España debe ponerse a la altura de la cultura europea con una cultura del pueblo y de ideales, con un examen de conciencia nacional, con una especie de sacerdocio de la edu-

117. I 134; «La teología de Renan», Europa (20.2.1910).

118. I 135; «La teología de Renan», Europa (20.2.1910).

119. I 136; "La teología de Renan», Europa (20.2.1910). Subrayado nuestro.

120. I 134; «La teología de Renan», Europa (20.2.1910). Subrayado nuestro. 
cación ${ }^{121}$, que renueve la sensibilidad para «dotarla de intimidad» ${ }^{122}$. No hay otros genios que los que "dan matrices vivas de cultura» ${ }^{123}$. Por eso el genio tiene algo de divino y éste y la cultura tienen una proximidad suma hasta poderse decir que 'Dios es la cultura'.

Mientras Europa es el respeto y la colaboración, la Universidad troglodita española perpetúa la barbarie de la 'desespiritualización' y una inmoralidad de cómplices. No basta decir que se olvide a Balmes, hay que construir la patria viva del futuro ${ }^{124}$. Europa no es sólo una negación, es la agresión constante y metódica al achabacanamiento, el fermento renovador de la España posible: Un método para rehacer la España invertebrada como Descartes empleó la duda metódica «para fundamentar la certidumbre» ${ }^{125}$.

España necesita cultura y cultivo. «Somos cisterna y debiéramos ser manantial» ${ }^{126}$, fuente de sustancias humanas de significado universal en «mecánica, economía, democracia y emociones trascendentes» ${ }^{127}$. Hay que descubrir en silencio «una nueva alma para España, una alta espiritualidad continental» ${ }^{128}$. En España, según el personaje orteguiano, Rubín de Cendoya, místico y español, cada uno ha de hacer de todo. Hay que «dedicarnos todos a la política» ${ }^{129}$. No es suficiente la sinceridad, la espontaheidad del puñetazo; eso es el orangután no el hombre. El hombre es ser de convención; sólo así el parlamento es una valla frente a la violencia.

España necesita Veracidad pero de esa «¡Divina Veracidad, virtud activa, que nos mueves, no tanto a decir la verdad como a buscarla antes de decirla!» ${ }^{130}$. No basta decir y hacer lo que es natural, porque lo natural no pasa de lo sexual, mientras que la «cultura es frente a la natura el reino de lo conveniente y de lo convenido» ${ }^{131}$. Así se llama Convención a la institución suprema de la Revolución francesa. La espontaneidad orgánica no sirve. Por eso la necesidad de parlamentos, aunque las 'mejores cosas humanas' se reducen a ser las menos malas. La pura originalidad es con frecuencia simple error y frivolidad.

Es necesario pasar de la guerra al trabajo, del guerrero al ingeniero. El verdadero héroe es el de la política hidráulica y cereal, el héroe del progreso,

121. I 139; «¿Una exposición Zuloaga?», El Imparcial (21.4.1910).

122. I 140; «¿Unä exposición Zuloaga?», El Impararcial (21.4.1910).

123. Ibid.

124. I 143-144; «Nueva Revista», El Imparcial (27.4.1910).

125. I 144; «Nueva Revista», El Imparcial (27.4.1910).

126. I 145; «Nueva Revista», El Imparcial (27.4.1910).

127. Ibid.

128. I 146; «La epopeya castellana, por Ramón Menéndez Pidal», Europa (22.5.1910).

129. I 147; «Planeta sitibundo», I, El Imparcial (25.7.1910).

130. I 148; «Planeta sitibundo», I, El Imparcial (25.7.1910).

131. Ibid. 
no el simple salvaje: la experiencia del dolor debe hacer a los héroes discretos para una nueva vida en paz en el nuevo planeta español. Allí: «Habrá canciones rituales al agua madre, que descenderá eternamente grácil por los magníficos estuarios; habrá una literatura que se inspirará en los altos canales henchidos de la primavera, y otra más elegíaca a los canales vacíos invernales. Habrá también una religión. ¿Cómo no? Melquiades Alvarez nos ha dicho en el salón de sesiones hace un momento que el planeta no pueda vivir sin religión. Sin agua tampoco, ilustre D. Melquiades, habremos de decirle nosotros. En Marte hay la religión del agua, como en la Tierra la del espíritu que se movía sobre el agua» ${ }^{132}$.

Hay que hacer, dice Ortega, una política planetaria; una filosofía de la Historia que tiene que «comenzar con el cielo», y, a la vez, ha de darle a la historia un carácter «telúrico» ${ }^{133}$. Igualmente se deben evitar la discusiones vanas. Por ejemplo, la disputa de Campoamor y Valera no enseña nada de metafísica ni de poesía, solamente revela la nulidad «del alma colectiva de la época en que se cometió» ${ }^{134}$. Esto no invalida toda narración, pues, como dice Goethe, se cuenta la leyenda para que se descubra la verdad cuando ocurre que «nada hay como haber tratado a un hombre ilustre, para no saber quién es» ${ }^{135}$. Y hay que contar su leyenda para que se le conozca de verdad. Describir es, siempre, construir, inventar lo mejor y fundamentar. Así es en la historia, en la naturaleza y en la vida de un pueblo. «Hay en la historia del cristianismo un caso espléndido, que muestra lo que vale no haber visto las cosas y hallarse sometido a inventarlas, a pensarlas y a construirlas racionalmente. San Pablo no conoció a Jesús, no vio a Jesús; de segunda y tercera mano recibió noticias de los actos de su existencia, de sus operaciones taumatúrgicas y de sus sencillas palabras. Cuando haciendo vía a Damasco un vuelco de su alma candente le trajo a la fe de Jesús, ¿qué podía hacer su espíritu poderoso desparramado por la serie de noticias que sobre él poseía? San Pablo necesitó recoger aquéllos como miembros dispersos del divinal sujeto, y reconstruir con ellos la figura de Jesús. Como no lo había visto, necesitaba figurárselo. Los demás apóstoles con tornar los ojos a su propia memoria, les bastaba para ver al Jesús real que caminaba entre sus recuerdos benigno y dulcifluo. A san Pablo, por el contrario, no se le presentaba espontáneamente, tuvo él que hacérselo, tuvo que pensarlo. De recordar a Jesús como san Pedro, a pensar a Jesús como san Pablo, va nada menos que la teología. San Pablo fue el primer

132. I 152; «Planeta sitibundo», II, El Imparcial (1.8.1910).

133. I 153; «Planeta sitibundo», II, El Imparcial (1.8.1910).

134. I 156; «Una polémica», I, El Imparcial (19.9.1910).

135. I 157; «Una polémica», I, El Imparcial (19.9.1910). 
teólogo; es decir, el primer hombre que del Jesús real, concreto, individualizado, habitante de tal pueblo, con acento y costumbres genuinas, hizo un Jesús posible, racional, apto, por tanto, para que los hombres todos, y no sólo los judíos pudieran ingresar en la nueva fe. En términos filosóficos, san Pablo objetiva a Jesús. Se me dirá que, en el camino de Damasco, Jesús se reveló a san Pablo. Cierto; camino de Damasco llegó a madurar la labor reconstructiva, que tiempo hacía ocupaba la mente del apóstol, y allá, cerca de Dareya, a la hora del mediodía, consiguió elevar los datos sueltos a la unidad de un carácter, y, súbitamente, se le reveló Jesús en la perfección de su ser. ¿Qué dignidad añade a la revelación el hecho físico de ver una luz entre dos cirrocúmulos?» ${ }^{136}$.

Hay que reconstruir nuestro pasado para tener un futuro. No se puede nivelar todo ni igualarlo masivamente, eso es un 'positivismo cazurro'. La misma crítica debe ser voluntad de mejorar las cosas, en otro caso no es sino vulgarizar e insensibilizar, ante lo diferente, y falta de sabiduría ante lo realmente valioso, pues «donde todo vale lo mismo, nada tiene valor» ${ }^{137}$. Precisamente Valera ha sido el exponente entre los celtibéricos de la «democracia como nivelación universal» ${ }^{138}: \mathrm{La}$ popularidad de la ordinariez, que todo lo iguala, porque lo inutiliza para lo mejor. Así, la bondad se torna casual y no genial. La metafísica tampoco vale nada. Valera cree, por eso mismo, que la metafísica es una religión más clarificada y un lujo de ricos, inútil para la humanidad. El que no cree en nada hace un crítica niveladora. Es un positivismo 'igualador e infecundo', por completo inverecundo, que lleva el escepticismo sobre todo. Por eso, Valera no tiene inconveniente en escribir: 'Kant no sé yo lo que quiso, ni sé si él lo sabía'. ¿Eh, maestro glorioso, insigne celtíbero!, ¿qué es eso? Yo no tengo para qué salir a la defensa de Kant; pero el instinto de conservación me invita a protestar de esas palabras; porque, isanto Dios!, si Kant no supo lo que se decía, ¿qué hizo Valera toda su vida? Y si Kant y Valera se dedicaron a la extravagancia y la indiscreción, ¿qué haremos nosotros, mortales de estructura incorrecta y sólita?» ${ }^{139}$.

El celtibérico suele creer que la dignidad humana es incompatible con la suya, y sin embargo: «Sólo porque Platón, Cervantes y san Francisco de Asís vivieron, llegamos a creer que nuestro linaje no es idiota ni egoísta» ${ }^{140}$. Eso es europeización y universalismo auténtico. Julio Cejador, que debiera estar en la Universidad, según Ortega, disiente de éste respecto a Costa y la europeiza-

136. I 157-158; «Una polémica», I, El Imparcial (19.9.1910).

137. I 161; «Una polémica», II, El Imparcial (6.10.1910).

138. Ibid.

139. I 162; «Una polémica», II, El Imparcial (6.10.1910).

140. I 163; «Una polémica», II, El Imparcial (6.10.1910). 
ción. Le falta a Cejador altruísmo intelectual, receptividad y capacidad de transustanciarse en el otro para comprenderle y, según Ortega, Cejador «no sabe bien de qué estamos hablando. Pretende que volvamos a contraponer europeísmo y españolismo, censura a Maeztu por muy aficionado al extranjero y, al través de Maeztu - ¡D. Julio es una fardida lanza que atraviesa a pares los enemigos! - me cuelga a mí algunas opiniones extravagantes. Vamos a intentar deshacer el equívoco" ${ }^{141}$.

No se debe oponer reconstitución y europeización como parece ver Cejador en Maeztu. Ortega dice que nunca lo ha opuesto y advierte de paso que el pensamiento de los hombres no se caza a lazo. Costa se educa en Herder, Schelling y Hegel: "Queríase ver en la historia el campo de la experiencia metafísica, el lugar donde daba sus revelaciones el Espíritu universal. Estas revelaciones son lo que se llamó espíritu de los pueblos. En el siglo XVIII había la razón raciocinante verificando una nivelación de todas las diferencias en pro de una unidad radical: la idea del progreso, la declaración del poder hegemónico de la ciencia, sublime a toda fe - ila fe es el pensamiento oscuro; tal vez un mal pensamiento! - hicieron posible la noción de Humanidad, de ese conjunto de valores normales a que todos los hombres pueden aspirar. Nada de este mundo ni del otro podrá movernos a perder esta clara conquista del siglo luciferino, del siglo claro y esčlarecedor. No obstante; ocurre esta sospecha; cuando buscamos en el paisaje un altozano, no queremos sino ver mejor el valle» ${ }^{142}$. Siempre hay una dialéctica entre unidad y diferencia, entre lo humano y su más allá. El siglo XVIII, unificador y clarificador necesita del complemento de lo diferencial, romántico, lo individual de los pueblos y su realidad más profunda. Es la dialéctica de lo racional y lo irracional, de la minoría reflexiva y la muchedumbre espontánea. Pero «los románticos se dirigen con preferencia a ésta, en cuya ingenuidad e irreflexión creen hallar una mayor energía originaria, pura de intenciones niveladoras, una mayor proximidad a los poderes elementales del universo. No de otro modo, según el Nuevo Testamento, Dios prefiere a los niños, a los enfermos, a los aldeanos para manifestarse. Los románticos llaman pueblo propiamente a la porción irreflexiva del pueblo» ${ }^{143}$.

Con la excepción de los krausistas, los españoles tomaron todo de fuera sin meditarlo. Así Costa acepta las teorías del 'carácter metafísico irrompible' y su justificación absoluta del pueblo ${ }^{144}$, que son las de Renan, Taine y otros por el estilo. El programa de Costa es «el símbolo del pensador romántico,

141. I 165; «Observaciones», El Imparcial (25.3.1911).

142. I 166; «Observaciones», El Imparcial (25.3.1911).

143. I 167; «Observaciones», El Imparcial (25.3.1911).

144. Ibid. 
una profética fisionomía que ungida de fervor histórico místico conjura sobre la ancha tierra patria el espíritu popular, el Volkgeist que pensaron Schelling y Hegel, el alma de la raza sumida en su sopor, cuatro veces centenario. Y claro está, no acudió, porque el espíritu popular no existe más que en los libros de una filosofía superada, supuesto que fuera alguna vez bien entendido» ${ }^{145}$.

Unamuno, le parece a Ortega, al respecto, más discípulo de Miguel de Molinos que de Miguel de Cervantes ${ }^{146}$. Su desencanto es contrario al utopismo de algunos que parecen dormidos y a los que despierta y remueve. España, entre tanto, se tibetaniza cada vez más, en vez de europeizar África. Ortega cada vez duda menos de la necesidad de resucitar «el sacramento moderno de la investigación $»{ }^{147}$. Más cultura y menos guerra, más políticos informados y menos fanatismo religioso. Ortega es un realista como es realista el español; mientras, nuestras catedrales góticas como un torbellino arrebatador señalan hacia el altísimo infinito como hacia «una nada donde se hallara fermentando todo" ${ }^{148}$. Donde concluye el español, realista y material, comienza el hombre que aspira a lo trascendente e infinito, que como la catedral gótica aspira conmovido a capturar «la terrible bestia rauda del infinito.

Sin embargo, estas conmociones son oportunas; aprendemos en ellas nuestra limitación, es decir, nuestro destino. Con la limitación que ha puesto en nuestros nervios una herencia secular, aprendemos la existencia de otros universos espirituales que nos limitan, en cuyo interior no podemos penetrar, pero que resistiendo a nuestra presión nos revelan que están ahí, que empiezan ahí donde nosotros acabamos. De esta manera, a fuerza de tropezones con no sospechados mundos colindantes, aprendemos nuestro lugar en el planeta y fijamos los confines de nuestro ámbito espiritual, que en la primera mocedad aspiraba a henchir el universo» ${ }^{149}$.

El español necesita serenarse tanto del pathos materialista del Sur como del trascendentalismo del Norte pues ambos son inestables y excéntricos. Esa serenidad la tiene la catedral de Sigüenza «toda ella oliveña y rosa, me parecía una nave que sobre aquel mar castizo venía a traerme la tradición religiosa de mi raza condensada en el viril de su tabernáculo» ${ }^{150}$. En ella, religión y poesía son afirmadoras de este mundo y el «otro mundo en ellas se hace presente de una manera humilde y simple, como rayico de sol que baja a iluminar las cosas mismas de este mundo y las acaricia y las hermosea y pone en ellas iridis-

145. I 169; «Observaciones», El Imparcial (25.3.1911).

146. I 171; «Libros de andar y ver» I, El Imparcial (31.5.1911).

147. I 172; «Libros de andar y ver» I, El Imparcial (31.5.1911).

148. I 187; "Arte de este mundo y del otro», I, El Imparcial (24.7.1911).

149. I 187-188; «Arte de este mundo y del otro», I, El Imparcial (24.7.1911).

150. I 188; «Arte de este mundo y del otro», I, El Imparcial (24.7.1911). 
cencias y un poco de esplendor. Uno y otro, templo y cantar, se contentan circunscribiendo un trozo de vida. La religión y la poesía no pretenden ellas suplantar esa vida, sino que la sirven y diaconizan. ¿No es esto discreto? La religión y la poesía son para la vida» ${ }^{151}$.

En cambio en el gótico, la religión se ha hecho orgullosa, niega la vida y este mundo por otro que soberbiamente se imagina. El gótico es excesivo en ascendencia y trascendencia; aunque cuando el arte es pleno, el equilibrio maravilla: «hay realmente iglesias dotadas de tal empuje pneumático ascendente, que las juzgamos capaces de ser asumptas al cielo, aun llevando a la rastra todo el peso de un cabildo gravitante» ${ }^{152}$. Es así como la arquitectura es capaz de mostrarnos «lo que realmente haya de verecundo, de profundamete humano y significativo en el misticismo gótico» ${ }^{153}$.

La pesadumbre románica nos muestra más el valor firme, sólido, de nuestra tierra; pero tiene, junto a sus propias ventajas, sombras y oscuridades que metidas en la religión hacen recelar, a Ortega, hombre de claridades: «ese misticismo, esa suplantación de este mundo por otro me pone en sospechas. Unido a un gran respeto y a un fervor hacia la idea religiosa, hay en mí una suspicacia y una antipatía radicales hacia el misticismo, hacia el temperamento confusionario, que me impide encontrarle justificación dondequiera se presenta. Siempre me parece descubrir en él la intervención de la chifladura, o de la mistificación» ${ }^{154}$.

El arte es una explicación, entre el hombre y el mundo, del sentimiento cósmico y del sentimiento religioso, «una operación espiritual tan necesaria como la reacción religiosa o la reacción científica» ${ }^{155}$. Pero la iconoclastia hace imposible tanto la estética como la religiosidad o la vida. Es el primitivo que resuelve las cosas, mecánicamente, apresuradamente a golpes.

Vivimos hoy entre antítesis «la religión se opone a la ciencia, la virtud al placer, la sensibilidad fina y estudiada al buen vivir espontáneo, la idea a la mujer, el arte al pensamiento...» ${ }^{156}$.

Pero la vida sólo es perfecta si aspira a la plenitud sin mutilación: «Ahora bien: las gentes suelen mostrarse demasiado presurosas en decidirse por lo mejor: olvidan que cada acto de preferencia abre, a la vez, una oquedad en nuestra alma. No, no prefiramos; mejor dicho, prefiramos no preferir. No renun-

151. I 188-189; «Arte de este mundo y del otro», I, El Imparcial (24.7.1911). «La vida es el texto eterno, la retama ardiendo al borde del camino donde Dios da sus voces»: I 357, MQ (1914).

152. I 189; «Arte de este mundo y del otro», I, El Imparcial (24.7.1911).

153. Ibid.

154. Ibid.

155. I 191; «Arte de este mundo y del otro», I, El Imparcial (24.7.1911).

156. II 45-46; E I (1916), «Tierras de Castilla», II (1911). 
ciemos de buen ánimo a gozar de lo uno y de lo otro: religión y ciencia, virtud y placer, cielo y tierra... Cierto que hasta ahora no se han resuelto las antítesis; pero cada hombre debe pensar que es él el llamado a resolverlas» ${ }^{157}$.

Con frecuencia se ha presentado la religión como la relación a lo absoluto por el espanto y el 'miedo a la realidad '. En cambio lo divino es lo armonioso, lo proporcionado, confirmado y repetido 'en las formas infinitas de la vitalidad universal', con una cierta falta de interés «para ese 'más allá' que limita la porción del mundo acotado por nuestra razón» ${ }^{158}$. La ciencia urbaniza el caos de este mundo concreto, la verdadera religión ordena el asombro y el mundo que nos excede, pues como dice Worringer en continuidad con Schopenhauer, «lo que el hombre clásico llamaba Naturaleza es sólo el velo de Maia prendido sobre una incognoscible realidad trasmundana» ${ }^{159}$. Y más allá del desdén cristiano o la abstracción griega o del miedo primitivo hay «una postura genuina ante el mundo, una metafísica que no es la abstracción del indoeuropeo, ni el naturalismo racionalista clásico, ni el misticismo oriental» ${ }^{160}$. Es el «realismo agresivo $y$-vencedor» de los artistas españoles que se encarna incluso en los vencidos. Es Velázquez que pinta el aire con quien nadie contaba; o Azorín y Unamuno que salvan lo vulgar y las hermanas cosas. Es el hombre español y su propio realismo: «Cuando Murillo pinta junto a la Sagrada Familia un puchero, diríase que se prefiere la grosera realidad de éste a toda la corte celestial; sin espiritualizarlo lo mete en el cielo con su olor mezquino de olla recalentada y grasienta» ${ }^{161}$. Esa agresión trascendentalista y afirmativa de lo sencillo y pequeño y divino, eso es nuestro realismo español. Dios anda entre los pucheros diría santa Teresa. Y hay que hacer una religión que salve a los españoles de sus males para que dejen de llamar 'catolicismo' a sus vicios seculares, personales $0 / y$ estructurales.

En resumen, Ortega se plantea desde un principio los problemas básicos de su pensamiento que son los de su circunstancia y que, en relación a la religión, podrían significarse así:

1. Hay que afirmar el misterio de la vida generosa y fuerte, vivida con entereza, bravura humana y religiosa sabiduría para hacer una España nueva y vital.

2. Hay que optar por la sinceridad del héroe honrado, y noble, frente a la chabacanería del ambiente y la deserción general.

157. II 46; E I (1916), «Tierras de Castilla», II (1911).

158. I 197; «Arte de este mundo y del otro», V, El Imparcial (13.8.1911).

159. I 198; «Arte de este mundo y del otro», VI, El Imparcial (13.8.1911).

160. I 199; "Arte de este mundo y del otro», VI, El Imparcial (13.8.1911).

161. I 199-200; «Arte de este mundo y del otro», VII, El Imparcial (13.8.1911). 
3. Es preciso crear nuevos valores, que valgan, frente a la moralina oficial y el catolicismo etéreo y abstracto. Ética y nivel.

4. Se debe tomar una postura decidida frente a la injusticia y el desorden de la masa, sea esta aristocrática o popular. Lo mismo si la fomentan los dominadores que si se le da un aire religioso.

5. Hay que huir, como del diablo, del intelectual filisteo, despreocupado del sufrimiento humano que es a su vez el dolor divino. Lo mismo hay que alejarse del misticismo nebuloso y confuso; y arrinconar el planteamiento volcánico de la vida. Eso no excluye ni al místico como centinela de la humanidad ni al que busca, como la Revolución francesa, pero sin violencia, la fraternidad, la libertad y la igualdad.

6. Es preciso esforzarse por despertar España a la ciencia para alejar el alma española, embelesada, frecuentemente, con el canto de los canarios, del dogmatismo y la retórica. Hay que visitar con la esperanza y llamar a la resurrección a nuestro pueblo que sufre sin cesar - obrero o agricultor - bajo la desidia oficial.

7. Entre tanto dolor, Ortega pensador, se presenta también como un Rubín de Cendoya, místico español que siente el ansia infinita de los mortales y, en especial, la angustia del campo español vendido a la muerte por treinta dineros de plata.

8. Hay que volver al hombre; saber estar, sobre todo en los tiempos grises y difíciles que Dios impone a la historia.

9. Es necesario retornar a la aventura del ideal, dejar el 'Dios de los muertos' e intentar ser, realmente, mejores como el super-hombre tan humano y tan divino a la vez.

10. España es hoy un fantasma, sin alma ni sustancia, y necesita una resurrección, una nueva cultura total alejada de la anarquía secular.

11. España está, por ahora, viuda del alma, sin dirección espiritual ni moral, sin ciencia ni bienestar material. En ella la confusión y el equívoco se han convertido en una industria nacional...

12. Hay que hacer claridad, una cultura con nivel adecuado a la altura de Europa, cada cual desde su oficio, más allá del pragmatismo ramplón y de la religión ayuna de ideales nobles; hay que dar de lado a la religión de los espíritus inactivos, paralíticos, incapaces de descubrir al hombre y al mundo en su misterio inefable y exigente.

13. Es necesario dar de lado a las peleas personales, tan frecuentes entre los españoles. Dedicarse, por el contrario, a construir una ciencia, una ética, un arte, una política y una religión nuevas que incidan en nuestra historia concreta. Nada de materialismos cerrados ni de idealismos panteístas. Hay que modernizar la sociedad y la religión. 
14. Hay que crear una nueva intimidad nacional pues la que había se ha perdido. Una nueva España, con alma veraz. Una nueva cultura, nueva economía, nueva política, nueva religión. Sin discusiones vanas, hay que inventar a fondo en religión como en convivencia. Tenemos que tomar el camino de la humanidad. No podemos seguir siendo celtíberos eternamente aislados y tibetanizados. Es necesario ser profundamente humanos, si queremos ser algo más.

15. Hoy día es preciso huir de los extremismos; del idealismo del Norte y del materialismo del Sur, debemos salir hacia la serenidad religiosa, al respeto profundo de la realidad, del mundo, del hombre, de lo divino para que reine esa religión que confirma la vida y supera la muerte. Esa religión que nos enseña la piedra viva de la catedral de Sigüenza. Nada de materialismos trasnochados, ni de religiones mistificantes y menos de iconoclastias.

16. Hay que aspirar a todo, a la ciencia y a la religión, al gozo y a la virtud, al cielo y a la tierra... a la nobleza del pueblo. Y que cada uno se empeñe en resolver esas paradojas como su propio problema... $\mathrm{Y}$, en cualquier caso, sean las paradojas solubles o no, queremos este mundo y el otro, la olla de la cocina y el cielo del más allá, como lo querían nuestro Velázquez y nuestro Murillo. Pues todo eso es el realismo español, el nuestro, según Ortega. 


\section{DIOS A LA VISTA Y DIOS ESCONDIDO}

\subsection{DIOS PRESENTE EN LA SOLEDAD HUMANA}

En noviembre de 1926 Ortega sorprende a sus lectores con un escrito titulatlo «Dios a la vista». En él afirma que como la Tierra se aleja y se acerca al Sol periódicamente, el hombre se aproxima o huye de Dios de un modo semejante: «Algo parecido acontece en la órbita de la historia con la mente respecto a Dios. Hay épocas de odium Dei, de gran fuga lejos de lo divino, en que esta enorme montaña de Dios llega casi a desaparecer del horizonte. Pero al cabo vienen sazones en que súbitamente, con la gracia intacta de una costa virgen, emerge a sotavento el acantilado de la divinidad. La hora de ahora es de este linaje, y procede gritar desde la cofa: ¡Dios a la vista!» ${ }^{1}$.

Ortega descarta la beatería, de este proceso, e incluso la religiosidad, principalmente cultural, para reivindicar un Dios laico. Explica el proceso descrito arriba porque en cada época se atiende de modo especial una dimensión del universo mientras que a la vez se desatienden otros aspectos del mismo. La época anterior era, según Ortega, demasiado agnóstica, se desentendía del ultramundo y se reducía a un panorama mutilado de este mundo sin fundamento: «Porque 'este mundo' es lo que queda del Universo cuando le hemos extirpado todo lo fundamental; por tanto, un mundo sin fundamento, sin asiento, sin cimiento, islote que flota a la deriva sobre un misterioso elemento.

El hombre agnóstico es un órgano de percepción acomodado exclusivamente a lo inmediato" ${ }^{2}$.

Este proceso es la reacción excesiva a una comprensión negativa del mundo tal como se produce en Grecia y en algunos sectores del cristianismo que llegan a despreciar la creación para exaltar la redención cristiana. Se tiene como asco de las criaturas. Y se cae en una falsa glorificación del Creador.

Ante tal situación Ortega propone una línea intermedia fronteriza entre

1. Ortega y Gasset, J., Obras completas, II, Alianza y Revista de Occidente, Madrid 1983, 493; E VI (1927).

2. II 495. Cfr. también BoERo VARGAS, M., Un breve ensayo de Ortega en 'El Espectador': 'Dios a la vista' en Cuadernos Hispanoamericanos 403-405 (1984) 191-194. 
ambos mundos: «Esa línea en que 'este mundo' termina, le pertenece, y es, por tanto, de carácter 'positivo'. Mas a la vez, en esa línea comienza el ultramundo, y es, en consecuencia, trascendente. Todas las ciencias particulares, por necesidad de su interna economía, se ven hoy apretadas contra esa línea de sus propios problemas últimos, que son, al mismo tiempo, los primeros de la gran ciencia de Dios» ${ }^{3}$. Aún si se admite que la fórmula es «hiperbólica, y un tanto irónica» ${ }^{4}$ no conviene olvidar que hay una nueva marejada metafísica por esta época. Personalmente, el acantilado de Dios en su aparición magnífica y repentina, me hace recordar la conocida experiencia de Nietzsche con todas sus preocupaciones: pongamos a Dios compuertas no sea que nos anegue. Esta nueva presencia de Dios en la experiencia de Europa, en torno a los años de 1920, la afirma Ortega en otras dos ocasiones con más detalle, y se vincula expresamente a la teología dialéctica de Gogarten y K. Barth ${ }^{5}$. Todo el asunto está muy vinculado a la ciudad de Marburgo donde Ortega conserva buenos amigos. Concretamente Natorp está muy especialmente presente en este nuevo despertar de la teología dialéctica. En la facultad de teología profesa el padre y maestro de la escuela exegética radical Rudolf Bultmann. «¿Será exacto si digo que el primer autor español que se percata de la profunda significación de esta corriente exegética es Ortega, que dedica un largo artículo a comentarla, bajo el título: «La forma como método histórico»? ${ }^{6}$. Veremos también aparecer otros profesores de teología en Marburgo como W. Herrman, influyente en Unamuno, R. Otto, A. Harnack que llega a ser presidente del Instituto Max Planck y expresa así la influencia cultural de la teología en esa época. El romanista Leo Spitzer en su discurso «¿Qué es Marburgo?» puso al primer hombre del que cabía decir «Esto es Marburgo» a Rudolf Bultmann. Y después, una gran lista de filósofos y teólogos; como dice muy bien Olegario G. de Cardedal: «Este rumor de fondo está sonando siempre en los libros de Ortega. Y si

3. II 496.

4. Cereżo Galán, P., La voluntad de aventura, Ariel, Barcelona 1984, 106.

5. VIl 343; QF (1929): En la nota 1 de dicha página dice: «Me complace ver el despertar de un nuevo movimiento teológico en Alemania -en la obra de Karl Barth - el cual acentúa que teología es theologéin (tipos en griego)-: hablar de Dios, no callar sobre Dios»: Ibid.

«Yo creo que el alma europea se halla próxima a una nueva experiencia de Dios, a nuevas averiguaciones sobre esa realidad, la más importante de todas». En 1920 escribe Max Scheler su famosa obra, Von Ewigen im Menschen, Franke, Bern ${ }^{4}$ 1954. También en 1920, con un artículo suyo saca Gogarten a la luz la teología dialéctica. Natorp está presente en la primera conferencia de Gogarten sobre el tema. Barth no hace juramento al Führer y por eso perdió la cátedra en 1935: Cfr. Zahrnt, H., A vueltas con Dios, trad. castellana de A. Alemany, Hechos y Dichos, Zaragoza 1972, 62ss. Ortega cree que no se puede permanecer sordo al clamor de lo divino: II 608; «El origen deportivo del Estado» (1924).

6. GonZÁlez de CARdedAl, O., Ortega y Gasset. Memoria agradecida en el 25 aniversario, en El Ciervo 356 (1980) 31. Cfr. del mismo autor: ID., José Ortega y Gasset: La altura de Europa, en El poder y la conciencia, Espasa Calpe, Madrid 1984, 125-164. 
ensanchamos la mirada vemos las figuras de M. Hiedegger, M. Scheler, R. Guardini, E. Przywara...» ?.

Antes incluso de esta marejada metafísica y religiosa Ortega advierte que lo importante no son las verdades sabidas que adquieren una costra utilitaria, sino que lo importante es la verdad como alétheia y apocalipsis-revelación y la pedagogía de la alusión, donde más allá de las realidades del primero y del segundo plano están las realidades sugeridas, más profundas. Pero estas realidades más altas no caen sobre nosotros de repente, son pudorosas y hay que esforzarse por ellas. No nos invaden bárbaramente. Hay que tender hacia ellas: «Cuando dice el hombre de mucha fe que ve a Dios en la campiña florecida y en la faz combada de la noche, no se expresa más metafóricamente que si hablara de haber visto una naranja. Si no hubiera más que un ver pasivo quedaría el mundo reducido a un caos de puntos luminosos. Pero hay sobre el pasivo ver un ver activo, que interpreta viendo y ve interpretando; un ver que es mirar. Platón supo hallar para estas visiones que son miradas una palabtra divina: las llamó ideas. Pues bien, la tercera dimensión de la naranja no es más que una idea, y Dios es la última dimensión de la campiña.

No hay en esto mayor cantidad de misticismo que cuando decimos estar viendo un color desteñido ${ }^{8}$.

Por una parte nuestro autor cree que el conocimiento es siempre una complementación de la realidad. Por otra, muestra que hay en esa realidad algo más profundo que nunca acabamos de descubrir. Ve la razón de Heráclito cuando decía que la realidad tiende a ocultarse. Ahora bien: «La cifra máxima en este poder de clandestinidad corresponde a Dios y por ello su advocación más filosófica debiera ser la de Deus absconditus. Si el escolasticismo hubiera sido más auténtica filosofía se habría preguntado más perentoriamente por qué Dios se esconde tanto en vez de contentarse con atribuirlo a su infinitud y a su exuberancia» ${ }^{9}$.

Dios, por ser la realidad suprema, es también la más escondida y oculta. Y su presencia parece una ausencia. En genial expresión, Ortega afirma que Dios «brilla por su ausencia» y que ese es su modo peculiar de estar presente. De este modo: «Dios es el que es precisamente como ausente, es el inmenso ausente que en todo presente brilla - brilla por su ausencia-, y su papel en ese citarlo como testigo que es el juramento, consiste en dejarnos solos con la realidad de las cosas, de modo que entre estas y nosotros no hay nada ni nadie

7. ID., Orlega y Gasset. Memoria agradecida en el 25 aniversario, en El Ciervo 356 (1980) 31.

8. I 336; MQ (1914) «Trasmundos».

9. VII 13-14; «Prospecto del Instituto de Humanidades» (1948). 
que las vele, cubra, finja, ni oculte; y el no haber nada entre ellas y nosotros, eso es la verdad. El maestro Eckehart (sic) -el más genial de los místicos europeos- llama por eso a Dios 'el silente desierto que es Dios'» ${ }^{10}$. Y quién quiera descubrirlo habrá de hacer una dura crítica de la vida convencional ante el tribunal inexorable de la soledad.

Solamente en la soledad encuentra el hombre su auténtico ser. En ella encuentra también el cristiano su verdadero Dios: «No hay más que esa doble realidad: Dios y el alma -y como conocimiento es siempre para el cristiano conocimiento de lo real, el conocimiento ejemplar será el de Dios y el alma. Así san Agustín: Deum et animam scire cupio. Nihilne plus? Nihil omnino. No es casual que sea san Agùstín el primer pensador que entrevé el hecho de la conciencia y del ser como intimidad, y tampoco lo es que sea el primero en caer en aquello de que no se puede dudar de que se duda. Es curioso que el fundador de la ideología cristiana y el fundador de la filosofía moderna coincidan en toda su primera línea»"

La llamada agustiniana a la interioridad es clave también para la modernidad, según Ortega, y es en ese «Noli foras ire, in te ipsum redi: in interiori homine habitat veritas», donde hay que buscar el verdadero conocimiento y al Dios que está en 'el fondo del alma' según santa Teresa. «El Dios cristiano, por lo visto, es trascendente al mundo, pero inmanente al 'fondo del alma' ¿Hay alguna realidad bajo esta polvorienta metáfora? No interroguemos ahora lo que ahora no podemos contestar» ${ }^{12}$.

Por lo pronto aquí comienza a madurar la conciencia individual y personal que dará lugar a la modernidad; según una secuencia que se puede reconstruir desde san Agustín hasta Descartes: «La modernidad nace de la cristiandad; ique no se peleen las Edades, que todas sean hermanas y bien avenidas! » ${ }^{13}$.

Los dioses de la religión griega no son personalistas sino mundanos, mezclados con el trueno, el rayo y la realidad cósmica. El Dios cristiano es trascendente al mundo: «Por esta razón es para el cristiano misterio sumo la encarnación. Que un Dios rigorosamente inçonmensurable con el mundo se inscriba en él un momento - «y habite entre nosotros»- es la máxima paradoja» ${ }^{14}$. Los dioses griegos son de este mundo, andan siempre en correrías humanas. «Pero el Dios cristiano es trascendente, es deus exsuperantissimus. El cristianismo propone al hombre que entre en trato con ser tal» ${ }^{15}$.

10. VII 145-146; HG (1949-1950).

11. VII 386; QF (1929); OTTO, R., West-Oestliche Mystik, Kloz-Gotha 1926, 54; BO.

12. VII 386; QF (1929).

13. Vil 387.

14. Ibid., 385.

15. Ibid. 
Nada de lo que llamamos divino es Dios, incluso las cosas del mundo pueden ser un estorbo para llegar a ese Dios si se las confunde apresuradamente con él. En cierto modo, el cristianismo niega, metódicamente, el mundo para encontrar la divinidad como el filósofo niega, con su duda, la realidad para descubrirla. Es por la soledad como se llega a la compañía de Dios, al dejar de lado todo lo demás: «Niega la realidad del mundo, de los demás seres, del Estado, de la sociedad, de su propio cuerpo. Y cuando ha suprimido todo esto es cuando empieza a sentirse verdaderamente vivir y ser. ¿Por qué? Precisamente porque el alma se ha quedado sola, sola con Dios. El cristianismo es el descubridor de la soledad como sustancia del alma. Digo formalmente como sustancia del alma» ${ }^{16}$. No hace falta recordar ahora que Nietzsche admiraba a los hombres según su capacidad de soledad. El hombre se ha liberado cuando está solo, él mismo, y se dice su verdad una vez la ha descubierto. Es la soledad donde todas las voces hablan. Es el silencio donde todo se escucha, donde el hombre se conoce a sí mismo y reconoce a los demás. Es la soledad sonora donde la realidad se nos desvela y nos habla el misterio: «Debe hacernos meditar el hecho de que Dios sea tan silencioso. ¿Qué bien guarda su secreto! Tal vez es tan dramáticamente mudo porque sabe demasiado sobre nuestro interior y una sola palabra reveladora de lo que piensa de nosotros nos aniquilaría. Certísimo es, por otra parte, que no hay otra manera de acerarse a él sino como al amigo - mediante una 'explicación'. Esta consiste en decirse cada cual a sí mismo algo de lo que Dios le diría, pero correcto, calla; confesándonos la verdad sobre nosotros mismos. Símbolo de esto es la confesión, y no sorprende que las 'Confesiones' de san Agustín no sean otra cosa que la guía de su itinerario hasta Dios» ${ }^{17}$.

Ortega considera que el silencio de Dios es como lo que se callan los amigos que poco a poco dejan de serlo. Y que sólo cuando el hombre es capaz de dar una explicación, como se da a un amigo a quien se ha dejado de ver, puede volver el hombre a encontrarse con Dios nuevamente. Mientras tanto, los humanos tienen tanto que hacer y tantos entretenimientos que no les queda tiempo para dirigirse al corazón del misterio.

El hombre está, de momento, perdido entre las cosas, y el clamor de las profundidades es un clamor en el desierto. También lo es el reclamo del pensador y el de todo profeta mayor o menor: «Bien claro lo hace constar el más grande de los profetas, Isaías, cuando se llama a sí mismo 'voz del que clama en el desierto'. Porque la misión del intelectual es ser el hombre desde su desierto, es decir, desde su radical soledad -y el hombre solo es en su verdad,

16. Ibid.

17. II 632; E VII (1930): «El silencio gran brahmán». 
solo es en sí mismo cuando es en su soledad - clama e invita a los demás para que ingrese cada cual en su propia soledad. El versículo completo de Isaías lo dice de la manera más expresa: Vox clamantis in deserto: Parate viam Domi$n i$, rectas facite in solitudine semitas Dei nostri» (Isaías, XL, ver. 3)... «Cuando el hombre queda solo, de verdad solo, ipso facto aparece Dios. De modo que es quedarse solo con Dios» ${ }^{18}$.

Entonces sobran las palabras, las definiciones extremas y los argumentos, porque ninguna palabra puede definir el gran misterio inefable que llamamos, por decirlo de alguna manera, Dios. Así: «Definir es excluir y negar. Cuanta más realidad posea lo que definimos, más exclusiones y negaciones tendremos que ejecutar. Por esto, la más profunda definición de Dios, suprema realidad, es la que daba el Yaynavalkia: 'Na iti, na iti'. 'Nada de eso, nada de eso'. Observa Nietzsche sutilmente que influye en nosotros más lo que no nos pasa que lo que nos pasa, y según el rito egipcíaco de los muertos, cuando el doble abandona el cadáver y tiene que hacer la gran definición de sí mismo ante los jueces de ultratumba, se confiesa al revés, es decir, enumera los pecados que no ha cometido» ${ }^{19}$.

Dios es lo que nos duele porque nos falta como duele el brazo cortado al que sólo le queda el muñón. El hombre parece vivir ante un enorme enigma, el misterio del Universo, ese algo más en el cual «vivimos, nos movemos y existimos». El hombre es un descifrador de enigmas y de ahí su alegría deportiva al mirar frente a frente lo enigmático: «PPorque todo parecería indicar que alguien ha querido que vivamos náufragos dentro de su inmenso enigma!» ${ }^{20}$.

\subsection{DiOS ESCONDIDO: AGNOSTICISMO Y ATEÍSMO}

El problema religioso está siempre presente, de un modo u otro, pendiente sobre la humanidad como una nube que no es posible evitar. A veces la tempestad es puro viento, otras un nubarrón y algunas veces una lluvia fecunda para la vida y la cultura.

En algunas épocas puede haber como un eclipse. El resto mínimo es siempre el sentido del respeto y la sensibilidad exquisita ante el mundo, los seres, humanos o no, y las cosas. En efecto no es lo mismo ateísmo que irreligiosidad. El ateo suele tener sus causas, también sus buenas razones. La irreligiosidad es frívola de por sí, trivial. No deja que las cosas tengan todo el valor y la

18. IX 226-227; IHU (1948-1949).

19. III 207; Apéndices: «El ocaso de las revoluciones» (1923).

20. VII 177; HG (1949-1950). La búsqueda del ser y de lo divino es «como un amar sin amado y como un dolor que sentimos en miembros que no tenemos»: VII 330-342; QF (1929). Habrá ocasión de volver sobre ello. 
verdad profunda que les pertenecen. Ortega lo ha expresado una vez más excelentemente: «Algunos espíritus groseros podrán confundir el ateísmo y la irreligiosidad: sin embargo, han sido y seguirán siendo cosas distintas. Todo hombre que piense: 'la vida es cosa seria', es un hombre íntimamente religiosos. La verdadera irreligiosidad es la falta de respeto hacia lo que hay encima de nosotros y a nuestro lado, y más abajo. La frivolidad es la impiedad, la 'asebeia' maldita, asesina de razas, de ciudades, de individuos; ella debió ser la más grave tentación de san Antonio, y yo espero que vendrá un tiempo más sutil y profundo que el nuestro en que, perdonándole al Diablo todas sus jugarretas en lo concupiscible, se le execre tan sólo porque es un ser frívolo» ${ }^{21}$.

A veces hay una reacción de furia y pánico ante el ateo. Se le hace enemigo del pueblo porque pone en duda los dioses de la ciudad, la fe colectiva y sus intereses mundanales. Entonces se implican sentimientos proversos y adversos. Pero los problemas no se resuelven solamente con posturas de buen o mal humor. Hay que ver las dificultades, su origen y soluciones. El pensador, como el sacerdote de las tribus zuñi, no se debe enfadar. Insultar, no mejora las cosas. Hay que afrontar el problema: «Los filósofos no se pueden enfadar, porque entonces el orden del Universo se trastornaría y todo andaría manga por hombro" ${ }^{22}$.

Tampoco basta pronunciar la palabra evidencia y decir: jes evidente!, expresión mágica en Occidente, desde Parménides, ya que lo que es es y lo que no es no es. Pero da la casualidad de que lo divino es arcano por naturaleza, poco inteligible que a unos atrae y a otros horripila: «Y los dioses, poderes misteriosos, omnímodos y tremendos inspiran, como es sabido, terror y amor. Porque los dioses tienen siempre dos haces: son favorables y son coléricos, son adversos y son proversos, son atractivos y son terroríficos. Lo santo -como nos hizo ver tan claramente Rudolf Otto- es, a la vez, mysterium fascinans y mysterium tremendum» ${ }^{23}$.

Cierto que para muchos lo divino no es problema, desde su infancia ha sido para ellos una verdad indiscutible y per se nota. Pero sin embargo, llega un día en que lo evidente también se discute. Algunos sospecharán crueldad o violencia en lo sagrado, otros verán en la creencia una deslealtad al mundo. Quizá muchos hombres activos pasen, por ello, de religión y cristianismo. Algunos pueden acusar que el mal humor cristiano crea víctimas; como decía Nietzsche: Destruye el mundo, la historia o la razón. Otros lo verán, el proble-

21. I 436; POC (1916): «Sobre 'El Santo'» (1908).

22. VIII 203-204; IL (1947).

23. Ibid., 212; IL (1947). En nota 2 dice: «Refiriéndose a Dios dice san Agustín: 'Et inhorresco, et inardesco. Inhorresco, in quantum dissimilis ei sum. Inardesco in quantum similis ei sum'»: Confessiones, II, 9, 1. Otto lo cita en apoyo de su doctrina». 
ma, más simplificado porque el cristianismo corriente es la eutanasia del cristianismo ${ }^{24}$, o dirán que la ciencia y la salvación no pueden venir de un Dios que es la vanidad, el deseo de poder, el miedo y la impaciencia de los hombres.

A veces, también, se ha sospechado que las divinidades «quieren mantener la especie humana en domesticidad» ${ }^{25}$. Castigan al indócil. Los caprichos de los dioses y sus patrañas ponen cínicamente al descubierto su naturaleza contradictoriamente teológica. Otros parecen pura magia en acción. A veces hostiles, a veces neutros, con frecuencia solitarios. Bastante azarosos, sin posible contento. No dan lugar a la plegaria ni a la esperanza, divinidades ciegas, sin figura ni rostro. Patrocinadores de lo inhumano y negligentes con el mundo. Despojan del todo al hombre. Solamente le dejan con la última energía de la caja de Pandora: «Esta fuerza es 'la esperanza', maravillosa emanación humana perfectamente infundada y sin razón, gloriosamente arbitraria, que segregamos continuamente frente al albur que es todo mañana» ${ }^{26}$.

Para acabarlo de arreglar, los grandes ideales a que dieron origen las religiones parecen desembocar continuamente en frustraciones: «La historia nos presenta en su amplísimo panorama la peregrinación de nuestra especie por el vasto repertorio de los ideales y certifica que fueron, a la vez, encantadores e insuficientes. ¿No es cierto que la historia toda, mirada bajo cierto sesgo, adopta una actitud donjuanesca?» ${ }^{27}$.

La misma religión y el amor que propala se enredan y anulan amorosa y religiosamente: «De esta manera hemos hecho de esas dos cosas radiantes y benéficas dos cosas turbias, exageradas, fantasmagóricas, cuando no atroces instrumentos de martirio" ${ }^{28}$.

Ante esta situación, algunos creyeron que debían seguir el camino ateo si habían de hacer algún bien en la vida. Cambiaron el cristianismo religioso por la solidaridad obrera. Es el origen de un discurso 'ruidosamente ateo' que no es sólo retórica aunque también sea retórica. Cuenta uno de estos hombres cómo de niño se encontró en los barrios proletarios bilbaínos: "'Y allí, en ese ambiente, se fue formando mi espíritu y, repasando los tristísimos recuerdos de una infancia desvalida, me hice, no sé si de pronto o lentamente, como se constituyeron las formaciones espirituales más recias, me hice el propósito, me tracé el designio de servir de por vida a todos los desvalidos, a todos los

24. Nietzsche, F., Aurore. Réflexions sur les préjugés moraux, traduit par H. Albert, Mercure de France, Paris 1930, 101-102; BO.

25. I 554; POC (1916): «La Gioconda» (1911).

26. IX 656; PPHA (1951-1954).

27. VI 137; TAO (1942): «Introducción a Don Juan», II, El Sol (6.1921).

28. II 26; E I (1916): «Leyendo el Adolfo, libro de Amor». 
humildes, a todos los miserables, entre los cuales me encontraba y con los cuales tuve siempre fuertes lazos espirituales» ${ }^{29}$.

A Ortega esto le parece una forma de religión y concretamente de cristianismo: «Señores, quiera o no el ministro socialista, eso es esencial cristianismo -es cristianismo en hueco. Si no hubiera habido cristianismo, no se le habría ocurrido a este hombre dedicar su vida a algo. He ahí lo fundamental de la experiencia cristiana del hombre: todo lo demás es secundario, casi anecdótico al lado de eso» ${ }^{30}$.

Para Ortega lo fundamental del cristianismo es descubrir que hay que tomar la propia vida en vilo y darla a los demás. El hombre antiguo ignoraba esto y se dedicaba a aguantar la fatalidad estoicamente: «Pero desde el cristianismo el hombre, por ateo que sea, sabe, ve, no ya que la yida humana debe ser entrega de sí misma, vida como misión premeditada y destino interior - todo lo contrario que aguante de un externo destino- siho que lo es, queramos o no. Díganme ustedes qué otra cosa significa la frase tan repetida en el Nuevo Testamento y como casi todo el Nuevo Testamento tan paradójica: 'el que pierde su vida la gana'. Es decir, da tu vida, enajénala, entrégala, entonces es verdaderamente tuya, la has asegurado, ganado, salvado» ${ }^{31}$.

Según Ortega, la religión es respeto y responsabilidad, hacerse cargo de la propia vida y responder con ella a las llamadas de los otros y del mundo. Pero desde el quattrocento comienza a sustituirse el cristianismo por la religión natural, puesto que, según el cardenal Cusano, Dios es un Dios escondido - una de sus obras se llama De deo abscondito- y no todos pueden llegar a conocer con toda perfección la religión. Por tanto se llama a la tolerancia, incluso a los españoles, pues un español, Torralba, es el que la recomienda en el Colloquium heptaplomeres de Bodino ${ }^{32}$.

El deísmo del siglo XVII trata de llenar el hueco que dejó el cristianismo. El siglo XIX intentó lo mismo con la teologización de la cultura. Después de la Edad Media la piedad se vuelve hacia el mundo: «Y vimos cómo aun la devotio moderna era ya una mundanización de la fe, era vivir desde Dios, pero cara al mundo... Servimos a Dios precisamente cuando servimos a este mundo, en el oficio o vocación en que Dios nos ha puesto" ${ }^{33}$. Eso mismo hicieron Lutero y san Ignacio de Loyola. Los que en esos siglos prescinden de la religión se convierten en malhechores. Especialmente esto ocurre después de la Edad Media. Es una etapa, según Ortega, exacerbada de crímenes. La Roma ininte-

\footnotetext{
29. V 154; EG (1933).

30. Ibid.

31. Ibid., 154-155.

32. Ibid., 155 .

33. Ibid., 156.
} 
ligible de los Borgia. El mundo se hace independiente de Dios. Así tenía que ser. El ockamismo consumó la obra desde un punto de vista teórico y dejó al descubierto el mundo naturalista que Aristóteles había ideado. «Ahora se ve lo poco que la interpretación cristiana fue aprovechada para la interpretación de las cosas» ${ }^{34}$.

En vez de ir a una religión en el mundo se fue a una división de lo mundano en un plano astral inmutable y en otro finito sin valor alguno. Así en la vida ya no tiene trascendencia nada. Se es ateo de todo. $Y$ esto proporciona una fabulosa ilusión de libertad aunque en el fondo se termine por envidiar al sinvergüenza. Aquí aparece ya el español, numantino siempre a la desesperada, incapaz de salir del propio pozo ${ }^{35}$. Y comienza a fraguarse el espíritu violento y nihilista propio de la fuerza bruta del ser griego: «El nihilista, no estimándose a sí mismo, sintiéndose incapaz, busca compensación aniquilando los valores del mundo. Así se pone a la par. A su lado Luzbel es un santo porque su acto supone: primero, entusiasta reconocimiento de que hay una cosa óptima en el mundo: Dios; segundo, deseo de ser como esa optimidad; tercero, convicción subsecuente de que hay otra cosa óptima; él, que es como Dios. Al nihilista tiene Luzbel que parecerle ingenuo, porque cree que hay en el mundo algo que vale la pena y se comporta ante ello con sentimientos afirmativos. Luzbel es el snob de Dios» ${ }^{36}$.

Frente al nihilismo y a la niebla, la religión debe aportar clarìdad. Dolores, tinieblas y espontaneidad ya tiene bastante la vida de carne y hueso. Se necesita la claridad, la cultura como plenitud de vida: «Para vida, para espontaneidad, para dolores y tinieblas me bastan con los míos, con los que ruedan por mis venas; me basto yo mismo con mi carne y mis huesos y la gota de fuego sin llama de mi conciencia puesta sobre mi carne y sobre mis huesos. Ahora necesito claridad, necesito sobre mi vida un amanecer» ${ }^{37}$.

Ésta fue la Aurora que Ortega estuvo siempre buscando. La que Nietzsche creía preparar y la que Jacob Boehme decía que iba a estallar por fin en el corazón del hombre, la luz de la vida, que anuncia un nuevo amanecer, «die Morgenröte des neuen Tages» ${ }^{38}$.

No se puede reducir todo a utilidades e intereses, a obscuridades y realidad turbia. Eso sólo lo consiguen los triviales absolutos. Por este camino hasta las personas pueden convertirse en cosas. Pero ésa es la dirección de lo in-

34. I 158.

35. V 245: «La estrangulación del 'Don Juan'», El Sol (17.11.1935).

36. II 719; E VIII (1934): «Revés de almanaque» (1930).

37. I 359; MQ (1914): «Integración».

38. Bozhme, J., Morgenroete, München-Leipzing 1912, XLV: «Gott ist die Tat». 
humano, no el método digno del hombre y el respeto que le pertenece por ser un fin en sí y no una cosa: «Kant reduce la moral a su conocida fórmula: obra de tal manera que no emplees solo como medios a los otros hombre, que sean como fines de tus propios actos. Hacer, como Kant, de estas palabras la expresión de una norma y el esquema de todo deber equivale a declarar que de hecho cada uno de nosotros usa de los demás congéneres, los trata como cosas. El imperativo de Kant, en sus varios dictados, aspira a que los demás hombres sean para nosotros personas, no utilidades, cosas. Y esta dignidad de la persona le sobreviene a algo cuando cumplimos la máxima inmortal del Evangelio: trata al prójimo como a ti mismo. Hacer de algo un yo mismo es el único medio para que deje de ser cosa» ${ }^{39}$. Pero con frecuencia, olvidamos que 'tú' y 'él' también son 'yo' y los utilizamos como cosas.

Según todo lo dicho la irreligiosidad nunca tiene sentido, para Ortega, porque es la falta de sensibilidad, de respeto, la inhumanidad, lo zafio y lo trivial. La irreligiosidad es la incultura, la falta de cultivo y nivel humano normal. En cambio el ateísmo tiene sus justificaciones, como pueden ser, el temor que causa lo religioso, el excesivo respeto a la divinidad; también, la falsificación de la religión por medio de fábulas, su utilización contra las peronas y la cultura, o su explotación por los mismos que dicen ser sus enviados en beneficio propio y de sus intereses mundanales. Ante este gran engaño algunos optaron por hacer una trasposición civil del evangelio cristiano con el fin de sustraerlo a la utilización nefasta de sus detentores oficiales.

Ante el ateo, por tanto, el filósofo no se puede enfadar sino buscar el origen de las situaciones y recordar que el Dios verdadero es un Dios escondido como dice la Biblia. Otra cosa sería si el hombre pretendiera jugar al escondite con él o sustraerlo a la experiencia humana. Esto ya no lo vería leal Ortega. Y, como él nos dice, ha ocurrido. Es la postura del agnosticismo.

El siglo pasado, quiso cortar el paso violentamente a las cuestiones últimas y decisivas: «Esta violencia, este volverse de espaldas a los últimos problemas se llamó 'agnosticismo'» ${ }^{40}$. El agnosticismo es una postura muy curiosa, negativa. «Equivale a llamarse No-Pedro o No-Juan. Y, en efecto: agnóstico significa 'el que no quiere saber ciertas cosas'. Se trata, por lo visto, de un alma que antepone a todo la cautela y la prudencia: al emprender, el evitar; al acertar, el no errar. Y el caso es que las cosas cuya ignorancia complace al agnóstico no son cualesquiera, sino precisamente las cosas últimas y primeras; es decir, las decisivas» ${ }^{41}$.

39. VI 250; Prólogos; «Ensayo de estética a manera de prólogo» (1914).

40. II 608; E VII (1930): «El origen deportivo del Estado» (1924). Cfr. también Ibid., 311312; QF (1929).

41. II 494; E VI (1927): «Dios a la vista» (1926). Subrayado nuestro. 
Para Ortega esta experiencia es hoy difícil de revivir. Pues, según él, el agnóstico no dice que la realidad inmediata es la única que existe. Por el contrario, admite que 'la realidad inmediata no es la realidad completa', que más allá de lo visible hay algo más. Pero el agnóstico le da la espalda y se desentiende de él. «La consecuencia de ello es que el paisaje agnóstico no tiene últimos términos. Todo en él es primer plano, con lo cual falta a la ley elemental de la perspectiva. Es un paisaje miope y un panorama mutilado» ${ }^{42}$.

Se renuncia, con laudables pretextos, a buscar las cosas fundamentales, enredados únicamente en lo inmediato. Se vuelve a decir como Parménides: esto es lo que hay, lo que hay en este mundo. "Porque 'este mundo' es lo que queda del Universo cuando le hemos extirpado todo lo fundamental; por tanto, un mundo sin fundamento, sin asiento, sin cimiento, islote que flota a la deriva sobre un misterioso elemento" ${ }^{43}$.

Ortega cree que el agnóstico surge por oposición al 'gnóstico' que siente asco de este mundo y vive en el ultramundo. No se interesa por éste. Es lo contrario del positivista. Encuentra la salvación en huir de lo presente y atender sólo al futuro. Sin embargo, esta reacción excesiva no justifica el agnosticismo. A todo hombre, incluido el físico que vive fundamentalmente alojado en este mundo «se le va el alma hacia esa primera y enigmática causa. Es natural que sea asì» ${ }^{44}$. Según Ortega no se puede vivir sordo a las postreras y dramáticas preguntas: «¿De dónde viene el mundo, a dónde va? ¿Cuál es la potencia definitiva del cosmos? ¿Cuál el sentido esencial de la vida? No podemos alentar confinados en una zona de temas intermedios, secundarios. Necesitamos una perspectiva íntegra, con primero y último plano, no un paisaje mutilado, no un horizonte al que se ha amputado la palpitación incitadora de las postreras lontananzas. Sin puntos cardinales, nuestros pasos carecerían de orientación. Y no es pretexto bastante para esa insensibilidad hacia las últimas cuestiones declarar que no se ha hallado manera de resolverlas. ¡Razón de más para sentir en la raíz de nuestro ser su presión y herida! ¿A quién le ha quitado nunca el hambre saber que no podrá comer? Aun insolubles, seguirán esas interrogaciones alzándose patéticas en la comba faz nocturna y haciéndonos sus guiños de estrella - las estrellas, según Heine, son inquietos pensamientos de oro que tiene la noche. El Norte y el Sur nos orientan, sin necesidad de ser ciudades asequibles, para las cuales quepa tomar un billete de ferrocarril» ${ }^{45}$.

42. Ibid., 495 .

43. Ibid.

44. VII 311; QF (1929).

.45. II 608; E VII (1930): «El origen deportivo del Estado» (1924). 
La ciencia solamente responde cuestiones penúltimas y las preguntas últimas 'queramos o no' se levantan en nosotros.

Esto no quiere decir que la tarea sea fácil ya que lo divino, para que no sea lo humano, debe de ser lo absolutamente otro, nunca se capta del todo como tampoco se consigue del todo el objeto aunque la conciencia parece, en principio, absoluta e ilimitada. De hecho, todo conocimiento es tanteo, averiguación, y en cierta manera apocalipsis. Precisamente porque: «El ser, la cosa misma, es por esencia lo oculto, lo encubierto, es el señor del antifaz» ${ }^{46}$.

El pensador debe ser en este sentido escrupuloso, cuidadoso en sus averiguaciones. Parece que el hombre no se descubre rápidamente religado a lo divino. Lo religioso no estaría para Ortega, en este momento directamente en relación con religio y religar sino a través del adjetivo religiosus: «Como tantas veces, es el adjetivo quien nos conserva la significación original del sustantivo, y religiosus quería decir 'escrupuloso'; por tanto, el que no se comporta a la ligera, sino cuidadosamente. Lo contrario de religión es negligencia, descuido, desentenderse, abandonarse. Frente a relego está nec-lego; religente (religiosus), Aulo Gelio, IV, 9, se opone a negligente» ${ }^{47}$. Lo nuevo es ser elegante.

No basta sentirse seguro, terco y más o menos simplista. Es necesario también aprender a dudar. Renan rogaba a Dios que le mantuviera en la duda porque es sana y bella. El dogmático, de lo que sea, se cierra muchos horizontes. Con frecuencia: «El escéptico es el hombre de vida más nutrida, más rica, y completa. Una torpe idea nos lleva a presumir que el escéptico no cree en nada. Todo lo contrario. El escéptico se diferencia del dogmático en que este cree en una sola cosa y aquel en muchas, en casi todas» ${ }^{48}$.

La cultura auténtica, incluida la religiosa, debe ser siempre clarificadora e iluminadora. Pero lo religioso es a su vez problema. «Ésta es la dificultad con que tropieza la religión y que la ha mantenido siempre en polémica con otras formas de la humana cultura, sobre todo con la razón. El espíritu religioso refiere el misterio que es la vida a misterios todavía más intensos y peraltados. Al fin y al cabo, la vida se nos presenta como un problema acaso soluble o, cuando menos, no a limine insoluble» ${ }^{49}$. En la religión no siempre se puede decir otro tanto. No obstante estamos ante un retoñar de la filosofía y de los problemas superiores y decisivos: «Asistimos a un renacimiento de lo que Schopenhauer llamaba la 'necesidad metafísica' del hombre» ${ }^{50}$.

46. I 351; «Apuntes sobre el pensamiento, Buenos Aires 1941.

47. VI 64; «Del Imperio romano», La Nación (Buenos Aires 1940).

48. VI 140; TAO (1942): «Paisaje con una corza al fondo», El Sol (1927).

49. I 358; MQ (1914).

50. I 244: «Sobre el concepto de sensación», Revista de Libros (1913). 
Las cosas no son nunca de un solo color. Cervantes tiene que sospechar de la nobleza del siglo XVI y delata su heroica hipocresía. En el mismo siglo se recoge la cosecha que daba el Renacimiento y a la vez acepta la contrarreforma. Galileo crea la nueva física pero se desdice ante las presiones dogmáticas. «Es el siglo en que Descartes, apenas descubre el principio de su método, que va a hacer de la teología ancilla philosophiae, corre a Loreto para agradecer a Nuestra Señora la ventura de tal descubrimiento. Este siglo de católicos triunfos no es tan mala sazón que no puedan llegar, por primera vez, a levantarse en él los grandes sistemas racionalistas, formidables barbacanas erectas contra la fe. Vaya este recuerdo para los que, con envidiable simplismo, cargan sobre la Inquisición toda la culpa de que España no haya sido más meditabunda» ${ }^{51}$.

Esto no quiere decir que Ortega vaya a aceptar determinados abusos de la espiritualidad religiosa. Así recrimina a Max Scheler por mezclar el reino de Dios con el problema de la guerra. A Max Scheler, precisamente, que es para Ortega uno de los hombres más representativos de la generación alemana y ejemplar típico del profesorado joven. Para Ortega ese modo de hablar sin precauciones, sin consistencia lógica, es un cinismo: «Pues como hay un cinismo de la carne lo hay también del espíritu» ${ }^{52}$.

En el escrito sobre el belicismo Scheler hacía una metafísica del Estado y, en concreto, de la guerra como 'juicio de Dios'. Aprovechaba el momento para teologizar sobre la inmortalidad. $Y$ teologizaba incluso la guerra y la entrada en combate donde cada uno se refiere a Dios como suyo. Ortega teme que el 'nuestro' del Padre nuestro se termine por confundir con «nuestro viejo Dios prusiano" ${ }^{33}$.

Y sentencia Ortega: «La verdad es que no sabe uno cuál calle tomar. Yo no puedo leer una página de dogmatismo espiritualista y religioso como la transcrita sin sentir repugnancia. Y, por otra parte, experimento pareja repulsión cuando me acuerdo que hay en el mundo Librepensadores y gentes según las cuales de Dios y de la fuerza vital no se puede hablar» ${ }^{54}$.

Para Ortega todo esto es mucho menos dogmático que lo que el sentido común propone. La perfección intemporal no es tampoco algo seguro sino más bien lo contrario. Incluso la vida necesita de la muerte: El rey ha muerto, ¡Viva el rey! todo es una dialéctica entre lo temporal y lo eterno: « ¡Oh, sí, la mayor sabiduría es secundar esta misteriosa universal voluntad de vida! Aprendamos a preferir lo corruptible a lo inmutable, la trémula mudanza de

51. I 367; MQ (1914).

52. II 221; E II (1917): «El genio de la guerra y la guerra alemana» (1916).

53. II 221 nota 2 .

54. Ibid., 221. 
la existencia a la esquemática y lívida eternidad. Seamos de nuestro día: mozos al tiempo debido, luego espectros o sombras en fuga. Lo decisivo es que llenemos hasta los bordes la hora caminante, que seamos en el ánfora grácil buen vino que rebosa» 55 .

Ortega quiere huir del tratamiento trivial que da a la vida, la masa, y desea que haya sensibilidad para los grandes problemas del arte, de la ciencia, de la política superior o de la religión. Con un espíritu siempre abierto y profundo. Le gustaría haber conocido a aquel hombre del siglo XV que tuvo como divisa: «Rien ne m'est sûr que la chose incertaine» ${ }^{56}$.

El espíritu fanático le horrorizaba a Ortega. Así lo demostró muchas veces en su vida. vgr. en los acontecimientos españoles o en la neutralidad Argentina cuando se hacía insostenible. Es un talante, el de nuestro autor, que sólo se entusiasma con lo verdadero y auténtico: «Quien sabe que la íntima disputa es el ser auténtico del hombre no puede sentir gran empeño en convencer a nadie de nada. Sólo el fanático, el que no es para sí hombre, el petrefacto humano, es persuasivo, luchador, proselitista. Es decir, los que no han pensado nada por sí son los que se afanan en convencer a los demás de muchas cosas» ${ }^{57}$.

El conocimiento es el respeto, la fidelidad a lo real. La libertad dada a las cosas para que sean lo que son de suyo y por sí mismas, sin esclavitudes. Es preciso aprender a pensar como un incesante alerta a fin de ser fieles a lo real. El naturalismo ha terminado porque es el reflejo del pensamiento. Éste es siempre lógico, la realidad no tanto: «Ya el objeto matemático presenta simas de ilogicismo tan tremendas como el 'laberinto de las dificultades de lo continuo' y todos los problemas que inspiraron a Brouwer el intento de derrocar el principium tertii exclusi. La física nos sorprende hoy dramáticamente con los estados de in-identificación de los elementos atómicos» ${ }^{58}$.

Es necesario seguir la trayectoria de Kant para no continuar prisioneros del eleatismo - larvatus prodeo- esclavos del destino y la estabilidad estática, siempre lo mismo, sin dinamismo. Algo invariable, permanente. «Ahora bien: poner como condición a lo real, para que sea admitido como tal, que consista en algo idéntico, fue la gigantesca arbitrariedad de Parménides y, en general, del griego ortodoxo" ${ }^{59}$. No se mantiene ya en pie el Deus sive Natu$r a$. El concepto de Espíritu también es, con frecuencia, 'un naturalismo larvado', con una consistencia estática. Lo humano se rebela contra este modo de

55. Ibid., 231-232, E III (1921): «Leyendo 'Le petit Pierre' de Anatole France» (1919).

56. II 735; E VIII (1934): «Revés de almanaque» (1930).

57. II 737; E VIII (1934): «Revés de almanaque» (1930).

58. VI 30; HS (1935).

59. VI 29; HS (1935). 
ser concebido y hace consistir al espíritu en actividad: «¡Intento vano! Porque esa actividad, como toda actividad, es siempren (sic) una y la misma, fija, prescrita, ontológicamente inmóvil. En Hegel, el movimiento del espíritu es pura ficción, porque es un movimiento interno al espíritu, cuya consistencia es en su verdad fija, estática y preestablecida. Ahora bien: toda entidad cuyo ser consiste en ser idéntico posee evidentemente ya y desde luego todo lo que necesita para ser. Por esta razón, el ser idéntico es el ser substante o substancia, el ser que se basta a sí mismo, el ser suficiente. Esto es la cosa. El espíritu no es sino una cosa» ${ }^{60}$.

Fichte, según Ortega, palpa el ser de la vida pero es eleático, por eso parece un ciego perdido en las sierras de la metafísica. Es el entendimiento identificante que naturaliza y cosifica. Hay que volver al respeto a las cosas y a la vida y dejar su actual conocimiento-sometimiento, sin lo cual no es posible la experiencia del ser y menos de lo divino.

\subsection{El PROBLEMA DE DIOS: DIOS AL FONDO.}

\subsubsection{Dios brilla por su ausencia}

El Dios cristiano no se deja ver. Todas las pruebas y todos sus nombres no son acerca del Dios verdadero. Éste es otra cosa. Lo decía san Agustín «aliud, aliud, valde $a b$ istis omnibus» ${ }^{61}$. Lo sabía también nuestro clásico por eso citaba al profeta que dice: "Verdaderamente tú eres un Dios escondido». La fe y el amor eran para él esos mozos de ciego por donde se llega al misterio. Y la cosa termina así: "Nunca te quieras satisfacer en lo que entendieres de Dios, sino en lo que no entendieres» ${ }^{62}$.

Por medio de su pensamiento el hombre va alcanzando algunos apuntes de lo desconocido con un esfuerzo milenario. De muchos humanos: «Períodos y razas -o, en una palabra, las culturas - son los órganos gigantes que logran percibir algún breve trozo de ese trasmundo absoluto. Mal puede existir una cultura que sea la verdadera cuando todas ellas poseen sólo un significado instrumental y son sensorios amplísimos exigidos por la visión de lo absoluto» ${ }^{63}$.

Comte y Hegel intentaron congelar el pasado, la historia, lo absoluto, pe-

60. VI 30; HS (1935).

61. Citado por Heiler, F., Der Katholicismus, Reinhardt, München 1923, 372. BO.

62. SAN JuAN de la CRuz, El Cántico espiritual, La Lectura, Madrid 1924. 31. BO. BARUzI, J., Saint Jean de la Croix et el problème de l'éxperience Mystique, F, Alcan, Paris 1931, 2a. BO. Hay una dedicatoria a mano de Baruzi a Ortega que dice: «En hommage d'admiration et de gratitude très amicale». El texto tiene citas de Przywara, Blondel, Maritain, R. Otto y otros (XVII y siguientes).

63. III 313, Las Atlántidas (1924). 
ro, según Ortega, eso no pasa de ser un espejismo. La realidad y su conocimiento profundo es utópico - como todo lo que el hombre hace- y es inútil exigir su realización plena; como es falso obstinarse en llegar «al absoluto Norte que, claro está, no existe» ${ }^{64}$. En el camino del desierto hay que beber del pozo y dejar el sitio a otro.

Las culturas tienden a ver lo divino como ellas viven. Los dioses del lejano oriente son lentos como su medio ambiente es pacífico y reposado. Platón nos puso en guardia contra estas trasferencias al llamarnos a mantener un diálogo constante con las cosas. Kant impide que el yo y las cosas se vayan por las nubes. No es casualidad que los griegos, para evitar una excesiva proliferación, tuvieran un dios desconocido, que S. Pablo intenta utilizar para introducir un Dios total ${ }^{65}$. También Sto. Tomás nos dice que al subir en la escala de los seres se llega a Dios que 've o intuye en una sola idea'. Kant, por su parte, confirma: «El pensamiento categorial se nos muestra así, según Kant, como el más irrefutable testimonio de nuestra finitud y limitación. 'Para un entendimiento divino - escribe en la Crítica de la razón pura, I, p. 261 - no tendrían significación alguna las categorías'» ${ }^{66}$.

Los hombres sólo columbramos lo eterno; la humanidad entre el orangután y Dios es como un gesto de divinidad. Se busca un conocimiento totalmente objetivo pero se da con las cosas, incluso con la gran cosa que es Dios, siempre en fuga: «La humanidad es el camino que lleva hacia Dios, o lo que es lo mismo, a la absoluta objetividad en que nada hay secreto, sino todo patente, todo cosa. En España solemos decir, cuando algo es muy bueno: esto es una gran cosa. Tal vez en el dicho vulgar vaya incluida una profunda sospecha teológica, según la cual la Gran cosa por excelencia sería Dios. Pero la absoluta objetividad significa una meta infinitamente remota, a la que sólo podemos aproximarnos, sin toparla nunca» ${ }^{67}$.

El conocimiento es una operación paradójica que sólo llega a cumplirse en el hombre en cuanto se hace otro. Un des-hacerse para hacerse otra cosa que no es. Un ansia infinita «de ser parte del ser universal, que empuja contra nosotros sus formidables espumas metafísicas» ${ }^{68}$. Lo oriental y lo occidental se unen en este proceso común que aquel describe como una disolución en el Nirvana y éste, por el maestro Eckhardt, nos avisa del posible y propio fracaso: «Cada ser fracasa en la medida en que no es los demás seres. Consiste,

64. VI 418; Prólogos; "A la Historia de la Filosofía de Emile Bréhier», Buenos Aires (1942).

65. Rubert de Ventos, X., Filosofía y/o política, Península, Barcelona 1984, 86.

66. Ibid., 87 , nota 40 .

67. I 446-447; POC (1916): «Renan» (1909).

68. III 558; EL (1927): «Para un libro no escrito». 
pues en una negación infinita; su ser está tejido de no ser esto, de no ser lo otro, etc.» ${ }^{69}$. No se puede confundir por tanto la visión de lo absoluto con la manipulación del universo, de lo divino o de la vida, como ha sido frecuente entre los occidentales. La realidad es un caballo al galope que no se alcanza fácilmente. No vale intentar detenerla a la desesperada; o agarrarse a lo objetivo, como el fariseo a la ley, en vista de la conciencia oculta de naufragio. En el fondo, toda vida humana es un mar difícil que vive con la esperanza de llegar un día a buen puerto. Como el judaísmo que vive del futuro esperado, el conocimiento humano está ante lo absoluto con esta sensación de espera, en mágica expectativa: «La gente vive fuera de sí, en un mañana que se cree inminente. ¡Ya viene, ya viene! ¿Quién? El otro, el otro que puede más que nosotros porque lo puede todo, que nos completa, que nos salva: el Mesías instaturador del reino. $\mathrm{Y}$ vuelve a sonar con nuevo vigor la súplica urgente que ha sostenido durante milenios a este pueblo futurista marama (sic) za! Señor nuestro ven -expresión por cierto de donde vino en España llamar a los judíos conversos 'marranos', es decir los del marana $z a ! »{ }^{70}$.

Es la misma canción de Tagore, la sensibilidad de la promesa, del Dios hindú que recorre los caminos aldeanos, zagal y hondonero, poeta y profeta, de ímpetu multiforme que huye de la economía política tanto como de la academia y del hotel. Él mismo lo dice: 'He cantado muchos cantos en muchos modos - escribe Tagore-; pero todas sus notas siempre claman: Ya viene, ya viene para siempre'.

-Pero ¿quién viene, diablo - pregunta usted, enemiga de lo impreciso, impaciente y nada asiática.

-Señora, Dios - respondo obediente» ${ }^{71}$.

Dios es siempre ese que se espera y nunca sabemos si llega y cuándo. ¡Esperamos a ver si viene, como Kafka, como S. Beckett, como todo hombre peregrino del absoluto! Es un difícil no saber a qué atenerse, siempre a la búsqueda. Es la herida, el hueco que hace el problema en nosotros y nos da conocimiento. Ortega avisa a un joven filósofo: «Créame: no hay nada más fecundo que la ignorancia consciente de sí misma. Desde Platón hasta la fecha, los más agudos pensadores no han encontrado mejor definición de la ciencia que el título antepuesto por el gran Cusano a uno de sus libros: De docta ignorantia. La ciencia es, ante todo y sobre todo, un docto ignorar. Por la sencilla razón de que las soluciones, el saber que se sabe, son en todos sentidos algo se-

69. III 559; EL (1927): «Para un libro no escrito».

70. V 101; EG (1933).

71. III 23; «Estafeta romántica», El Sol (31.3.1918). 
cundario con respecto a los problemas. Si no se tiene clara noción de los problemas, mal se puede proceder a resolverlos» ${ }^{72}$.

Cuando se confunden los planos y niveles y se trastocan unas cosas con otras, la vida se desorganiza y degenera, se pierde el orden apropiado y se acaba por intentar el imperialismo omnímodo de lo ínfimo o de lo supremo. Se cae en el ridículo y lo grotesco. La frustración de las solemnidades deslumbrantes conduce directamente a la apatía más ordinaria. Wagner se hace un Bismarck del pentagrama: «La poesía destronada, acabó, con Verlaine, por guarecerse en el hospital, mientras Wagner, sobrepasando al flautista Schopenhauer, proponía en Parsifal un sustituto de la religión»" ${ }^{73}$.

Un buen orden humano, no debe, por el contrario, significar el anquilosamiento filisteo que cree en la eternidad de sus instituciones y teorías. Según él, nada puede cambiar. Su sistema preferido le parece inconmovible y fijo por toda la eternidad: «Y asimismo las opiniones sobre Dios y sobre el hombre. $\mathrm{Y}$ asimismo el gusto artístico y el código moral» ${ }^{74}$. No se da cuenta del dicho de Sófocles de que nada hay que no pueda sobrevenir. Así se camina hacia una vida insustancial, puramente exterior, diplomática, carente de sensibilidad verdadera. El ideal de Ortega es bien distinto: «Todos los individuos auténticamente personales que he conocido tenían dos vidas - una de ellas simple coraza de la otra» ${ }^{75}$. El intelectual trata de trasmitir esa enorme sensibilidad oculta. Se expone a sí mismo a los demás. Algunas veces tiene el sentimiento de estar haciendo algo impudoroso, de introducirse descaradamente en el misterio. Le avergüenza el no intelectual, el que no ve ningún secreto en las cosas, en el universo y su arcana existencia, en la enfermedad, el que simplemente cuenta con las cosas y las usa: «Es un egoísta nato» ${ }^{76}$.

En cambio, la realidad se complace en ocultarse como dijo Heráclito. Y su verdad es apocalipsis, revelación y descubrimiento: «El universo es, por lo pronto, un constante carnaval. Máscaras nos rodean. Los árboles no dejan ver el bosque, la fronda no deja ver el árbol y así sucesivamente. El ser, la cosa misma, es por esencia lo oculto, lo encubierto, es el señor del antifaz» ${ }^{77}$.

Al principio había mucha seguridad en las cosas, el griego creía que la realidad era el cosmos: piedras, animales, plantas o realidades psicocorporales. Llega otro momento en que la vida no parece encontrarse verda-

72. II 347; E IV (1925): «Carta a un joven argentino que estudia filosofía» (1924).

73. II 336; E IV (1925): «Apatía artística» (1921).

74. II 30; E I (1916): «Horizontes incendiados» (1916).

75. V 479; IC (1940): «Memorias de mestanza», La Nación (Buenos Aires 10. 1936).

76. V 514; «El intelectual y el otro», La Nación (Buenos Aires 12.1940).

77. V 525; «Apuntes sobre el pensamiento, su teurgia y su demiurgia», en Logos, Revista de la Facultad de Filosofía y Letras. Universidad de Buenos Aires (1941). 
deramente en esos niveles. El cristianismo decide que la realidad verdadera es Dios: «Cuando el griego meditaba sobre esa realidad e intentaba descubrir su estructura esencial, llegaba a conceptos como sustancia, causa, cualidad, movimiento, etc.; en suma, a las categorías del ser cósmico. Pero ahora la realidad significa algo que no es corporal, ni siquiera psíquico - ahora la verdadera realidad consiste en el comportamiento del hombre con Dios-, en algo, pues, tan inmaterial, tan incorporal, que llamarlo espiritual, como se le llamó, es ya materializarlo inadecuadamente» ${ }^{78}$.

Al cristiano no le sirven de nada, o de muy poco, los conceptos de la filosofía griega. San Agustín intenta descubrir nuevos conceptos. «Pero no bastaba un hombre, por genial que fuera: era menester des-pensar todos los viejos conceptos, liberarse de ellos y forjar toda una ideología radicalmente original. La masa enorme y sutilísima de ideología griega, gravitando sobre estas horas germinales del pensamiento cristiano, lo aplastó» ${ }^{79}$. El platonismo sedujo a muchos cristianos, en parte también a Agustín. El platonismo, para Ortega, «no es en ningún sentido cristiano» ${ }^{80}$. A las ideas platónicas puede llegar cualquier hombre, al Dios cristiano ninguno, a no ser que Él mismo se revele: «El atributo más característico del Dios cristiano es éste: Deus ut revelans. La idea de la revelación, como la idea de creación, es una absoluta novedad frente a todo el ideario griego» ${ }^{81}$. En los griegos es el hombre el que busca a Dios; para los cristianos es Dios quien viene «a buscar al hombre y apoderarse de él, inundarlo, penetrarlo, transirlo, es la fe, la fe divina» ${ }^{82}$. No hay otro conocimiento verdadero sino éste. El predominio de lo razonable sin paradoja, de la experiencia y el progresar, construye la vida sobre un fundamento falso, sin fundamento. Así la religiosidad es un equívoco farisaico, es como querer ser Dios. No se da cuenta de que la vida del hombre no tiene otro fundamento que un puro y absoluto milagro de lo alto: «Gott allein will recht haben» ${ }^{83}$. Entonces parece que el cristiano va a salirse del mundo.

Pero en un segundo momento, los creyentes 'se encuentran ya instalados en la experiencia cristiana. El hombre la vive y debe entenderse con ella: «No: el hombre no es simplemente nada, aunque sea muy poco. Hasta para que haya fe tiene que intervenir, quiera o no - puesto que necesita entender la fe- la palabra de Dios. Tal es la situación de san Anselmo. Estamos en el siglo XI. Frente al lema de san Agustín: Credo ut intelligam, el de san Anselmo suena

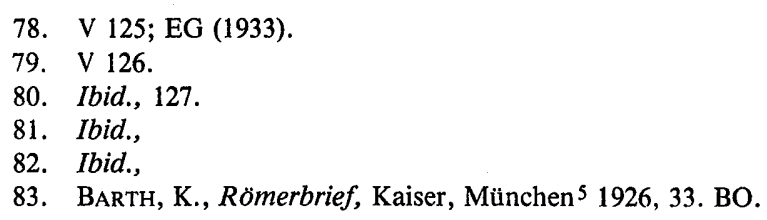


así: Fides quaerens intellectum» ${ }^{84}$. La fe necesita inteligencia. Comienza a incorporarse la razón humana, nace la confianza en la naturaleza humana. Llega así la teología escolástica. Santo Tomás reconoce el máximo espacio a la razón humana, la fe se reduce a sus propios límites: «Yo diría: se reconoce un estatuto al hombre y éste cobra conciencia de su poder y sus derechos, más aún, tiene obligación de afirmar sus cualidades naturales, sobre todo la razón» ${ }^{85}$. Santo Tomás "fue un tremendo humanista» ${ }^{86}$. Él hizo, en parte, a Dios interior al mundo. Casi todos los atributos divinos son asequibles a la razón. Esto a un cristiano de los primeros tiempos le hubiera parecido escandaloso.

El hombre recupera su confianza y el mundo su valor. «Casi todo el saber de los griegos sobre el mundo es reaprendido por los clérigos cristianos. Las Facultades de Filosofía comienzan a ponerse en primer término y a sombrar a las teológicas» ${ }^{87}$.

Esta plenitud es el tiempo del tomismo: «Había en éste llegado el hombre europeo a una armonía entre la fe y la razón, Dios y la naturaleza» ${ }^{88}$. Esa situación va a durar muy poco. El escotismo pensaba que se había producido una paganización de lo divino. Dios no es para esta escuela el conjunto de categorías provenientes del pensamiento griego y el racionalismo: En su auténtico ser, Dios es irracional e ininteligible. Por tanto, es ilusoria una ciencia teológica según el escolasticismo venía haciéndola. Con Ockam y los ockamistas de París se vive el fracaso de la razón lógica y conceptual para dar paso a la experimental. Poco a poco «El Dios irracional que se comunica burocráticamente con los hombres al través de la organización eclesiástica, va quedando al fondo del paisaje vital humano»" ${ }^{89}$.

La fe comienza a ser un credo quia absurdum. Se está muy lejos de san Agustín, san Anselmo o santo Tomás. Dios está fuera de la razón. Y puede hacer cuanto no sea contradictorio en sí mismo. Dios podía incluso tomar la forma de un asno ${ }^{90}$. Es el choque de la fe y la razón. Aquella se convierte en una confianza fiducial: «Sea lo que Dios quiera, porque Dios es eso: querer, voluntad omnímoda» ${ }^{91}$. Se desprecia al mundo, se desprecia la sabiduría. Es la devotio moderna. La religión sensiblera y la iniciación de la beatería, el

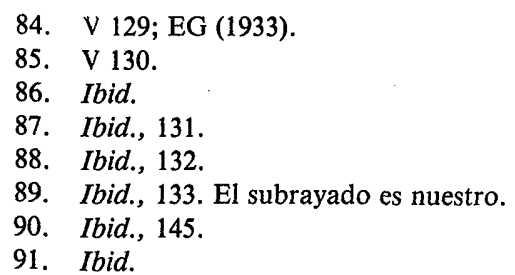


amaneramiento de la religión. Nadie se ocupa realmente de lo divino y comienza el desprestigio de los grupos religiosos: «Todo esto es el puro cristianismo medieval que se viene a tierra. ¿No es esa la situación religiosa del hombre moderno? Dios, al fondo" ${ }^{92}$. De nuevo Dios se ha escondido y ya no queda otra forma de llegar a él que la oración, para conocer su voluntad, es el camino de la profecía, la emunah-amén hebreo frente a la Naturaleza y el ser griego. Éste, por una parte, parece substante, substancia, ser, y por otra pseudo-ser ${ }^{93}$. A su vez «Dios, un auténtico Dios, no tiene ser, consistencia estable y fija: es pura y absoluta voluntad, ilimitado albedrío» ${ }^{94}$.

\subsubsection{Dios más al fondo}

A un Dios así no se puede llegar por un racionalismo naturalista. Es necesario buscarle por el camino de la vida, con la luz de la buena voluntad, donde brilla el conocimiento clarividente del amor. El amor se afana hacia el amado, está siempre en camino, de corazón a corazón, hacia la fuente de la vida: «No se puede ir al Dios que se ama con las piernas del cuerpo, y, no obstante, amarle es estar yendo hacia Él. En el amor abandonamos la quietud y el asiento dentro de nosotros, y emigramos virtualmente hacia el objeto. $Y$ ese constante estar emigrando es estar amando» ${ }^{95}$. Es un ir vacilante y peregrino, hacia donde, tan escondido; el amado mora.

Este estar siempre en camino no significa ningún tipo de ontofobia positivista o idealista. Es intentar llegar a lo que es. Pero con la precaución del que explora terrenos difíciles, y a veces peligrosos, donde el deseo de seguridad ante lo incierto puede jugar muy malas pasadas a la verdad auténtica y desnuda de la realidad. Bien lo sabía Ortega: «El afán de absoluto que lleva al hombre a construir las metafísicas, los sistemas del universo, no es un error. El error está en que crea poder lograrlo. Pero aún convencido de su imposibilidad, el hombre seguirá siempre imaginando lo absoluto; se trata de una función esencial a la constitución de su mente. Es decir, que los 'sistemas', degradados en cuanto a su pretensión, quedan y quedarán siempre como un hecho constitutivo de la conciencia humana» ${ }^{96}$.

Según Ortega, Aristóteles cree que todo es mundo, Descartes que todo es

92. Ibid., 149. El subrayado es nuestro.

93. Ibid., 536: «Apuntes sobre el pensamiento, su teurgia y su demiurgia», en Logos, Revista de la Facultad de Filosofía y Letras. Universidad de Buenos Aires (1941).

94. V 535.

95. Ibid., 556; SA (1941): «Facciones del amor», El Sol (7.1926). A Dios no nos acercamos andando, sino amando (S. Agustín).

96. VI 213; TAO (1942): «Guillermo Dillthey y la idea de vida», en Revista de Occidente 127 (1934). 
pensamiento. Sólo quien ha pasado por los dos los supera con sencillez. El conocimiento es hacer $\mathrm{y}$ des-hacer, atender $\mathrm{y}$ des-atender. $\mathrm{Y}$ en este proceso podemos distinguir en primer plano lo inmediato o las cosas; en segundo lugar el horizonte a la vista y en tercer término el más allá latente ahora. Esta latencia es relativa, «per accidens, como dicen en los seminarios» ${ }^{97}$. Dios ni es del todo arcano, ni privado de toda presencia, es como una frontera a la vez patente y latente. Es algo como visible pero a través de un velo y en enigma. Es lo divino 'en las cosas humildes', en los acontecimientos elementales, en el rito y en lo inválido donde 'casi es innecesaria' su existencia. Algo así como un Dios que se palpa en su ausencia ${ }^{98}$.

Como diría Kant, es el cielo callado que nos hace señales. No se trata en Kant de un pensador aldeano sino de un sabio poco dado a credulidades, y sin embargo «en 1788, resume todo su glorioso saber diciéndonos: 'Dios cosas hay que inundan el ánimo con asombro y veneración siempre nuevos y que se hacen mayores cuanto más frecuentes y detenidamente se ocupa de ellas nuestra meditación: el cielo estrellado sobre mí y la ley moral dentro de mí» ${ }^{99}$. El cielo, nos señala, parece querer decirnos algo con sus guiños. Así «la existencia gigante del Universo, de sus leyes, de sus profundidades y la ausente presencia de alguien, de algún Ser prepotente que lo ha calculado, creado, ordenado $\mathrm{y}$ aderezado... nos es una permanente incitación a trascender desde el mundo que es nuestro contorno al radical Universo» ${ }^{100}$.

Tal vez por esta experiencia todas las religiones localizan la divinidad y la avecinan entre las estrellas del firmamento. También el cristianismo lo hace así cuando reza 'Padre nuestro que estás en los cielos' ${ }^{101}$. Pero uno y otro mundo no coinciden radicalmente y aquí nos sentimos extranjeros o cuando nos sentimos seguros en este mundo nos hacemos como ajenos y extraños al otro de más allá: «somos, mutuamente, dos 'fueras' y por eso somos radicalmente forasteros» ${ }^{102}$. La filosofía es el heroísmo intelectual por mantener esta tensión sin caer, antes de tiempo, definitivamente, en uno o en otro mundo. No hay que hacer una ontología ni del uno ni del otro. La filosofía pide austeridad. No convertir el camino en posada. Ni echarse a dormir en un pliegue empírico trascendental de nuestra civilización como denunciara M. de Foucault. Por algo decía Fichte que filosofía es no vivir. No avecinarse en ninguna esfera filosófica definitivamente. Ni en el idealismo de otro mundo, sin más,

97. VII 121; HG (1949-1950).

98. I 467; POC (1916): «Renan» (4.1909).

99. VII 123; HG (1949-1950).

100. VII 123. El subrayado es nuestro.

101. VII 127; HG (1949-1950).

102. VII 126. 
ni en el realismo de este mundo, sin más. Tampoco hay que renunciar a la posibilidad metafísica. En esto hay que ser exigentes, lo demás es 'carrocería'.

Hay que actuar con cautela pero no caer en la suspicacia de todo. El positivismo fue una suspicacia de aldeanos. Hay que ser en todo lo que se es $\sin$ caer en los extremismos. Con un talante franciscano, y san Francisco decía: Yo necesito poco y lo poco que necesito lo necesito muy poco. El pensador debe evitar toda gesticulación cara al público. No puede convertirse en el 'mascarón de proa de sí mismo'. Por tanto: «El filósofo que está dispuesto al máximo peligro intelectual, que expone íntegro su pensamiento, tiene obligación de ejercitar plena libertad-librarse de todo, inclusive de esa suspicacia labriega ante una posible metafísica» ${ }^{103}$.

La metafísica, como la filosofía, no es algo superfluo. Pero si lo fuera, también lo superfluo es necesario. No hay contradicción entre la inmediatez de este mundo, entre la física y la meta-físicia. El hombre no renuncia a las grandes preguntas. No hay contradicción entre contemplación y utilidad, entre Marta y María; tampoco en el mundo biológico hay contradicción entre lo superfluo y lo necesario, lo indeterminado y lo determinado, entre el azar y la necesidad. Cuando tenemos un fragmento de la realidad queremos alcanzarla toda. Es el destino de la filosofía: «Su nota radical era buscar todo como tal todo, capturar el Universo, cazar el Unicornio... En todo ser dado, en todo dato del mundo encontramos su esencial línea de fractura, su carácter de parte y sólo parte - vemos la herida de su mutilación ontológica, nos grita su dolor de amputado, su nostalgia del trozo que le falta para ser completo, su divino descontento. Hace doce años, hablando en Buenos Aires, definía yo el descontento 'como un amar sin amado y un como dolor que sentimos en miembros que no tenemos'. Es el echar de menos lo que no somos, el reconocernos imcompletos y mancos» ${ }^{104}$.

Ese fundamento ausente, no es nunca trasparencia absoluta, es como una cierta co-presencia y una cierta ausencia que falta al mosaico del mundo, pero completamente otro, absolutamente exótico, imposible de avecindar del todo en este mundo: «el ser fundamental es el eterno y esencial ausente, es el que falta siempre en el mundo -y de él vemos sólo la herida que su ausencia ha dejado, como vemos en el manco el brazo deficiente» ${ }^{105}$.

En este sentido no se le puede hacer casero, pues: «Como en las religiones aparece bajo el nombre de Dios esto que en filosofía surge como problema de fundamento para el mundo, encontramos también en ellas las dos actitudes:

103. Ibid., 328; QF (1929).

104. VII 330-331; QF (1929).

105. VII 333. 
los que traen a Dios demasiado cerca y, como santa Teresa, le hacen andar entre los pucheros, $\mathrm{y}$, los que, a mi juicio con mayor respeto y más tacto filosófico, lo alejan y trasponen» ${ }^{106}$.

Dios se encuentra al fondo de las cosas y del mundo. Algunos han exagerado en exceso esta lejanía. El gnóstico Marción opinaba que Dios es 'lo absolutamente distinto y otro que el mundo', ni siquiera podría ser su creador ya que este mundo es imperfecto. Marción hizo del ser fundamental 'el Dios extranjero' '107, al que nadie puede alcanzar en absoluto. Pero a la vez que se subraya la distancia hay que descubrir la cercanía. El filósofo no busca el ser fundamental para ocultarlo y vivir en su obscuridad como ciertos místicos. La filosofía quiere claridad. Busca lo abismático para traerlo a lo claro. La filosofía es voluntad de mediodía y el filósofo dice como Goethe:

«Yo me declaro del linaje de esos

Que de lo oscuro hacia lo claro aspiran» ${ }^{108}$.

La filosofía quiere desvelar el ser, el secreto de las voces del silencio de la realidad. Ortega ve con preocupación las aventuras de los místicos y su bullanga. Comprende las precauciones de la Iglesia. No hay filosofía mística posible. Se pide más teología y menos éxtasis. El místico tiene su valor pero debe poder hacernos partícipes de su profundo viaje. Como dice el proverbio cuando se hace un largo viaje se trae algo que contar. En esta línea de claridad y trasparencia, de hablar de Dios y no de callar sobre él, Ortega nos confiesa lo siguiente: "Yo creo que el alma europea se halla próxima a una nueva experiencia de Dios, a nuevas averiguaciones sobre esa realidad, la más importante de todas» 109 .

No basta un Dios autónomo, es necesario el viaje de vuelta, la apertura al todo, lo que yo «llamo pantonomía» ${ }^{110}$. Ello no quiere tampoco decir que se tome el mundo como sensorio de Dios para caer en un sensualismo naturalista pagano al estilo de Aristóteles. Para Ortega: «Que un hombre así se haya convertido en el filósofo oficial del catolicismo es uno de los hechos más extraños, más confusos de la historia universal. Con decir lo cual no se mengua un ápice a la exuberancia de su cinglado genio" " ${ }^{111}$. Según Gilson los cristianos se fueron al platonismo por ser mál fácil de adaptar, pero santo Tomás no hizo esto. Ortega no cree identificable la filosofía cristiana con ninguno de los dos. El

106. Ibid., 333-334.

107. Ibid., 334.

108, Ibid., 342.

109. Ibid., 343.

110. Ibid., 336.

111. VIII 166-167; IL (1947). 
ockhamismo también exageró con su cristianismo nominalista. «La verdad es que, con estas cerrazones mentales, lo que hubiera sido la auténtica y original filosofía cristiana ha quedado nonato, y con ello ha perdido la Humanidad una de sus más altas posibilidades» ${ }^{112}$.

No es posible mundanizar trivialmente lo divino como hizo cierta escolástica y vivieron determinados grupos religiosos. No es posible confundir a Dios con la comedia del mundo. «No se oponga a todo esto que Aristóteles en su doctrina del Ente u Ontología se ocupa de Dios. Porque sobre ser, como nadie ignora, sobremanera discutible si al hacerlo no cometió Aristóteles una inoportunidad científica, acontece que su Dios ontológico no tiene nada que ver con el Dios religioso, ni con el griego ni con el cristiano. El Dios de la ontología es un principio de la mecánica aristotélica, algo así como la ley de la gravitación newtoniana. No tiene más papel que mover el mundo, tirar de él fuera y delante de él. Mucho más, pues, que al Dios cristiano o al griego, se parece a un tractor 'ocho cilindros' o a un pachón de asador que hace girar la espetera del Universo donde somos nosotros la asada volatería»" ${ }^{113}$.

Ortega acusa a Aristóteles de no admitir los realidad de los contrarios en el Uno, como hace Platón, y fomentar así 'el principio de la inercia ontológica' ${ }^{114}$ base del eleatismo triunfante, del olvido de Heráclito y de la falta de atención a la teoría de la creación continua de Descartes que supone que cada cosa es y a la vez no es ${ }^{115}$. La realidad misma, de suyo, es a la vez rica y contradictoria mientras que el escolasticismo es exacto, indiscutible. Se reciben las soluciones sin ver los problemas. No es un pensamiento vivo y los receptores ya no ven los auténticos problemas. Se dedican a endurecer la piedra, como decía Kepler, para que así queden ocultos los problemas vitales ${ }^{116}$. Ello no impide reconocer el esfuerzo tremendo del escolasticismo, nunca superado en otra época histórica. Ortega lamenta los pobres resultados de ese grandioso esfuerzo: «Confieso que no he podido nunca asistir sin pena, sin temblor de humana compasión al espectáculo ofrecido por estos cristianos medievales que viven hasta la raíz de su creencia religiosa, que chorrean fe en Dios, extenuándose en ver si logran pensar a su Dios como ente. Se trata de una fatal mala inteligencia. Porque el Dios cristiano y el Dios de toda religión es lo contrario de un ente, por muy realissimum que se le quiera decir.

La Ontología es una cosa que pasó a los griegos, y no puede volver a pasar a nadie. Sólo cabrán homologías. Poco después de 600 años antes de Cris-

112. VIII 167 nota 1.

113. Ibid., 219.

114. Ibid., 206 nota 2.

115. Ibid.

116. Ibid., 216. 
to, algunas minorías excelentes de Grecia comenzaron a perder la fe en Dios, en el 'Dios de sus padres'. Con esto el mundo se les quedó vacío, se convirtió en un hueco de la realidad vital. Era preciso llenar ese hueco con algún sustitutivo adecuado. Son una serie de generaciones ateas hastas 440 a.C., aproximadamente, en que empieza su nuevo apostolado Sócrates. Esas generaciones ateas, para llenar de realidad el mundo, vacío de Dios, inventan el Ente. El Ente es la realidad no divina, y sin embargo, fundamento de lo real. No cabe, pues, mayor quid pro quo que querer a Dios como ente. Como esto es imposible, en el pensamiento medieval, Dios, comprimido dentro del Ente, rezuma, rebosa, estalla por todos los poros del concepto de ente. De modo que se dio esta endiablada combinación: Dios que se había ausentado, vuelve a instalarse en el hueco que él mismo dejara; pero se encuentra con que su hueco está ya ocupado por su propio hueco. Este Dios habitando el vacío de Dios es el ens realissimum. Con lo cual aconteció que ni podían pensar de modo congruo el Ente, ni podían pensar idóneamente su Dios. Ésta es la tragedia que se titula 'filosofía' escolástica»" ${ }^{117}$.

El griego era incapaz de entender algo como ser creado. Todo ser para él es ser por sí. Tampoco Plotino lo entiende y se inventa la emanación. Santo Tomás usa la palabra. Para Ortega se trata de un desliz. «En la creación, el ser creado tiene un ser completamente distinto del ser creador, puesto que decirnos que hemos sido hechos 'a imagen y semejanza de Dios' no es sino una manera suavísima de decirnos que 'somos infinitamente dispares de El'; en cuanto al ser emanado tiene el mismo ser del emanante es su irradiación y nada más» ${ }^{118}$. El ser del griego vive en 'absoluto reposo ontológico'. «Pero el ser, que en tanto que ser se halla en marcha, está en cada instante dejando de ser lo que era, y pronto a ser lo que no era, a saber, lo otro" ${ }^{119}$. El ser en marcha hacia lo otro y el concepto de creación incluyen el cóncepto de la nada, de dejar de ser, que es lo más original que ha creado el hombre: «El concepto de Nada no puede sacarse de nada. Es la mayor invención humana» ${ }^{120}$. Se trata de un monstruo lógico. En cambio el Ente es un concepto omnibus, un transatlántico en el que entra todo mundo y nadie está a gusto. Su trascendencia, no su utilidad ni su inmediatez, nos lleva al ser de las cosas.

Aristóteles sólo ve las cosas como sustancias y no como relaciones. Esto lo hace Descartes y crea el pensamiento moderno. La filosofía perenne ve la

117. Ibid., 216-217.

118. XII 172; SRH. La razón histórica, Buenos Aires (1940).

119. VI 410; Prólogos (1914-1943): «A 'Historia de la Filosofía' de Emile Bréhier», Buenos Aires (1942).

120. VIII 230; IL (1947). 
analogía como relación pero no saca las consecuencias, según Ortega. Y debería hacerlo para comprender la modernidad y el pensamiento contemporáneo, en otro caso no es filosofía perenne sino petrefacta, tal vez la 'piedra filosofal' ${ }^{121}$.

El que, desde Descartes, haya una sola mathesis universalis que abarca desde la metafísica a la mineralogía no da derecho a confundir unas realidades con otras, o a dejar de situarlas cada una en su apropiado nivel, o a prescindir de explicar el método apropiado a cada realidad: «La continuidad de la materia científica no exime de distinguir en el corpus deductivo integral una región primera y fundamental que da cimiento a todo lo demás: es la Metafísica. Se ocupa del alma y de Dios» ${ }^{122}$.

Al menos, el racionalismo se enfrenta al sensualismo. Kant habla de los que recurren populacheramente a la experiencia, a la evidencia ontológica de los sentidos. Pero frente a la doxa la filosofía es paradoja. El sentido común es la demagogia escolástica. También el estoicismo recurre a la asunción colectiva. Según Ortega, una cosa cómica de Menéndez Pelayo es que creía una hazaña haber emigrado de la escolástica al sentido común de la filosofía escocesa que es como «salir de Malagilla para entrar en Malagón» ${ }^{123}$. La evidencia es algo que se me impone, con-vence, pero a la vez la voy capturando, y comprendiendo. Como en Cicerón, escoger una cosa es ser sobrecogido por ella ${ }^{124}$.

Aristóteles cree en la fehacencia sensorial. El escolástico cree moverse en la evidencia del Ser. A Ortega eso le parece una altanería momificada producto de una credulidad intelectual que no se ha contrastado realmente con el drama de la vida. Pues la filosofía se origina como necesidad de un incrédulo, es decir, del que no está seguro y duda de la credulidad recibida: «Filósofo sólo puede ser quien no cree o cree que no cree. (Ni que decir tiene, este creer cabe y hasta es una aventajada virtud, dentro de la fe), y por eso necesita absolutamente agenciarse algo así como una creencia. La filosofía es ortopedia de la creencia fracturada» ${ }^{125}$. La filosofía es una ciepcia que debe hacerse, no está ya hecha. Como decía Aristóteles, es la ciencia que se busca. La quebradura de las creencias hace ponerse en duda a Descartes. El Dios que recibe de Scoto y los ockhamistas ya no se atiene al sentido común, aunque sí a la Lógica. Es un Dios libérrimo, y poco a poco se sustrae a toda coerción humana. «Puestos a hablar de Dios, nosotros no guardaríamos ese respeto a la lógica, que viene a

121. VIII 239.

122. Ibid., 241.

123. Ibid., 249 nota 2.

124. Ibid., 252 nota 1.

125. Ibid., 261-262. 
ser otra diosa coercitiva de Dios, puesta a su vera con antipático talle de institutriz, para no permitirle contradecirse, con lo que se deja en la idea de Dios un postrer saborete de politeísmo y paganidad. Conviene hacer constar que el fundador del racionalismo creía en un Dios irracionalista, una de cuyas misiones, nada parva, es no dejar dormir a los profesores de Lógica. Así son los hombres de verdad: no se preparan los problemas preconcebidamente y no torean toros embolados. El Dios de Ockam y Descartes no había creado un mundo como el de Aristóteles o el que pronto veremos en Leibniz, ad usum delfinis, suponiendo como delfines a los hombres de ciencia. No había creado un mundo de antemano inteligible. Había dejado al hombre lleno de fe en Dios, pero lleno de dudas sobre el mundo»" ${ }^{126}$.

Así, Descartes se había visto obligado a 'dudar de todo. La nueva filosofía sería la que habría que hacer, la que se debía buscar sin haberla encontrado aún. Esto no es malo para el pensamiento pues la duda y el escepticismo del principiante es el barómetro que mide la presión filosófica: «Tanto de duda -se entiende, precisa y clarividente-, tanto de filosofía» ${ }^{127}$. El dogmatismo, por el contrario, es asepsia y analgesia. El filósofo debe descender a las profundidades de los problemas, de la realidad misma, con todas sus complicaciones actuales. Hoy es el sentido común y la evidencia misma lo que precisamente se discute y está en duda: «Los últimos siglos han vivido de fe en la 'cultura' - ciencia, moral, arte, técnica, enriquecimiento-, sobre todo de una sólida confianza en la razón. Esta teología cultural, racionalista, se ha volatizado» ${ }^{128}$.

Ahora la filosofía es la 'enajenación del mundo habitual'. El pensador es el hombre con más dudas auténticas pero también el mejor conocedor de la vida porque la vida es perplejidad: "Acontece que incluso el más creyente pasa la mayor parte de su vida en la incertidumbre, en la perplejidad; lo que prueba que no es imposible vivir perplejo... La perplejidad no es ocasional, sino que es una 'formalidad' constituyente de la vida. Podemos categóricamente decir que la vida es perplejidad» ${ }^{129}$. Siempre hay una realidad que me rebasa. Kant es el primero que reconoce que las uvas están maduras pero que no las podemos alcanzar: «Este es el 'tema' con que se abre el prólogo a la primera edición (1781) de la Crítica de la razón pura y que constituye el leitmotiv de toda la obra: 'La razón hưmana tiene... el destino particular de verse acosada por cuestiones que no puede apartar... pero a las que tampoco puede

126. Ibid., 263.

127. Ibid., 266.

128. Ibid., 280

129. Ibid., 290. 
contestar'» ${ }^{130}$. Ello no autoriza a llenar el vacío de Dios con un sucedáneo de lo sagrado, vgr. con el ente: «Pero es una concepto inconsciente, vano y decepcionante». 'Anuncio el jaque mate para el Ser de Platón, Aristóteles, Leibniz, Kant y aun Descartes' (IX, 394) ${ }^{131}$. Como lo dice santo Tomás, a Dios le conviene la categoría de sustancia pero no porque soporte accidentes sino en cuanto que es ens per se. Eso quiere decir que no está en otro. Además Dios no es ente, $\mathrm{y}$ «non habet quidditatem nisi suum esse» ${ }^{132}$.

La filosofía se sitúa frente al vulgo y sus creencias, frente al mundo que nos 'dementa'. Pero los filósofos no se quedaron en el desasosiego general de la inseguridad: «Buscaron la salida viendo lo Real como mero enigma, como acertijo y de aquí el estilo de descifradores de acertijos que adoptaron los fílósofos.

Pero es claro que echamos de menos una 'ciencia' que intente explicarse el Mundo y hallar su Ser verdadero, partiendo de considerar el engaño en que vivimos y que el Mundo nos es, como obra de alguien. Alguien h̀a querido que el hombre viva engañado. Hay un 'espíritu maligno'. El cristianismo, el mazdeísmo, el maniqueísmo, el cartesianismo, los hindúes, Schopenhauer han sido un conato de aquella 'episteme'»' ${ }^{133}$.

El hombre debe hacer filosofía, ser animal racional en ejercicio con toda la utopía y dubitabilidad que esto tiene. Como todo lo humano. La insensatez es un lugar comunísimo y cada uno debe oponerse a ella. El hombre es un animal hipotético y sólo será auténtico si consigue hacerse tal entre las dificultades. Antiguamente la divinidad parecía algo exuberante y claro. Después se redujo a causas del mundo y sus fenómenos. Con la filosofía, la pluralidad de dioses se reduce, es como un tiempo ateo: «Cicerón nos transmite que Antístenes en su Física dice: 'Populores Deos multos, naturalem unum esse' (De natura deorum, I, XIII)» ${ }^{134}$

En un tiempo movido por la inseguridad humana, el hombre atiende a lo divino. Ahora el mundo ya no lo necesita. También ahora el pensador se opone al vulgo, aunque oponerse a la doxa haga paradójico, como el profeta lo es contra el pueblo vgr. Amós. Por otra parte el filósofo da la impresión de saber demasiado y de quitar la fe, de descubrir los engaños porque se pone con valentía frente al Ser y a la incógnita del misterio y del mundo ${ }^{135}$. Ahora bien, el

130. Rubert de Ventos, X., Filosofía y/o política, Península, Barcelona 1984, 70, nota 14.

131. Guy, A., Ortega y Gasset y su puesto en la filosofía contemporánea, en Cuadernos Hispanoamericanos 403-405 (1984) 35.

132. SANTO TOMÁS DE AQUINO, Summa de veritate catholicae contra Gentiles, Madrid 1770, Lib. I, cap. XXV. BO.

133. VIII 295-296; IL (1947).

134. IX 420; «Origen histórico de la ocupación filosófica» (1943-1953).

135. IX 426ss. 
pensador no es principalmente testigo sino buscador de la verdad. Lo otro sería querer demostrar que dos y dos son cuatro a base de matar o dejarse matar: «No, no; el filósofo no puede dejar 'sin trabajo' al mártir usurpándole el oficio. El martirio es testimonio del hecho que es la 'creencia' pero no de la utopía sutilísima que es la Verdad» ${ }^{136}$. En esțo no está de acuerdo, tampoco, Ortega con Kierkegaard.

El hombre no puede ser chabacano y hacerse sordo a lo divino. Tiene con él una auténtica polémica. Así se han fraguado las grandes ideas entre los científicos y entre los pensadores. Kant sólo se entiende bien como polémica frente a Leibniz y Hume. «La creación, en fin, el hecho más ilustre que se conoce, no es fácilmente inteligible si no se considera como resultado de una divina polémica anterior a los tiempos, entre el principio del bien y algún otro principio oscuro de avieso y contradictorio natural» ${ }^{137}$. La realidad no es lo estático, lo eterno muerto: «En un universo de cosas eternas un Dios creador no encuentra trabajo. Y confesemos que, en efecto, el Dios de Aristóteles es casi, casi un atorrante» ${ }^{138}$. Es necesario rescatar para la filosofía la idea de creación a fin de avanzar en la comprensión dinámica y no cosista de lo divino. La vida es radical inseguridad, no pertenece al orden de las cosas. «Para encontrar en Aristóteles un concepto que nos sirva, que sea adecuado para pensar la realidad que es mi vida, tenemos que recurrir a lo que para él constituye la consistencia exclusiva de Dios: la pura enérgeia, la pura actuación o actividad, la absoluta agilidad. Pero mi vida no tiene la pretensión de suplantar a Dios ni de ser divina» ${ }^{139}$.

Mi vida está siempre dada en una circunstancia con sus facilidades y dificultades. Con una circunstancia que en gran parte es hostil, por eso decimos que no estamos ya en el Paraíso. Estamos como arrojados al mundo. Dios en cambio vive en sí mismo, no está limitado por fuera, porque no tiene fuera. Nada tiene que le resista, hiera o contradiga: «Por eso, hay que decir de Dios que existe solitario, que está sólo con sus pensamientos, con sus designios inescrutables, que está propiamente sin que haya cosa alguna en su derredor, en ningún efectivo fuera, sino que está solo consigo, dentro del elemento de sí mismo, en sí mismo como elemento, flotando en el océano de su propia intimidad; por tanto, sin preocupaciones ni ocupaciones, absorto en sí mismo, tejiendo perpetuamente la urdimbre misteriosa de sus meditaciones. Dios es, en absoluto, meditador; el soñador eterno que habita su propio ensueño infinito.

136. VIII 316; IL (1947).

137. X 39; «La conservación de la cultura», Faro (8.3.1908).

138. XII 173; SRH. La razón histórica, Buenos Aires (1940).

139. XII 206. 
Yo como filósofo y en este primer paso de mi filosofía no sé si hay ese Dios» ${ }^{140}$. Es una idea de Dios para explicar que el hombre es lo contrario, el que se afana, el que tiene que hacerse su vida. El verdadero conocimiento humano no vive de sí, sino de otra realidad ajena que no es él mismo: «El pensamiento tiene, para alcanzar al radical extranjero que es el ser, que es lo real, que restarse a sí mismo, ironizarse, quitar o, como ustedes dicen, sacar de la realidad lo que él ha puesto en ella, que es siempre una falsificación de ella, porque es, cuando menos, una exageración» ${ }^{141}$.

El hombre conoce la realidad pero, çomo dicen los argentinos 'hasta por ahí no más', la conoce, más o menos, no realmente. Así abandonamos Parménides: «Por eso necesitamos y hemos elaborado una ontología no eleática, como Einstein ha creado una física no arquimédica y no euclidiana» ${ }^{142}$. El eleatismo, el naturalismo, el idealismo, es como el barbo, del buen burgués, amaestrado para que pique. Así cogemos lo que tiramos, sacamos lo que ponemos antes en la realidad.

He aquí una de las claves básicas del pensamiento orteguiano, en metafísica y en religión, claramente vinculado a la ciencia más que a otras influencias filosóficas. Ortega acepta claramente las teorías de su amigo el einsteniano H. Weyl, y el mundo abierto de la física contemporánea.

Pero la ciencia no es la creencia, ni la vida. Son las creencias la arquitectura de la vida. Ésta no es naturaleza, es historia. Ahora ya, la razón no puede ser naturalista sino histórica. Hay que suprimir las teorías naturalistas. Al positivista le irrita que tengamos idea de lo que no conocemos del todo. Pero siempre hay en el conocimiento una dialéctica entre presencia y ausencia, entre fenómeno y noúmeno que dijera el genial Kant, entre la 'intención significativa' y el 'cumplimiento de significación'. «Para calibrar, pues, el interés de este asunto me bastaría con decir a ustedes que desde 1901 la filosofía de todo el mundo no hace sino moverse en torno, en contra o en pro de esa distinción de Husserl» ${ }^{143}$. En la intención significativa nos referimos a algo, en el cumplimiento de significación ese algo nos es dado inmediata y directamente. Esa dialéctica es un abismático problema, el enigma del Universo.

También el positivista tiene este problema aunque muchos no lo quieran ver: «Por mi parte podría anticipar, con la natural inexactitud que traen consigo las fórmulas harto breves, podría anticipar el $\alpha$ y el $\omega$ de mis convicciones 'lógicas o metodológicas diciendo: positivismo absoluto contra parcial positi-

140. Ibid., 208.

141. Ibid., 234. El entendimiento debe vaciarse a sí mismo para dejar transparentar la realidad.

142. Ibid.

143. Ibid., 400; IP (1914-1916). 
vismo. Deducciones, teorías, sistemas son verdad si cuanto en ellas y ellos se dice ha sido tomado por visión directa de los objetos mismos, de los fenómenos mismos... Tenemos, pues, sobre presencia y ausencia, el modo de referencia, en que en mí no hay del objeto sino 'mi referencia a él'» ${ }^{144}$. Es como mentarle algo a uno. En las menciones el objeto sólo está como alusión y referencia. De ahí que en toda verdadera ciencia hay siempre una preocupación por los fundamentos.

Adelantemos que un especialista orteguiano afirma que el mayor problema de la filosofía de la religión en Ortega con respecto al catolicismo es la liquidación de la categoría de 'sustancia' y su sustitución por la de 'acontecimiento'. F. Goyenechea no ve ningún obstáculo al catolicismo en su doctrina de la 'realidad radical' pero cree que es inconciliable «el catolicismo y la negación de las sustancia» ${ }^{145}$. Todo lo demás sería conciliable según el mismo autor. Pero esta reforma es la que Ortega considera necesaria, ya que en las ciencias no hay ya partículas identificables, según los textos orteguianos citados más arriba, y además la ontología eleática sustancialista tiende a desaparecer ante el dinamismo de la ontología relacional. No hay ya cosas sino momentos y procesos de la realidad que nos es en sí misma enigma. Semejante situación en la teología está anunciada por el término kairós, usado ampliamente por K. Barth y R. Bultmann, traducido generalmente por 'acontecimiento'. El deseo de Ortega es evidentemente modernizar la religión.

\subsection{El Misterio DE Dios Y El CRISTIANISMO}

\subsubsection{El Misterio de Dios en el misterio del hombre}

No solamente Dios hace al hombre a su imagen y semejanza, -como dicen algunas tradiciones religiosas - sino que también el hombre trata de hacer a Dios a su manera. Las concepciones religiosas tienen su tiempo y circunstancia. El hombre basado en la objetividad naturalista piensa a Dios como un ser objetivo, idéntico al mundo natural, como una veracidad absoluta, sin cualidades de intimidad y subjetividad. Así Spinoza nos habla de Dios como Naturaleza: Natura sive Deus ${ }^{146}$.

La fe del carbonero cree a Dios como un padre barbudo y cejijunto. El hombre culto ve en esa imagen un símbolo y un alegorismo y se complace en ella ${ }^{147}$.

144. XII 399.

145. GoYenecheA, F., Ateísmo e historicismo: Ortega y Gasset, en El ateísmo contemporáneo, II, Cristiandad, Madrid 1971, 375; 374.

146. I 445; POC: «Renan» (4.1909).

147. I 453. 
Otros se complacen en ubicar el Paraíso en distintos lugares según sus propias opiniones y contraponerlo a la tragedia del vivir humano con sus hostilidades y dificultades cotidianas ${ }^{148}$. Así ese paraíso se echa en falta en todas partes y en todos los sitios.

Como dijo el poeta antiguo: los blancos hacen a los dioses blancos, los negros dioses negros, los amarillos de color amarillo; y si los leones pensaran harían a los dioses como leones, los caballos como caballos y los elefantes como elefantes.

Lo mismo el hombre cree glorificar a Dios de las más diversas maneras hasta sorprender todas las previsiones: «Cuando el cristiano medieval quería alabar a Dios muy especialmente, mataba judíos ${ }^{149}$. El judaísmo ha tenido siempre una trayectoria muy especial en la que se implican lo humano y lo divino: «No acabaría de hablar nunca sobre los judios, ni creo haya tema más delicado para la sensibilidad de un poeta que este milenario dolor de un pueblo que eligió Dios una vez como vaso en que contenerse. ¡Pobre Yahvé magnífico, dios de la inquietud y de la melancolía que tenías el fuego en la una mano y el maná en la otra y te ponías a arder en las retamas al borde de los caminos!, aún la policía rusa azuza un pueblo imbécil, todavía no purificado por la palabra cáustica de los profetas, sobre las gentes de tu elección. ¡Qué horror!... ¡Pobre Yahvé según Nietzsche, has venido a ser el dios de todos los barrios bajos del mundo!» ${ }^{150}$.

Con frecuencia se repite la palabra 'Dios' como si todo el mundo estuviera de acuerdo en su significado concreto. Lo mismo ocurre con el hombre: « $i$ El hombre, el hombre! No hacemos sino repetir esta palabra como si pudiéramos asegurar de antemano que todos, al pronunciarla, nos referimos a lo mismo» ${ }^{151}$. Pero las palabras son vehículos de muy diverso contenido. A Montaigne le parecía el hombre un ser ondulante y vario. Nosotros sentimos perplejidad ante él como ante lo divino: «Parece cosa fácil, señores, decir qué es el hombre; parece que basta con fijar en él la mirada y dar un grito: ;Eccehomo! ¡He ahí el hombre! Y, sin embargo, ¿recordáis la dolorosa lámina? Una dulce figura esbelta y pálida, medio desnuda, manando hervor religioso, temblando y ardiendo interiormente de caridad. Al contemplar el pobre pueblo enfurecido, con pupilas de canes rabiosos, no ve en ella al hombre: ellos quieren al otro, a Barrabás, y el que les presentan es para ellos éste. Los fariseos tampoco vislumbran el hombre; ven sólo un heterodoxo, un sacerdote de

148. Ibid., 493 .

149. Ibid., 525; POC: «Shylock», II, (7.1910).

150. I 526-527.

151. Ibid., 509; «La pedagogía social como programa político». Conferencia (12.3.1910). 
una nueva divinidad matutina que por Oriente se levanta como un lirio celestial. Los soldados romanos, ceñidos de bronce, apoyados sobre los anchos escudos labrados, ven sólo un esclavo de cuerpo débil, tez tostada y aguileña nariz: un hebreo, en suma: es decir, un hombre de segunda clase, exento de ciudadanía: para ser plenamente hombre hay que ser, cuando menos, romanus civis, ciudadano romano. Andan por la turba, llenos de espanto y angustia, algunos pescadores galileos a quienes Jesús había prometido el reino siempre azul que se abre más allá de las nubes: ven un Dios. Pilatos mismo, en fin, que ha dicho 'He ahí el hombre', entiende por homo lo que en caso análogo entendería cualquier gobernador civil: el hombre aquel es un caso jurídico, un acusado, una cuestión de orden público.

Ved que no bastaba mostrar la esbelta y pálida figura para que las gentes se pusieran de acuerdo respecto a lo que veían: el hombre fue según quien le miraba Éste, un heterodoxo, un judío, un Dios, y un reo» ${ }^{152}$.

Para unos el hombre es un animal que bebe sin sed y hace el amor en todo tiempo, "para Leibniz, en cambio, es el hombre, un petit Dieu» ${ }^{153}$. Un Dios de ocasión. Así entramos en lo humano con un signo de misterio, con un religioso respeto. También a Hegel le fascinó el símbolo cristiano: «Cristo es, según él, el ensayo más enérgico que se ha realizado para definir al hombre.

La historia entera, señores, la historia política especialmente, no es otra cosa en su última sustancia que la serie de luchas y de esfuerzos por la definición del hombre» ${ }^{154}$.

Antes de humanizarse Dios sólo parecían estimables los genios: «pero al encarnarse Dios la categoría del hombre se eleva a un precio insuperable; siDios se hace hombre, hombre es lo más que se puede ser» ${ }^{155}$. Ya no hay separación entre el cielo y la tierra, entre lo humano y lo divino, entre la virtud y la sensibilidad, entre la ciencia y la religión. No hay pues, lugar a la división ni a la preferencia absoluta: «No, no prefiramos; mejor dicho, prefiramos no preferir. No renunciemos de buen ánimo a gozar de lo uno y de lo otro: Religión y ciencia, virtud y placer, cielo y tierra... Cierto que hasta ahora no se han resuelto las antítesis: pero cada hombre debe pensar que es él el llamado a resolverlas» ${ }^{156}$. La catedral de Sigüenza, en su equilibrio arquitectónico sereno, es el símbolo de la vida que cobra todo su sentido cuando es plenitud en todas las dimensiones de lo humano y lo divino. El hombre es aquel ser en el que la ma-

152. I 510-519.

153. Ibid.

154. Ibid.

155. Ibid., 520.

156. II 46; E I (1916): «Tierras de Castilla» (1911). 
teria se espiritualiza. También en él el espíritu se hace presente en corporalidad. No hay oposición. Al describir el cuadro del Greco, Apocalipsis, que tenía Zuloaga en su estudio de París, nos dice Ortega que es una visión postrera de la materia por un espíritu que se consume en su propio fuego. Un viejo joven, san Juan, levanta las manos en ademán equívoco de evocación y espanto: «Y tras él, bajo una gran batalla que riñen en lo alto las nubes, cuerpos desnudos y flameantes que aspiran a volatilizarse y sumirse en aquel drama aéreo y semiespiritual de los cielos» ${ }^{157}$. Es el tema eterno de la materia que arde en el fuego del espíritu, el cuerpo que se consume por el amor.

Tampoco hay oposición entre la muerte y la vida. Una da ruso a la otra. Así lo dice el san Mauricio del Greco. La legión tebana se niega a reconocer las divinidades del paganismo y muchos soldados sufren el martirio. San Mauricio reúne a sus compañeros y les felicita por su disposición a morir por la fe de Cristo. Es todo un tratado de ética. Hombres mortales, conspiradores de su propia muerte. «Este momento, la vibración esencial de estas palabras, constituyen el tema del Greco. Es un grupo de hombres ensimismados, y, sin embargo, en profunda conversación y comunicación. Parece que ha descendido cada cual al fondo de sí mismo y ha encontrado allí a los demás» ${ }^{158}$.

La vida humana misma es camino y es hogar. Es felicidad y es fugacidad. La vida es un viaje decían los ascetas antiguos y apuntaban a la eternidad. Desde la tierra al cielo. Las cosas cuando vienen ya se van: «Porque es una pena esta manía de huir que las cosas tienen. 'A la manera que no se podría gozar - dice el Padre Nieremberg - de la vista de un bizarro jinete lleno de joyas y de galas, si fuese siempre corriendo a rienda suelta, así tampoco de las cosas de esta vida se puede gozar bien, porque no paran en un punto, corriendo a rienda suelta'» ${ }^{159}$. Pero ahí éstá precisamente su encanto. En que lo pequeño tenga tanta importancia para el hombre. No es que no valgan nada, como concluye Nieremberg en su Diferencia entre lo temporal y lo eterno. Esto sería la fábula de la zorra y las uvas, despreciar lo que no se puede retener. Ortega piensa así: «¡Hombre, no! Despreciables, no; todo lo contrario. Precisamente porque son las cosas maravillosas, su huida apresurada nos deja en el corazón cicatrices. Si las cosas todas fueran dolores de muelas, la fugacidad de la vida sería su mayor mérito» ${ }^{160}$.

Ahí está precisamente la cuestión. Cada época tiene su verdad, decía Hegel. La nuestra, según Ortega, se enfrenta a la difícil relación entre lo tempo-

157. II 154; E II (1917): «Muerte y resurrección» (1917).

158. II 151 .

159. Ibid., 247; E III (1921): «De Madrid a Asturias o los dos paisajes», España (1915).

160. II 248. 
ral y lo eterno: «De todos modos, el tema de nuestro tiempo - la unión entre lo temporal y lo eterno- no está resuelto en Hegel» ${ }^{161}$. Hegel defendía el eterno presente, para él la Historia es la historia del Estado. Por eso decía: «La aparición del Estado es la iniciación de una realidad nueva, sobrenatural; el anuncio de que nace un orbe cuya sustancia es Libertad. Es el orbe histórico o sobrenatural, cuya vida y evolución no consiste en más que en un 'progreso de la conciencia de libertad'» ${ }^{162}$. Así no se entiende que lo temporal sea sacramento de lo eterno, el tiempo y la historia camino a la eternidad y al futuro. Se confunde la realidad con la eternidad. El presente con el futuro. Lo transitorio con lo definitivo. Así se divinizan los sistemas y los Estados.

El hombre de hoy tiene que vivir entre la utopía y la realidad, entre el ahora y el futuro. Sin nostalgia y sin dramatismos, ante la cruda realidad. Sin traicionarse con verdades absolutas que no lo son: «El hombre no tiene más remedio que aprender a vivir en esta forma dual y sentirse a la par mudable y eterno. Esto nos obliga a modificar profundamente la óptica de la vida. Antes se interesaba el hombre en una forma de arte, en una idea científica, en un principio político, porque le parecían definitivos. Cuando no se lo parecían, caía en el escepticismo; que es la suspensión de la vida. Ahora necesitamos aprender que sólo somos definitivos cuando henchimos bien el perfil transitorio que nos corresponde, es decir, cuando aceptamos 'nuestro tiempo' como nuestro destino, sin nostalgia ni utopismos» ${ }^{163}$.

La vida ofrece su cara placentera como también presenta su dimensión de soledad. Es dulzura y es acritud. Tiene su mensaje amistoso y complaciente y, también, un aspecto hostil, torvo y desesperanzado. Defensivo y ofensivo. Igual que la fe tiene su ingenuidad y su experiencia satisfecha y lleva también a un compromiso con el mundo marginado, enfermo y roto. Es como esas monjitas de la Caridad que forman un «ejército tan noble, tan respetable, tan arcaico» ${ }^{164}$. Se necesitaría más ciencia y más caridad. Pero no siempre se apoya lo noble y auténtico: «Una vez más, el hombre excepcional, con la cruz de su esfuerzo a cuestas, cruza desapercibido la plaza pública, mientras sus compatriotas prefieren y aplauden a cualquier Barrabás» ${ }^{165}$. Era el lamento de Marañón ante el poco reconocimiento al psiquiatra, Nicolás de Achúcarro, del Patronato de Anormales.

En la vida, cada persona, queda definida por las cosas que necesita para

161. Ibid., 566; E VII (1930): «Hegel y América» (3.1928).

162. II 568.

163. Ibid., 728; E VIII (1934): «Revés de almanaque» (1930).

164. II 249; E III (1921): «De Madrid a Asturias o los dos paisajes», España (1915).

165. III 29; «Una pérdida nacional: Nicolás Achucarro», El Sol (26.4.1918). 
vivir. Por los instrumentos que maneja conocemos el oficio de cada uno: el fontanero, el médico, etc. El poeta vive de cuatro cosas sutiles: el hontanar, el cielo, la ribera y la nube o tormenta. $\mathrm{Y}$ «sobre todo con un poco de amoroso incendio y de fiebre hacia Dios, elabora sus canciones» ${ }^{166}$. Cada gesto, cada mirada, nos define y desvela, entero, el corazón: «Sin quererlo, al movernos ante el prójimo le referimos nuestras memorias. Y el ademán con que pretendemos encubrir algo íntimo es el grito más claro en que lo revelamos» ${ }^{167}$.

\subsubsection{Dios en el tiempo: El cristianismo}

El griego es mágico con las ideas. Le basta que exista la idea o el logos para que actúe y sea real. Ocurre a todos los pensadores griegos. El cristianismo es el realismo griego hecho carne y vida. Es decir, el idealismo inmenso de la inteligencia griega encarnado en el mundo conçreto: «Es un error considerar el realismo de las ideas como algo peculiar a Plạtón. En verdad, no hace sino heredar a Parménides y preceder a Aristóteles. En éste, la realidad máxima es la sustancia; pero la sustancia no es sino una idea que, como tal, tiene el poder mágico de plasmar la materia y de encarnarse. Cuando el Cristianismo sostiene en el Evangelio de san Juap que el verbo, el Logos, se hace carne, resume toda la Grecia clásica» ${ }^{168}$.

Pero el cristianismo tiene también diferentes versiones. Hay el ambiente del judaísmo y el medio griego-helenista. Con ser de una raíz común sus presentaciones son dispares: «La Iglesia de Jerusalén sigue enraigada en la tradición judía; la Iglesia de los gentiles se nutre de la atmósfera helenística. Resultado de este doble clima espiritual son los Evangelios» ${ }^{169}$.

En cuanto al sustrato del cristianismo, se le adjudica diversas procedencias según las tendencias de la investigación. Además de la cuestión helenística algunos plantean la cuestión babilónica (Reitzenstein, Meyer) que remítíáa a Persia y Babilonia. De todos modos se ha estabilizado bastante la investigación en torno a la redacción de los primeros escritos cristianos así como la relación de Jesús con la comunidad. La historia de las formas y los géneros literarios se ha impuesto aunque de vez en cuando aparezcan reticencias ${ }^{170}$. Hay además un acuerdo sustancial sobre el mensaje central del cristianismo.

No obstante, cada época tiene su propia aventura. Por ejemplo, en la Edad Media, san Alberto Magno y santo Tomás viven en el siglo XIII. El hom-

166. III 14; «Estafeta romántica», El Sol (27.1.1918).

167. III 15.

168. Ibid., 539; «Etica de los griegos», EL (1927).

169. III 523; «La forma como método histórico», EL (1927).

170. III 526-525. 
bre aparece entonces instalado en el mundo sin grandes dudas ni problemas. Cada uno sabe perfectamente a qué atenerse. Con unas cuantas ideas claras y suficientes para ese momento. Santo Tomás resuelve todo con el buen sentido. En este momento parece que: «La misión superior del hombre no es ser agudo, sino simplemente resolver su vida lealmente, sinceramente» ${ }^{171}$. Con las Cruzadas aparece el mundo árabe. Comienza así la batalla entre la ciencia y la religión. Santo Tomás heleniza el cristianismo por segunda vez. La primera ocurrió en Grecia misma. Se filtran en su médula elementos extraños, pues, lo griego traiciona la intuición cristiana. Sin cruzadas ni Aristóteles se hubiera formado una auténtica filosofía cristiana sin elementos espúreos orientales. Sin querer emitir un juicio definitivo, Ortega opina lo siguiente: «La filosofía cristiana sería una línea irreal que sólo podemos fijar en algunos de sus puntos: san Agustín, los Victorinos, Duns Scoto, Eckhart, Nicolás Cusano.

Que ahora se celebre a Alberto Magno como instaurador de la filosofía cristiana pudiera acaso juzgarse como un acto más en la tragedia del cristianismo, un extraño qui pro quo como otros que tristemente registra la historia» ${ }^{172}$.

Cuando llegó el cristianismo la situación era desesperada. Las clases superiores vivían sin sentido, del consumo lujoso. Las inferiores fermentaban. Pululaba una gran propaganda religiosa oriental. Los cínicos, con estaca y morral al hombro, gritaban contra los ricos. Tal es el panorama de las pseudoclementinas. En esos bajos fondos se meten los activistas cristianos. La consigna es: sólo vale el pobre.

Como siempre que hay crisis todo se vuelve de al revés. Si la riqueza no salva, salvará la pobreza. Si la sabiduría no resuelve los problemas habrá que acogerse a la ignorancia. Cuando en el siglo XV vuelve la crisis se hablará de docta ignorantia (Cusa), o de alabanza de la locura (Erasmo), o del elogio del asno en G. Bruno. Si las instituciones y la ley no funcionan se huye a la ilegalidad. El cínico y el proselitista cristiano se aproximan: La ciudad y la política no dan la salvación. Por afirmación del contrario se llegará a recibir muy bien: «la grande y auténtica innovación del cristianismo» ${ }^{173}$. Todo esto ocurriría, según el cristianismo: 'Para que, como está escrito: El que se gloría, gloríese en el Señor'.

Conviene, conviene de cuando en cuando recordar el pasado, recordar que se han dicho estas cosas. Un alto burgués del Imperio que oyera leer estos gritos manuscritos de san Pablo, ¿qué pensaría? Que era un poco subversivo,

171. V 90; EG (1933).

172. V 92.

173. Ibid., 103. 
¿no es cierto? $\mathrm{Y}$, sin embargo, eso que predicaba el cristianismo fue luego, según la frase tópica, el más firme sostén de la sociedad» ${ }^{174}$.

Santo Tomás y san Buenaventura pensaban que Dios es en buena parte inteligible y racional. Todo en Él era muy lógico. «Pero, ahí está, nosotros nos hallamos en una creencia opuesta y nos parece que santo Tomás y san Buenaventura padecieron una ilusión. Nosotros estamos ciertos de que Dios ha hecho el mundo, pero ahí acaba todo, porque al mismo tiempo, estamos ciertos de que no lo ha hecho por ninguna razón. Esto de la razón es ya cosa creada, humana y un instrumento que poseemos para habérnoslas con la naturaleza, no con la sobrenaturaleza» ${ }^{175}$. Dios ya no nos resuelve los problemas del mundo. Éste tiene su secreto y tenemos que enfrentarnos a él. Ya no basta con ser cristianos para tener todos los problemas resueltos.

Ahora ya no se vive esta vida como si fuera la otra. Ya no se reduce nuestra existencia a ocuparnos de Dios directamente. El cristiano antiguo vivía desde Dios y cara a Dios. Tocaba sólo las cosas por la tangente: «Mas nosotros, si bien seguimos viviendo desde Dios, lo hacemos cara a este mundo y sin viaje de vuelta. Venimos de Dios, pero éste queda a nuestra espalda, como el fondo habitual del paisaje: mas a lo que atendemos propiamente es a lo terrenal»" ${ }^{176}$.

La misma vita beata es un cuadrado redondo propuesto por el cristianismo consciente de su imposibilidad ${ }^{177}$. Un poco como pasa en el epicureísmo entre la ciudad y el campo, la comunidad humana y la amistad verdadera. Igual que la dinámica sutilísima entre contemplación y acción cristiana. Dios ya no es del todo accesible directamente: Es la sierra que cierra nuestro horizonte pero al que nunca se llega definitivamente en esta vida. Ante esta situación la religión no va a ser tanto teología, dogma, y creencias, cuanto conducta concretá en el mundo en cuanto tal.

Se inicia una nueva época: «La expresión es ésta: Imitación de Cristo. ¡Ah!, la vida que consiste en imitar a Cristo, $1 .^{\circ}$, se desinteresa de si Dios es de éste o del otro modo, en su propio ser, en su más allá. $2 .^{\circ}$, de la Trinidad segrega una sola persona: Cristo. $3 .^{\circ}$, de Cristo toma, no lo que tiene de persona trinitaria, sino lo que tiene de hombre ejemplar. He aquí, por qué curio-

174. Ibid., 106. Al principio el cristianismo presentaba unas expresiones extrañas, vgr.: "¿No hizo Dios loco el saber de este mundo?». «Y así, hermanos, ved vuestra vocación, que no sois muchos sabios según la carne, no muchos poderosos, no muchos nobles». «Y las cosas viles y despreciables del mundo las escogió Dios, y aquellas que no son, para destruir las que son». Y otras muchas citas del Nuevo Testamento hechas por Ortega en V 105; EG (1933).

175. V 146-147.

176. Ibid., 147. Subrayado nuestro.

177. IV, 53; «Filosofía pura. Anejo a mi folleto 'Kant'» (7.1929). 
so escamoteo, hemos llegado a una forma de religión en que, si se me entiende bien, hemos secularizado el cristiano, subrayando de Dios su única vertiente humana intramundana. No es, conste, que el hombre se vaya del cristianismo: es lo contrario, que el hombre trae el cristianismo al punto de vista y de acción humano. Por eso he hablado de secularización. $\mathrm{Y}$, en efecto, ipso facto surge en toda Europa un enérgico desdén religioso - nótenlo bien, ireligioso!contra la antigua figura de la santidad, de la vida perfecta, a saber: contra los frailes y, en general, eclesiásticos» ${ }^{178}$. Es la religión de laicos y para laicos propuesta por Tomás de Kempis. Es la devotio moderna y los Hermanos de la vida común. Se quiere tratar con Dios con verdadera humanidad: «Dios es para ellos ante todo el hombre Cristo - que ni siquiera es sacerdote. Y lo más notable del caso es que el título primitivo de la Imitación de Cristo era: De contemptu mundi.

Nada como esto - y por eso he empezado con ello- puede darnos una idea más aguda de que la vida va a cambiar su centro de gravitación; no es ya que frente a la religión se afirme el mundo y esta vida, sino que el mundo, en su especie de vida humana, se mete en la religión y la absorbe. La vida antigua fue cosmocéntrica; la medieval, teocéntrica; la moderna, antropocéntrica» ${ }^{179}$.

Ahora estamos alojados en este mundo y vivimos como en una disensión entre la vida y la fe. También el católico actual participa de esa ocupación primaria, naturalista, en las cosas del mundo. En cierta manera se está en algo que no se es. Se vive en hueco. Tanto en la religión como en la ocupación. «Y perdóneseme, pero no admito que me venga el católico de nuestro tiempo con aire petulante diciendo que a él no le cuesta ningún trabajo, porque él sigue siendo el hombre medieval... No coceemos contra el destino: es inútil. El hombre moderno y contemporáneo consiste, entre otras cosas, en arrastrar esa dualidad íntima y tener que atender al doble y opuesto imperativo de la fe y de la razón” ${ }^{180}$.

En la época anterior había como dos mundos bien distintos y separados: El cielo y la tierra. Uno mudable, el otro inmutable. La materia mudable y la forma inmutable. Incluso los estamentos sociales: obispo, religioso, casado, eran situaciones estables y permanentes. Personalidades sagaces, próximas a Nicolás de Cusa, admiten esta situación estática absoluta: «En el libro De doctrina et regulis vitae christianorum, de Dionisio el Cartujano, puede verse la definición absoluta y como para lo eterno de todas estas formas de la realidad humana con que siempre habrá que contar» ${ }^{181}$.

178. V 147; EG (1933).

179. V 148. El subrayado último es nuestro.

180. Ibid., 153.

181. Ibid., 160. 
A partir de la devotio moderna el cambio es muy fuerte. No aparece ya esa estabilidad perfecta e indiscutible. Sin la experiencia anterior no sería la época siguiente como es. Pero, precisamente, porque se trata ya de otras formas y maneras, lo anterior sólo queda ahora en la forma de lo que se ha sido. Influye aún en el presente, pero ya no es lo que fue. «El cambio radical consiste en que hacia 1400 el hombre deja de estar en el cristianismo. La estructura de su vida no es ya la estructura rigorosa de estar en la fe cristiana. Por vez primera en la evolución del destino europeo se advierte que la situación del hombre consiste en venir ya del cristianismo, en vez de estar en él. Y como todo aquello de donde se viene, queda a nuestra espalda. Este hombre del XV, como en forma mucho más acusada nosotros, ha sido cristiano. ¿Significa esto que lo ha dejado de ser? En modo alguno. ¿Lo que hemos sido ayer y anteayer lo hemos dejado en absoluto de ser, no pertenece a nuestra consistencia actual? Claro que pertenece, claro que seguimos siéndolo, pero precisamente en el modo del 'sido'»" ${ }^{182}$.

Las relaciones entre la filosofía y la teología también se subvierten. Cada una se independiza. La teología deja de ser un intento de adaptar la fe a la razón filosófica y que ésta admita la sin-razón o super-razón del misterio: «Mas la nueva 'teología dialéctica' rompe radicalmente con tan añejo uso y declara al saber de Dios independiente y 'totalmente' soberano. Invierte así la actitud del teólogo, cuya faena específica consistía en tomar desde el hombre y sus normas científicas la verdad revelada; por tanto habla sobre Dios desde el hombre. Esto daba una teología antropocéntrica. Pero Barth y sus colegas vuelven del revés el trámite y elaboran una teología teocéntrica. Él hombre, por definición, no puede saber nada sobre Dios partiendo de sí mismo y de su intra-mundana mente. Es mero receptor del saber que Dios tiene de sí mismo y que envía en porciúnculas al hombre mediante la revelación. El teólogo no tiene otro menester que purificar su oreja donde Dios le insufla su propia verdad, verdad divina inconmensurable con toda verdad humana $y$, por lo mismo, independiente. En esta forma se desentiende la teología de la jurisdicción filosófica. La modificación es tanto más notable cuanto que se ha producido en medio del protestantismo donde la humanización de la teología, su entrega a la filosofía, había avanzado mucho más que en el campo católico» ${ }^{183}$.

Cuando las cosas se complican el hombre puede sentir la tentación de una excesiva simplificación. El creyente puede citar, en ese momento, palabras de Jesús: 'En verdad, en verdad os digo que una sola cosa es necesaria'. Ó se pue-

182. Ibid., 151. 1930).

183. IV, 104-105. «¿Por qué se vuelve a la filosofía?», La Nación (Buenos Aires 21.1. 
de sentir el deseo de terminar con toda ley ya que el hombre se pierde en ella y su intrincamiento. San Pablo suena en esa dirección: Lo que importa es la fe; basta con la fe. "Y conste que con esto no hago luterano a san Pablo. Cuando dice que sólo la fe salva, claro está que lo que subdice es que la ley y las obras conforme a la vieja ley no salvan. Pero no excluye la necesidad de las obras para salvarse, se entiende de las obras que brotan de la fe, no las de la ley -las obras que caen del hombre creyente como los frutos del árbol que ha prendido en el huerto-” ${ }^{184}$.

Eso no quiere decir que el hombre sea dueño absoluto y señor incondicional de la salvación y de la vida. En tal caso su sueño de infinito produce mostruos y sus creaciones se vuelven contra él mismo. Debe, por tanto, ser consciente el hombre de sus propios límites: «Maravillosamente, el cardenal Cusano decía que el hombre, por ser libre, crea, pero es libre y crea inserto en el instante temporal, bajo la presión de la circunstancia: de aquí que merezca el título de Deus occasionatus, 'Dios de ocasión'»" ${ }^{185}$.

En épocas de crisis se tiende al extremismo. Algunos cristianos soltaron las amarras que les unían al mundo en el medioevo y se lanzaron a una mística, a una fe, despavorida. Es una salida a la desesperada. Y aunque la desesperación sea parte fundamental de la vida humana, nada humano puede llevarse adelante sin pactar con la realidad. Ortega mismo decía que nuestra existencia es algo que, en definitiva, no es nada. Pero eso es el origen y el diagnóstico de la crisis, no la solución. Eso fue el existencialismo: «El gran teólogo Paul Tillich no exageraba cuando afirmaba que el existencialismo ha logrado expresar el espíritu de nuestro tiempo mejor que cualquier otro movimiento intelectual. Ninguna otra filosofía del siglo $\mathrm{xx}$ ha tomado tan en serio el drama íntimo de nuestra crisis personal y colectiva, ni ha ahondado tanto en ese pavoroso vacío que llena el alma cuando el hombre descubre que no es nada». (Véase The courage to be. Yale University Press. New Haven, pág. 86-112) ${ }^{186}$.

Ahora bien, para superar algo hay que asumirlo y vivirlo. El extremismo solamente puede imponerse de modo pasajero. Si no, no sería extremismo. Pero cuanto más extremista sea un proyecto más fácil es que se imponga de momento. Para Ortega el cristianismo primitivo incurrió en algo de esto como se puede ver en su crítica a la sabiduría griega y en los fenómenos pararacionales del don de lenguas, y otros semejantes, contra los que finalmente, san Pablo discípulo, él mismo, tiene que luchar. «Recuérdese que san Pablo

184. V 110; EG (1933).

185. V 223; MB; Revista de Occidente (1935).

186. Dust, H.P., El extremismo existencialista a la luz de la razón histórica, en Cuadernos Hispanoamericanos 403-405 (1984) 141. 
daba a su fe deliberadamente un perfil de absurdidad y de locura, para hacerla más atractiva a los exasperados de su tiempo. En 1450, nada menos que el Cardenal Cusano proclamaba que la verdad razonable del hombre es constitutivamente lo que no es verdad —en cambio, la verdad de Dios, la verdad absoluta se caracteriza por el absurdo. En rigor el credo quia absurdum resuena siempre en el fondo visceral del cristianismo» ${ }^{187}$.

Es muy fácil caer en el anti-arte, la contra-cultura, el anti-racionalismo y el libertinaje cuando se pierde la fe en las cosas y ya no se cree en el mundo. «Hablando de Simón Mago y su movimiento religioso, dice en el libro Origen y comienzos del cristianismo el más grande historiador de estos últimos treinta años, Eduardo Meyer: 'El combate de san Pablo contra la ley llevó en muchas sectas que inmediatamente brotaron al más grosero libertinaje y a un completo desorden moral. En el movimiento de Simón aconteció esto naturalmente en grado sumo'. III, 285» ${ }^{188}$.

El azoramiento, la desorientación y el desequilibrio de los tiempos turbios lleva a personalidades como Paracelso o Savonarola. Nunca se sabe si son sabios o embaucadores. Son como las contradicciones de los renacentistas que un día son cristianos y otro naturalistas, luego vuelven al cristianismo. Surgen caracteres como M. Ficino que es una mezcla de estoicismo, fe y acedia. Estas épocas son también propensas a cambios muy fervientes y conversiones espectaculares. Estas situaciones son comprensibles, para Ortega, como reacciones, desde la realidad radical que es nuestra vida - lo único que realmente tenemos - ante el cambio profundo de circunstancia. Si ese cambio es exagerado la vida inmediata se siente amenazada y empujada hasta el extremo de buscar otra realidad. «Esa otra realidad aparece con los atributos absolutamente opuestos a la realidad humana natural: no tiene comienzo ni término, es intemporal o eterna, es principio de sí misma, omnipotente, etc. En suma: esa realidad es Dios.

Hecho este descubrimiento y desde esta creencia, nuestra vida será vivida por nosotros bajo una perspectiva nueva. Todo lo que ella es y lo que en ella hagamos, lo referiremos a nuestra verdadera realidad, esto es, a lo que somos ante Dios y en Dios. De este modo reabsorbemos nuestra existencia temporal en la eternidad de Dios. El hombre se dispone a vivir de espaldas a esta vida y de cara a la ultravida»" ${ }^{189}$.

El Renacimiento, a su vez, es una crisis lenta entre la experiencia medieval cristiana y gótica hacia la vida moderna, naturalista y barroca. Es la mar-

187. V 113; EG (1933).

188. V 114.

189. Ibid., 125 . 
cha de Dante, plenamente instalado en las creencias cristiano-escolásticas, hacia la modernidad definitiva descubierta luego en Descartes. El Renacimiento afirma al hombre y al mundo. «Se prepara 'la vuelta a la naturaleza', a la antehistoria, que Rousseau, con su característica irresponsabilidad, consumará. Se inicia la idea de una 'religión natural', de un 'derecho natural' y de una 'ciencia natural'. El hombre, se supone, está en posesión de un arsenal nativo de medios que le bastan. Se basta a sí mismo. Es - se cree otra vez suficiente, y no como al fin del mundo antiguo, indigente. Huelga Dios» ${ }^{190}$.

El caso de Vives, un hombre bueno, honesto y dulce representa el momento en que la Edad Media ya había muerto. Se va a abandonar la concepción sobrenaturalista y teocéntrica. El hombre, en aquella época es, como nada, un total fracaso: «Con sus propios medios va el hombre solo a la derrota y a la desesperación. Sólo puede salvarle el auxilio trascendente. Es maravilloso y conmovedor y ejemplar ver cómo entonces el hombre náufrago en su último y propio océano de nulidad, se agarra fieramente a la tabla flotante que es Dios» ${ }^{191}$.

Las ciencias no podían solucionar el problema. Ellas solamente tratan sobre las cosas; pero el hombre no es una cosa sino el constante esfuerzo por no dejar de vivir. $\mathrm{Al}$ hombre no le llegan las ciencias naturales porque él no tiene naturaleza: «Mal podía la razón físico-matemática, en su forma crasa de naturalismo o en su forma beatífica de espiritualismo, afrontar los problemas humanos. Por su misma constitución, no podía hacer más que buscar la naturaleza del hombre. Y, claro está, no la encontraba. Porque el hombre no tiene naturaleza. El hombre no es su cuerpo, que es una cosa; ni es su alma, psique, conciencia o espíritu, que también es una cosa. El hombre no es cosa ninguna, sino un drama - su vida, un puro y universal acontecimiento-. Todas las cosas, sean las que fueren, son ya meras interpretaciones que se esfuerza en dar a lo que encuentra» ${ }^{192}$.

\subsubsection{La humanidad y la fe historializadas}

La vida es experiencia de vida. Esa experiencia es pasado vigente. Pero el hombre es ontológicamente irreversible, no puede 'volver a ser lo que ha sido'. El ser del hombre es 'ser lo que no ha sịdo'. «Y como el término 'ser' está irresistiblemente ocupado por su significación estática tradicional, convendría libertarse de él. El hombre no es, sino que 'va siendo' esto y lo otro. Pero el concepto 'ir siendo' es absurdo: promete algo lógico y resulta, al cabo, per-

190. Ibid., 497; «Vives», La Nación (Buenos Aires 12.1940).

191. V 497.

192. VI 32; HS (1935). 
fectamente irracional. Ese 'ir siendo' es lo que, sin absurdo, llamamos 'vivir'. No digamos, pues, que el hombre es, sino que vive» ${ }^{193}$.

La temporalidad es una de las gracias de lo humano. El hombre siempre es un heredero, nunca estrena la humanidad, nunca es ya eterno Adán como el primero sino segundo o tercer hombre. «Tiene, pues, su virtud y su gracia ontológica la condición mudadiza, y da ganas de recordar las palabras de Galileo: I detrattori della corruptibilità meriterebber d'esser cangiati in statue» ${ }^{194}$. Es la historia la que forma el sistema en que se articula la experiencia y cada concepto humano. «Es imposible entender lo que es este hombre 'racionalista' europeo si no se sabe bien lo que fue ser cristiano, ni lo que fue ser cristiano sin saber lo que fue ser estoico, y así sucesivamente. Y este sistematismo rerum gestarum reobra y se potencia en la historia como cognitio rerum gestarum» ${ }^{195}$.

Ante la historicidad humana, el Don Juan español es el hombre horrorizado por la temporalidad y la fugacidad de la vida y sus mejores ideales. Para algunos es sólo un ejemplo del ser frívolo, concupiscente e impío que sobrecogido por el castigo del absoluto se convierte a última hora. Su conversión es también propia de almas características y, en cierto modo, asustadas. Para Ortega, más allá de eso don Juan es el drama humano percibido, entre las carcajadas, con esenciales dolores. No es tampoco un fanfarrón empeñado en negar todo ideal y norma si no le destruye el mismo Dios omnipotente de un manotazo. Don Juan es el ideal del momento heroicamente negado: «Pero entonces don Juan no es un botarate, sino terrible símbolo de una simiente trágica que, más o menos incubada, llevamos dentro todos los hombres: la sospecha de que nuestros ideales son mancos e incompletos, frenesí de una hora embriagada que culmina en desesperación, embarque jovial que una vez y otra hacemos en naves empavesadas, las cuales siempre al cabo periclitan» ${ }^{196}$.

Don Juan no es por tanto un barriobajero sino un símbolo de un problema radical de la Edad Moderna. Es como el hombre que no cree en nada y por eso se lanza a la acción. Pero don Juan rehúye el amor casquivano y de ramera hasta que encuentra una mujer verdaderamente enamorada. No ver en don Juan un ser especial sería una mentalidad roma, propia del cura de pueblo que se inventa estúpido al maniqueo para refutarlo mejor, nos dice Ortega. Hay que intentar comprender a don Juan aunque nunca se consiguiera del todo. Dicho sea de paso, tampoco Ortega se considera capaz de dar lecciones a don

193. V1 39.

194. Ibid., 43.

195. Ibid.

196. Ibid., 124; TAO (1942); «Introducción a Don Juan», El Sol (6.1921). 
Juan. Y a Ortega se le ha calificado como filósofo mundano; «yo no me siento con denuedo bastante para enseñar a don Juan lo que es la mujer; antes bien, hombre de ninguna mundanidad y desprovisto de buenas fortunas, aspiro a aprenderlo de él, condensación ejemplar de la experiencia masculina» ${ }^{197}$.

Don Juan, como el corazón nacional español, es también puro contraste. Cervantes llamaba a don Quijote el Extremado. «Los españoles solemos ser así: o extremados, o nada. Por eso en esta leyenda hay escenas de mediodía y de media noche, virginidad y pecado, carne moza y masa cadáver, orgía y cementerio, beso y puñal. Al drama humano asisten cielo, infierno y purgatorio, que, como espectadores de una corrida de toros, no logran contenerse y acaban por tomar parte en la función» ${ }^{198}$. Don Juan es la historia en marcha y en huida. Ese tiempo del que decía Gracián que «sabe muchas cosas por lo viejo y lo experimentado» ${ }^{199}$. Es don Juan la Sevilla parladora, la España fugaz que vive y anda con un mínimo de aliento sin respiro ni argumento. Es toda Andalucía, en Sevilla, donde: «Las cosas tienen el mínimum de realidad necesario para expresarse y flamean parlantes como lenguas de fuego en un inacabable Pentecostés. Hasta el olivo, árbol tan serio y preocupado de su prosaica utilidad, no logra allí impedir que su tronco, al alzarse de la tierra y antes de llegar a la fronda, dé en el aire un gracioso quiebro. En suma, que al bajar del Guadarrama, Sevilla parece una inmensa arquitectura de reflejos y una 'integral gesticulación'... Colores, vivos colores de Carnaval, terciopelos rojos, verdes jubones, blancos de hábito monjil, como en Zurbarán; azules de Murillo, carmesíes de sangre. Y oímos un tropel de rumores, donde todo va confundido: risotadas con lamentos, trozos de canciones y tintineos de espadas, carracas de Viernes Santo, campanas de Resurrección. Esta leyenda (de Don Juan) es espiritista, se sube un poco a la cabeza» ${ }^{200}$.

Don Juan es el sevillano auténtico y máximo con un epicureísmo heroico y universal. A la vez todo ese paisaje nos invita al amor sin fin, a caminar con el sufrimiento humano de paso hacia la resurrección. «Late, pues, en cada localidad un posible destino humano, que parece en todo instante pugnar por realizarse y actúa como un imperativo atmosférico sobre la raza que lo habita. A su vez, cara forma típica de la vida humana proyecta ante sí el complemento de un paisaje afín» ${ }^{201}$. El capricho humano queda sustituido por el destino de la tierra: Así, en Toledo hay que entrar poco a poco como en Jericó, sus calles nos ponen en guardia, su sierra es como un paisaje tibetano. Allí hay que

197. VI 125.

198. Ibid., 126.

199. Ibid., 127.

200. Ibid.

201. Ibid., 129. 
vivir en un 'alerta eterno': «La ciudad sólo tiene escape hacia el firmamento. Cenobio y cuartel, la existencia aparece en ella como un servicio militar de tierra y cielo, que endurece los pechos contra el dardo y la tentación» ${ }^{202}$.

En Toledo se unen la espadaña del convento y el torreón. Almas de soldados con fantasmas trascendentes. El Entierro del conde de Orgaz del Greco refleja ese carácter. El guerrero va a la tumba con sus hierros acompañado por los grandes de la ciudad incluidos frailes y prestes: «Sobre la escena gravita la formidable alucinación de la fauna celestial. El Greco ha querido dar la impresión de uı corro sin que desaparezcan del primer término las tres figuras esenciales: el cadáver y los dos santos revestidos de suntuosos ornamentos. Grave, corpóreo, pesando sobre la tierra, este grupo atrae el tropel de cabezas que palpitan en torno como llamas lívidas o enjambres de falenas que vibran sobre las gemas de la capa pluvial. A ambos lados, unas figuras alargadas hacen un arrebatado aspaviento, y a la derecha, un clérigo con sobrepelliz parece ser el 'artista' del divino fraude. Tiene el ojo hacia lo alto, exultante, lleno de iluminación y todo él un gesto de artista a quien sale bien un número del programa. (Mientras hacemos estas observaciones, sumidos en la medialuz de la iglesia, el sacristán, contemporáneo nuestro, contrasta una peseta que le han dado contra los ladrillos y la pila del agua bendita)» ${ }^{203}$. Toledo huele a guerra y a visiones de almohades y templarios.

En este ámbiente don Juan es elegido para ser atacado y vilipendiado por los moralistas o poetas. En la época moderna no todos tienen magnanimidad para comprender, sin envidia ni mezquindad propias de almas encogidas, escolásticas, los valores trascendentes del don Juan más allá de su apariencia inmediata. Es lo típico de esa época llamada ya a terminar: «Y es preciso, ante todo, que rehusemos el crédito a su dogma principal, aquel pensamiento subversivo y nihilista que deslizaba en el oído de cada hombre buscando halagador a las almas plebeyas: 'Lo que tú ves eso es lo real'. No; nada de eso. Para percibir una realidad es necesario previamente convertirse en órgano adecuado para que ella penetre en nosotros» ${ }^{204}$.

La vida, en efecto, como decía Dilthey es una misteriosa trama de afán, destino y carácter. No sabemos por qué, en un determinado momento, surge una idea o se renueva una experiencia. Por ejemplo, san Agustín habla de la duda y la existencia. Pero sólo con Descartes aparece la cuestión con nueva claridad y dimensiones insospechadas. Hay una influencia general, de todo en todo, pero luego cada problema sufre sus propias peripecias. Se comienza a

202. Ibid., 131.

203. Ibid., 131-132.

204. Ibid., 133. 
partir de la historia concreta hasta que todo toma una dimensión trascendente. Así en la formación de la religión primero se dan ideas primitivas sobre realidades concretas divinizadas, después viene' el monoteísmo y por fin se crea un pensamiento filosófico con poca religiosidad. Eso ocurre en la humanidad en general. En Oriente se tiene un sentido providente y de vinculación directa con lo divino. Esto: «Se manifiesta en la remoción del centro de gravedad de la existencia a lo trascendente y en la consecuente transformación de la realidad en alegoría divina, en un simbolismo de lo suprasensible» ${ }^{205}$.

Después de constituirse las ciencias, surge la historia y la filosofía de la vida. Entonces la filosofía como metafísica y absolutismo del intelecto se vuelve imposible: «De aquí que la figura del mundo construida por el intelecto con un cariz de absoluto y de eternidad sea, en rigor, figura histórica, relativa a un tiempo. La metafísica no es, pues, la realidad del mundo, sino 'visión del mundo', espejamiento de lo real en el espejo viviente y, por ello, cambiante que es el hombre. En suma, metafísica es la ilusión óptica resultante de inadvertir el intelecto que no trabaja solo y por sí, sino a cuenta y con el material que es el hombre íntegro - con su sentir y su querer y su tradición intelectual, positiva o negativa» ${ }^{206}$.

Es necesario un tratamiento más equitativo de las distintas vigencias vitales de cada tiempo. A veces se dejan de lado las realidades deslucidas, sin darse cuenta, que suelen tener superior importancia. Es lo que ha ocurrido con pensadores como Plotino o escuelas consideradas secundarias en la historiografía filosófica. Es lo que pasaba con el estoicismo, el epicureísmo o el escepticismo. Y sin embargo: «Jamás filosofía alguna ha sustentado tan efectivamente un Imperio como sostuvo el estoicismo el colosal gobierno de los Antoninos. (Véase Rostovtzeff, Historia social y económica del Imperio Romano, 1, IV, Espasa-Calpe 1937). Pero además en el regazo de esas filosofías muere el mundo antiguo y nacen los pueblos nuevos de Occidente. Porque el cristianismo incipiente había sido penetrado hasta lo más profundo de su masa, aún informe, tierna y germinante, por la teología y la ética de los estoicos. Más aún: en el Renacimiento, tras un superficial rebrote de la influencia neoplatónica, son esas tres filosofías las que de verdad transmiten la savia antigua a los hombres novísimos que van a abrir las puertas de la Edad Moderna. Las tres filosofías, como tres hadas madrinas, se hallan en torno a la cuna del cartesianismo, y por tanto, de todo el racionalismo clásico europeo» ${ }^{207}$.

205. Ibid., 205; Guillermo Dilthey y la idea de vida, en Revista de Occidente 125-127 (1933); (1934).

206. VI 207.

207. Ibid., 380; Prólogos (1914-1943): «A 'Historia de la Filosofía' de Emile Bréhier», Buenos Aires (1942). 
A veces, temas un poco extraños ya a nuestra época pueden haber tenido influencia decisiva sobre concepciones fundamentales. Por ejemplo, el movimiento circular de los cielos se une, en un tiempo, a la concepción de Dios como acto puro. Aristóteles mismo concebía el pensar como movimiento. Eso es como ver la interioridad del ser que no es estático, ni quieto sino en incesante creación de sí mismo. El verbo 'ser' toma sentido activo, ejecutivo y de ejercicio: "A la concepción estática de los puros griegos este hombre nacido en el borde de la Hélade sustituye una concepción dinámica. Ya no cabe poner como ejemplo del ser una figura geométrica que es puro aspecto o espectáculo, sino que 'ser' va a significar el esforzado sostenerse de algo en la existencia.

Sobre la noción del ser estátịco triunfa la noción del ser enérgico» ${ }^{208}$.

Como se ha dicho, más arriba, la física actual no permite mantener el concepto de sustancia continua ni ninguno de los paradigmas, incluidos los metafísicos y religiosos, que en ella se sustentaban. Como dijo, en cierta ocasión, Einstein a Ortega: «La física es aquel modo de concebir los fenómenos en que evitamos el movimiento continuo» ${ }^{209}$. Eso quería decir que la materia continua ha terminado para siempre y por tanto también el paradigma que producía, a saber: la sustancia estática.

En la Edad Media cristianos y árabes, al fin y al cabo todos hombres de Dios, como dice Ortega, introdujeron el concepto de humanitas que intentaba traer a tierra las ciencias teológicas. Luego todo quedó en una mera dictadura de los gramáticos y de las palabras. Aunque Menéndez y Pelayo dijera que las humanidades eran la 'médula de león' de los saberes, muchos humanistas sólo trataban con el pasado y, con frecuencia, ni siquiera eran recomendables por su conducta. Para Ortega, en general, el Renacimiento no fue positivo ni en literatura, ni en política ni en religión: «A fines del siglo pasado y en el primer cuarto de éste fue 'opinión reinante' en Europa ostentar gran beatería al Renacimiento y al Humanismo que impidió ver bien lo que éstos habían sido. La batería es, por esencia, confusión... La filosofía del Renacimiento no es tal filosofía, sino un 'hacer que se hace' y un puro lío. Menéndez y Pelayo - que no solía tener razón - tiene un pedazo de ella cuando considera al Renacimiento como un movimiento subversivo, de sobra frívolo por cierto» ${ }^{210}$.

El Renacimiento es como el positivismo que es una filosofía sin filosofía. En Alemania se fue hacia el kantismo de nuevo, ya que la escolástica no se quería plantear los problemas filosóficos últimos y extremos. Como los escolásticos, los griegos padecieron radicalmente el error de creer que la idea, con

208. VI 415 nota 1.

209. Ibid., $416\left(^{*}\right)$.

210. VIII 352-353; IL (1947). 
ser clara, ya se impone y actúa. Fuera del cristianismo, en que el Logos se encarna, esto es una creencia mágica. La vida, la historia es, pues, variada, no es tan racional como se pretendía, está también el azar, el juego o la providencia que tanto se les parece: «Lo que yo quiero decir es lo siguiente: que el hombre es como un juguete en la mano de Dios, y que eso, poder ser juego, es precisamente y en verdad lo mejor en él» ${ }^{211}$. La vida es juego y cultura, eso es lo más serio que hay. El juego es esfuerzo y resistencia. Existir es resistir: «En el existir va incluido el resistir y, por tanto, el afirmarse el existente si nosotros pretendemos suprimirlo, anularlo o tomarlo como irreal. Por eso lo existente o surgente es realidad, ya que realidad es todo aquello con que, queramos o no, tenemos que contar, porque, queramos o no, está ahi, ex-siste, re-siste» ${ }^{212}$.

El hombre no existe rígido sino que vive y todo lo demás se afirma dentro del ámbito que les ofrece la vida. Esa vida humana, mi vida, es la realidad radical, raíz de todo lo demás y abierta a todo, la vida verdadera y genuina, «para que toda otra realidad en ella se manifieste y celebre su Pentecostés. Dios mismo, para sernos Dios, tiene que arreglárselas para denunciarnos su existencia y por eso fulmina en el Sinaí, se pone a arder en la retama al borde del camino y azota a los cambistas en el atrio del templo y navega sobre Gólgotas de tres palos como las fragatas» ${ }^{213}$.

Lo divino se temporaliza en la historia. esto nos muestra el destino transrelativo 'y como eterno del hombre'. Para Descartes y el siglo XVIII la historia es la narración de los errores humanos, de la voluntad pecadora. En cambio el positivismo y el historicismo del siglo XIX no creen nada, «se desentienden de todo valor eterno para salvar el valor relativo de la época. Es inútil que intentemos violentar nuestra sensibilidad actual, que se resiste a prescindir de ambas dimensiones: la temporal y la eterna. Unir ambas tiene que ser la gran tarea filosófica de la actual generación, para la cual yo he procurado iniciar un método que los alemanes propensos a la elaboración de etiquetas me han bautizado con el nombre de 'perspectivismo'» ${ }^{214}$.

La vida humana se contamina de trasmundo y viceversa. Mientras el cristianismo es una forma definida de vida y una teología, la religión griega es una mezcla de todo: Está instrumentada por el Estado, se mezcla con lo festival del pueblo. El teatro y el templo se confunden y viven anejos uno al otro. El mundo ordinario transformado en extraordinario, no habitual, excepcional postula lo divino. Culto, arte, religión y orgía se unen. La embriaguez y el éx-

211. VII 347; QF (1929).

212. VII 101; HG (1949-1950).

213. VII 101.

214. Ibid., 285-286; QF (1929). 
tasis se mezclan. La fiesta se alcoholiza y coloca en otro mundo, lleva a la ultravida, superior y sublime. La religión dionisíaca es un caso ejemplar: Como hay una imitación de Cristo hay una imitación de Diónisos. Ésta lleva a perder la cabeza, a la experiencia frenética y a la manía divina. Las religiones antiguas no son fe como el cristianismo sino culto: «No se trata en ellas de recogerse dentro de sí y allí en la soledad de sí mismo, en la 'soledad sonora' del alma (san Juan de la Cruz) encontrar a Dios que mana en nosotros como un hontanar desapercibido, sino que se trata, inversamente, de 'ponerse fuera de sí, de dejarse absorber por una extrarrealidad, por otro mundo mejor que de súbito, en el estado excepcional y visionario, se hace presente, logra su epifanía» ${ }^{215}$.

En Grecia hay divinidades telúricas, inferiores, y una camada aristocrática. Diónisos es de una popularidad intermedia entre ambos. «Diónisos es, sin duda, el dios más dios que tuvieron los griegos» ${ }^{216}$. Diónisos es abandonarse a una fe más allá de la razón. Como todo dios es azorante. A la vez bueno y malo, delicioso y terrible. Ante él hay que abandonarse, dejarse de sí mismo y de ser policía de sí mismo y caer en la divina 'manía'. Diónisos es la visión de un ultramundo que es la verdad de este mundo. Es el dios vino, lo divino como embriaguez. Culto y fiesta. Nuestras fiestas desdiosadas, descarnadas de lo religioso, son fiestas sin emoción, profanas y profanadas. «Nietzsche decía con verdad rebosante que 'toda fiesta es paganismo'. La religión cristiana, al descalificar la vida humana como consecuencia de haber descubierto un Dios más auténticamente Dios que los paganos, esto es, más radicalmente trascendente, mató para siempre el sentido festival de la vida» ${ }^{217}$. Hasta hoy, todavía, no se ha podido resolver de forma satisfactoria la relación entre religión popular y autenticidad religiosa. Lo divino sigue siendo un misterio tremendo y a la vez fascinante. Presencia de otro mundo y verdad de éste, revelación y fantasmagoría en las que se unen muerte y vida, naufragio y salvación. La embriaguez sigue con un carácter de quid divinum y viceversa. La devoción y la diversión se entremezclan, lo deportivo y festival de la vida se unen con el trasmundo y la teoría. El hombre quiere ser lo que no es, lo absoluto, y espera que éste omnipotente le haga a su vez todopoderoso.

El tiempo continúa su tarea destructura y creadora: «El tiempo es el Universo como río» ${ }^{218}$. El tiempo es nuestra vida y hay que aprovecharla. A un ser que fuera inmortal y temporal no le importaría nada el tiempo, puede per-

215. VII 481; «Idea de teatro». Anejo I. Máscaras (1946).

216. VII 482.

217. Ibid., 487.

218. Ibid., 497. Anejo II. O Seculo (4.5.1946). 
derlo tranquilamente, nosotros no. Nuestra vida es prisa. No tenemos, por delante, una eternidad, ni nuestra vida es una vida interminable que poseamos totalmente. No tenemos garantía. Se procura despistar la muerte. En Colombia se dice, cuando muere alguien: ayer fulano 'se quedó indiferente'. Cada día es único para nosotros, no es posible tener mucho más de noventa o cien años, por eso, el hombre necesita estar en la verdad imperiosamente y acertar ${ }^{219}$. Por eso también, la religión auténtica es lo contrario de la negligencia, descuido e insensibilidad. En un primer momento el hombre es optimista. El mundo es bueno, da gusto estar en él. Pero luego se ve que hay facilidades pero también dificultades. En aquél primer momento las creencias también son muy seguras y evidentes, luego flaquean y se vuelven difíciles. La fe parece, primero, simple cuestión de un entendimiento limpio. Así parece entenderlo santo Tomás. Luego dice que es un acto de adhesión tanto como de visión. Da la impresión que un problema del entendimiento pasa a ser más bien un asunto de la voluntad. El entendimiento queda como cautivo por la fe. Ésta es como un arrebato y como un éxtasis. Algo parecido a la prolepsis estoica. Entonces ya la creencia es como opuesta a la idea y a la intelectualidad. "Véase cómo, a su hora, todas las zuritas entran juntas en el palomar. Considero esta noción de la 'creencia' de suma eficacia precisamente en teología católica» ${ }^{220}$.

Ortega tiene la impresión de que el creyente que estaba seguro va cayendo en la duda por envidiar la filosofía y el racionalismo. De modo que al fin se recurre a la urgencia de creer todos lo mismo para evitar dudas innecesarias y se hace la fe incuestionada por el contorno social. san Vicente de Lerins en su Commonitorium (del año 434) dice que " «magnopere curandum est, ut id teneatur quod semper, quod ubique, quod ab omnibus creditum est'» ${ }^{221}$.

Tiempo habrá de ver cómo Ortega analiza profundamente el binomio duda y fe, profundamente unidos en el creyente crítico.

\subsubsection{Como se entiende a Dios se mira al mundo, y viceversa}

El optimismo de Leibniz dice así: «'De la Perfección Suprema de Dios se sigue que al producir el Universo ha escogido el mejor Plan posible, en el cual se dé la mayor variedad con el mejor orden; en que el terreno, el lugar, el tiempo queden mejor arreglados; en que se produzca el mayor efecto por las vías más sencillas; en que haya el máximum de potencia, de conocimiento, de dicha y de bondad que el Universo puede admitir. Porque todos los posibles,

\footnotetext{
219. VII 500.

220. VIII 255; IL (1947).

221. VIII 255.
} 
pretendiendo la existencia en el entendimiento de Dios proporcionalmente a sus perfecciones, dan como resultados de todas estas pretensiones el Mundo Actual más perfecto posible. $\mathrm{Y}$ sin esto no sería posible dar la razón de por qué las cosas son como son y no otra manera'» (Philosophische Schriften, VI, 603) ${ }^{222}$.

Según Ortega, quien hoy lea esto, sin conocer bien el pensamiento de Leibniz, no entenderá el problema realmente. Creerá que se trata de teología o de mística. «Y, sin embargo, todas sus expresiones designan conceptos de rigurosa racionalidad que, articulados con la mayor precisión teórica constituyen un admirable edificio doctrinal» ${ }^{223}$. Leibniz es el primero que se ha preguntado ¿por qué existe algo y no más bien nada? Estudia el problema de los posibles y da cuenta de que si hay posibles, hay creación y libertad. En otro caso Dios estaría necesitado absolutamente de producir todos los posibles o nada. Ya que todos los posibles, pueden llegar a ser ha de haber una elección. El paso de la posibilidad a la existencia es absoluto, pero de hecho se ha dado. Este mundo existe. Y «Aquel poder absoluto el cual, dice Leibniz, uno vocabulo solet appellari Deus, tuvo que elegir entre los posibles» ${ }^{224}$.

Según Leibniz Dios no crea por una necesidad metafísica, sino por una necesidad moral: Se ha de elegir lo mejor. «Tan pronto como Dios ha resuelto crear alguna cosa, tiene lugar un combate entre todos los posibles, ya que todos pretenden a la existencia. Aquellos que juntos producen más realidad, más perfección, más inteligibilidad, triunfan» ${ }^{225}$. El optimismo de Leibniz no es de humor, es el optimismo del ser. Éste y lo bueno son recíprocos y la naturaleza tienden a lo mejor, entre lo posible, también según Aristóteles.

Ahora bien, esto es lo que dice la metafísica. Después viene la realidad de la vida: Atropellos de inocentes, muertes de justos y burlas de honrados, ladrones reverenciados, engaños de inexpertos, llamadas y oraciones a los santos para que libren nuestras batallas más sucias limpiamente, eclesiásticos ricos y malos, curas y damas mezclados, una nobleza pedigüeña, difuntos y conversiones, la ciencia y el demonio, bandoleros y santa hermandad ${ }^{226}$, bofetadas entre frailes, el rey que caza una zorra, hechizos, amoríos, fuegos y Estado. En fin: «Todo lo que en España se ve parece encanto de canto. Remédiele quien puede que sólo es.Dios, que guarde a VM» ${ }^{227}$.

222. Ibid., 328-329.

223. Ibid., 329.

224. Ibid., 339.

225. Ibid.

226. Ibid., 536; «Avisos de Pellicer. (Semanario erudito), en De la España alucinante y alucinada en tiempo de Velázquez (1959).

227. VIII 538; «Avisos de don Jerónimo de Barrionuevo» (1654-1658), en De la España alucinante y alucinada en tiempo de Velázquez (1959). 
Como es de ver, lo divino no facilita, sencillamente, las cosas. «De suerte que pertenece a la idea misma de divinidad, del Dios, el carácter dual del ser hostil y favorable, adverso y proverso. Con su enérgico y torsionado decir, san Agustín clama ante Dios al sentirse en su presencia: Et inhorresco et inardesco. 'Me espantas y me exaltas; me horrorizas y me hechizas»' ${ }^{228}$.

Tampoco el hombre se queda atrás. No tiene un ser fijo, es enorme en posibilidades. Ha usado las torres de petróleo para dar culto a Zoroastro. El único animal capaz de hacerse unos zapatos con el pellejo del vecino, dijo Spinoza. «Nadie puede decir de qué el hombre no es capaz en su tiempo y ocasión» ${ }^{229}$. Ciertamente, también para lo positivo. El mundo es para el hombre un camino de rosas y espinas. A Dios nada se le opone, al hombre sí: «Dios no tiene un mundo. El que crea lo crea para el hombre y es el mundo del hombre, no el mundo de Dios. Por eso Dios no tiene fronteras, límites, es i-limitado, infinito. Para Dios vivir es flotar en sí mismo, sin nada ni nadie ante Él ni contra Él. De aquí el más terrible y el más mayestático atributo de Dios: su capacidad para ser, para existir en la más absoluta soledad. Que el frío de esta tremenda, trascendente soledad no congela a Dios mide el poder de ignición, de fuego que en Él reside.

De aquí el profundo sentido del misterio de la Encarnación, en que Dios por un acto determinado, concreto, de su voluntad — permítaseme decir que divinamente paradójico - resuelve humanizarse, esto es, hacer y padecer la experiencia de vivir en un mundo, de dejar de estar solo y acompañar al hombre. Es uno de los lados del cur Deus homo, de por qué Dios se hace hombre» ${ }^{230}$. Ahora ya estamos iguales. También Dios ha salido de su paraíso y ha venido a este mundo difícil. Ortega propone a los teólogos que le escuchan la investigación sobre el estado primitivo del hombre y su felicidad ${ }^{231}$. Aquí también podría decirse, al Dios en carne humana, como el baturro del cuento «disculpa al nuevo Cristo llevado a su pueblo, de que 'no milagree porque aún es cachorro'» ${ }^{232}$. El mundo le va a poner muchas dificultades al mismo Dios en persona. El desconcierto de los creyentes no es pues nada de extrañar. Menos, el de los no creyentes.

228. IX 125-126, IHU (1948-1949).

229. IX 200.

230. Ibid., 209.

231. Ibid., 210.

232. Ibid., VI 510; Prólogos (1914-1943): «A ‘Aventuras del Capitán Alonso Contreras'». Publicado con la firma 'Los Editores' (3.1943). 


\subsubsection{Formas de ser cristiano}

La situación anteriormente descrita obliga a establecer distintos tipos de pactos y relaciones entre la fe cristiana y el mundo. El creyente es un hombre, por tanto vive su creencia desde una circunstancia exterior muy variable. Como hay distintas épocas y distintas concepciones del hombre hay también diversas formas de fe.

Los cristianos han mirado siempre hacia el mundo sea para integrarlo sea para rehuirlo. Algunos recogen gran parte de los valores vigentes en el paganismo, otros se aproximan a las distintas corrientes filosóficas para dar forma actual a su fe. San Agustín es un caso muy conocido de asimilación de concepciones vitales griegas y romanas que van a manifestar nuevos horizontes al cristianismo. No se puede expresar la fe de cualquier manera. Hay que ponerla al alcance y hacerla inteligible y experimentable a las personas que siempre viven en un tiempo, en un lugar y en una mentalidad determinada. Ortega piensa que san Agustín da mucha importancia a las ideas en el cristianismo. Eso manifiesta su capacidad de descubrir caminos de entrada a la fe para los extraños a ella. Esto era necesario en el norte de África donde convive la cultura indígena con el proceso de romanización. También hablamos hoy de cristianismo existencialista, cristianismo ecologista o cristianismo marxista. Independientemente de los acuerdos y desacuerdos de cada uno, con determinadas formulaciones, es evidente que no se explica y no se presenta el cristianismo del mismo modo a quienes están preocupados por la justicia, que a los que preocupa la salvaguarda del mundo natural o a aquellos que, sobre todo, creen en la libertad personal del hombre y su autenticidad. Todo esto crea de paso, problemas de identidad y de fe.

Las posibles presentaciones del cristianismo son, por consiguiente, muy distintas. $\mathrm{Y}$ esto no es algo que ocurre solamente a finales del siglo veinte. «Aunque sea el cristianismo el factor que gozó de mayor continuidad desde el fin del Imperio romano hasta los siglos góticos, su transformación en cuanto viviente realidad histórica había sido enorme. Como todos los demás componentes de la cultura grecorromana había sufrido una involución tan acusada que si no nos quedamos detenidos ante la identidad externa de ciertas fórmulas, apenas reconoceremos en el cristianismo gótico la misma religión que en el antiguo»" ${ }^{233}$. Ahora bien, nadie utiliza las teorías antropológicas o filosóficas en las que presenta el cristianismo del mismo modo que lo hizo el autor original. A no ser que creamos que hay una significación o concepción ómnibus de cada filosofía que vale para todo mundo. No es lo mismo lo que se llama pla-

233. IX 334-335; «Vistas sobre el hombre gótico» (sin fecha). 
tonismo en el cristianismo de san Agustín y lo que se llama platonismo en Plotino o en Platón, ni siquiera es lo mismo el aristotelismo cristiano de santo Tomás que el de Aristóteles. Ortega lo sabe perfectamente: «No se puede entender con alguna proximidad a santo Tomás de Aquino si se interpretan sus expresiones aristotélicas con la misma significación que tenían para Aristóteles. Verdad es que tampoco solemos entenderlas en el sentido estricto que para este temían, sino que nos contentamos con una comprensión esquemática de ellas, que por lo mismo, proporciona una significación ómnibus, valedera para cualquier tiempo y cualquier hombre precisamente porque no vale en rigor para ninguno» ${ }^{234}$.

El mundo medieval funcionaba como un bloque compacto e inatacable. La Iglesia había conseguido consolidar en las almas la fe con una seguridad absoluta. El cristiano no se hacía distinciones entre la fe y sus ideas. Pensar en un medieval para el que su fe no era razonable y lógica es como pensar en un hombre que decide salir a la calle y de repente se encuentra «con que no hay calle, sino un abismo insondable» ${ }^{235}$. Las creencias vigentes no aparecen como creencias sino que las vemos como la realidad misma. El medieval no distingue más entre mundo de la fe y mundo real. Tal distinción aparece mucho más tarde. Lo que no quiere decir que el medieval no distinga entre este mundo y el mundo futuro: «La Edad Media, la Edad Media europea, se identifica con el cristianismo: éste es la vida interpretada como vía, como viaje a la ultravida que es donde se reposa y se vive en plenitud. En realidad, pues, el cristiano -en la medida en que es vigorosa y eficaz su fe- está fuera de este mundo, anticipando el otro. Este mundo, el intramundo es fantasma y alucinación para el cristiano; el otro mundo, el trasmundo o ultramundo, es el auténtico» ${ }^{236}$.

El Renacimiento no consigue la síntesis entre mundo divino y mundo humano. Esa tarea la realizan Descartes y Leibniz, según Ortega. Entre tanto hay una crisis de creencias. Hacia 1300 la fe es tranquila, hacia 1500 hay dudas, pero desde 1600 la fe en la razón comienza a sustituir la «fe en Dios» ${ }^{237}$. Son siglos de azoramiento, de choque entre sobrenaturalismo y naturalismo. Es la salida de Egipto y de la casa cristiana. Hoy ocurre igual otra vez ${ }^{238}$. La vida deja de tener un sentido teocéntrico como en tiempo de Dante y se comienza a vivir de cara al mundo y con el hombre como centro. Antes no era importante trabajar sino orar. La vida ha girado 180 grados, la vida se mira

234. IX 337.

235. Ibid.

236. Ibid., 526; «Juan Vives y su mundo» (12.11.1940).

237. IX 527.

238. Ibid., 528. 
desde Dios pero hacia el mundo: «desde Dios se mira no a Dios, sino al mundo, y se atiende a lo terreno. El protestantismo acabará en media Europa con la vida monacal. Lutero resume su moral religiosa diciendo: 'Hay que seguir la obra de Dios en el mundo', en este mundo. ¿Creen que es casual que Ignacio de Loyola funde, precisamente en este tiempo y frente a Lutero, un orden, la primera que en absoluto no es orden monacal, cuya finalidad no es el retiro ni la oración, sino la pelea en medio de este mundo, la conquista de este mundo para Dios y a la que por eso da un nombre militar: 'Compañía de Jesús', es decir, una especie de Tercio castellano a lo divino? He ahí en lo que habían coincidido, sin advertirlo, Lutero y san Ignacio»" ${ }^{239}$.

Ahora la fe incide muy diferentemente sobre el mundo, el hombre y su trabajo. El hombre pasa a ser el centro del mundo mientras que, en el mundo antiguo, la afirmación del hombre y el pecado viene a ser lo mismo, es como enfrentarse a Dios: «Es decir, que afirmarse el hombre a sí mismo, que todo entusiasmo hacia algo humano y de este mundo es ya pecado; es lo que san Agustín llamaba 'concupiscencia'. El hombre medieval tiene de la vida una concepción teocéntrica, como la Antigua Edad tenía una concepción cosmocéntrica, y como la Edad Moderna que en este preciso punto empieza ya formalmente con Vives, tendrá una concepción antropocéntrica» ${ }^{240}$. En el hombre moderno todo es intramundo, se glorifica el trabajo y la atención al hombre en vez de ir a ocuparse constantemente de Dios: «Dios deja de estar en el primer plano del paisaje y empieza a vérsele solo, allá lejos, como el remoto altanero picacho de una serranía, gélido y blanco de nieve, cuyo papel es precisamente cerrar el paisaje, ser su fondo o último plano, pero no intervenir en él» ${ }^{241}$.

Comienza la importancia de la riqueza, del arte intrahumano, del entusiasmo por lo humano; se seculariza la religión y su forma eclesiástica: «Hasta entonces, la relación del hombre con Dios se realiza a través del ritualismo clerical -dirigido por la jerarquía de los sacerdotes y obispos, cardenales, papa, por medio de los conceptos difíciles creados por la sutileza oficial de los teólogos, que eran clérigos- y se manifiesta en las ceremonias y reglas catedralicias y conventuales» ${ }^{242}$. Ortega advierte al paso, que se trata de un diagnóstico y no de una crítica como si se tratara de exponer un pasaje de la filosofía de Descartes, con quien se inicia la época moderna. Lo cierto es que se da una democratización de la religión: «Este estado de espíritu hizo que, en torno a

239. Ibid., 529.

240. Ibid., 528. Vives es el primer antropólogo que ha existido. Brunswick toma a Vives como tema de su tesis académica y le llama 'philosopho praesertim Anthropologo': IX 529-529.

241. Ibid., 530.

242. Ibid. 
1370, el holandés Gerardo de Groote fundase - síntoma que parece casi inapreciable, pero que encierra en sí, como en una microscópica semilla, toda la Edad Moderna-, fundase un convento de laicos para adorar a Dios, al Dios cristiano, al Dios de siempre, pero sin intromisión clerical. Se llamaron los 'Hermanos de la vida común'. Su religión consistía en la deliberada simplificación de la tradicional, en una conducta dulce, en hablar de Jesús y en enternecerse. El abad de su convento más importante, el de Windesheim, que va a tener tanta influencia posterior, se hizo llamar 'Juan No sé'» ${ }^{243}$.

Se trata de una nueva sensibilidad, una fuerte sencillez, «frente a la fiera religión, a la religión magnífica y prepotente de los frailes y obispos medievales» ${ }^{244}$ : quizás demasiado lacrimógena y en cierto sentido decadente que, como los revolucionarios del tiempo de Rousseau, a la vez que preparaban la revolución se derretían en lágrimas por cualquier cosa. Un poco romántico todo. Pero esa religión con el nombre de Devotio moderna se extendió por toda Europa. Su programa fue: «La Imitación de Cristo que, lejos de ser como su título suena, un arte de despreciar radicalmente al mundo, De contemptu mundi, es un comienzo de afirmación intramundana hecho desde la religión misma. En el convento inicial de la Devotio moderna, en Deventer, se educó Desiderio Erasmo, del cual va a manar toda la reforma protestante» ${ }^{245}$.

Esta religión democratizada, menos jerárquica y clerical, menos teológica, crea una piedad sin complicaciones para todos los hombres, incluso los más pobres. Todo había comenzado hace tiempo con el pobre Francisco de Asís: "Ya siglo y medio antes, como precursor, había caminado por el mundo la incandescencia estremecida del 'pobrecito de Asís'. Ahora se 'vulgariza' resueltamente la religión, haciéndose más íntima y directa entre Dios y el hombre cualquiera, el iletrado; 'lo que el cardenal Cusano llama el 'idiota'; es decir, el privado, el que no es clérigo, ni teólogo, ni tiene puesto en la jerarquía eclesiástica. Esta religión vulgarizada se despreocupa de cuestiones dogmáticas y teologales. Para ella Cristo hombre es todo, Jesús, el Dios intramundano, no el Deus absconditus, remoto e inasequible. Se prescinde de los clérigos y frailes que, de pronto, después de haberlo sido todo, empiezan - no se sabe por qué- a ser impopulares» ${ }^{246}$.

El español Luis Vives es un paradigma de esa situación. Vives es cristiano sin duda, como todo su tiempo. Los que en esa época se declaraban ateos solían ser personalidades botarates de las cuales se puede decir que dárselas de

243. Ibid., 531.

244. Ibid.

245. Ibid.

246. Ibid. 
algo es índice cierto de no serlo. Pero lo importante es saber cómo era cristiano Vives; ya no era su fe en el Dios fiero del Antiguo Testamento sino del Nuevo: «No es el Dios del Sinaí, el Dios trascendente, el Dios del cristianismo oriental y agustiniano, que es, ante todo, el ultra ser misterioso de la Trinidad, el Dios que interesa, que adora el siglo XV, sino el Dios que baja al mundo. Por tanto, si se me entiende bien, más que Dios, Jesús, Cristo» ${ }^{247}$. Es la época de la obra de Tomás de Kempis.

Pero junto a esa fe firme del estrato más profundo de su vida, en la que actúa la plena fe en Dios sin equívoco, hay también en Vives otra esencia menos compacta e imprecisa pero también muy viva: «la fe en la concepción del mundo que tuvieron los clásicos grecorromanos, por tanto, en el paganismo. No se olvide que Vives nace en las generaciones humanistas, y ese mundo pagano es, en verdad, un mundo sin dioses auténticos, sin orbe trascendente, es el mundo natural sin nada de sobrenatural» ${ }^{248}$.

Vives fue el primer intelectual serio y sereno. Bacon es ya otra cosa. Münzer era un insensato revolucionario. Paracelso un frenético de la especulación intelectual. Los demás son la inestabilidad misma. Savonarola es su revés, parece un santo, luego pasa a demogogo y luego da la impresión de un 'trágico histrión'. El escolasticismo está exhausto y se baila la danza de la muerte. Erasmo cambia la jovialidad por la amargura. Vives se queda en la ciencia, la técnica, la antropología pero no es un gran personaje en teología. Tampoco en él las creencias aparecen ya como la realidad misma. Es un intelectual que tarda en llegar a sí mismo: «Probablemnte, como él y los humanistas de su tiempo seguían creyendo en Dios, pero con fe inerte y lo tenían ya a su espalda, muchos hombres hoy siguen creyendo en la 'cultura', pero como en algo que está tras ellos, no delante» ${ }^{249}$.

En tiempo de Vives las creencias son materia confusa. «Vives es cristiano, pero con esta palabra se ha dicho muy poco. ¡Ha habido tantas maneras profundamente distintas de ser cristiano, es decir, de creer en el Dios de la Biblia y del Dogma! En el café o en el diario se presumirá de haber dicho algo muy estricto cuando se ha dicho de alguien que es cristiano; pero en verdad, no se ha hecho más que usar una palabra equívoca que significa innúmeras cosas.

Vives es cristiano, pero era erasmista. ¿Es cristiano un erasmista? ¿Un erasmista es cristiano? Desde luego no lo es como lo era santo Tomás de Aquino, ni como lo fue san Agustín, ni siquiera como lo va a ser Ignacio de Loyola» ${ }^{250}$. Vives invita a cenar a Ignacio de Loyola y le impresionó. Vives era un

\footnotetext{
247. Ibid., 525.

248. Ibid., 526 .

249. Ibid., 538.

250. Ibid., 523-524.
} 
cristiano de tipo especial, creía en Dios que vino al mundo y más que en Dios, en Cristo. Vives alcanza a Dios, como Goethe, porque sabe concentrarse en la finitud, en la vida concreta, en el intramundo y no en el ultramundo. Vives comunica a Erasmo que los tiempos son difíciles. Como escribe Miguel de la Pinta Llorente: «Quizás, conocida la naturaleza intelectual humana, un profundo sentido cartesiano pudo en algún momento impulsarle al crisol de la duda en medio de las agitaciones de su tiempo, pero estuvo garantizado por la doble fidelidad al acontecimiento espiritual y a la Institución divina. Ni la bazofia pseudoescolástica, ni la terrible y espantosa vacuidad y decadencia de los monjes que le rodeaban, le hicieron perder el buen sentido y la 'mensura'. Vives pertenecía al Humanismo integral y armónico. En Vives el Humanismo no era el engreimiento del hombre. Diríamos que era un varón extraordinario que, como quería Goethe, llega al infinito porque sabe concentrarse humildemente y amorosamente en su propia finitud. Ésta es la lección ejemplar de algunos de sus Tratados, escritos entre el confusionismo y las luchas sangrientas, en busca de la concordia y de la civilidad, de la tolerancia y de la piedad cristiana. Vives no denostó al parecer, a su patria. Así considerado, es para nosotros un hombre que existió plenamente» ${ }^{251}$. ¿Quería ser Ortega como Vives? He aquí una pregunta de difícil contestación absoluta. Pero digamos que bien pudiera ser así.

\subsubsection{Dios y el hombre in-sustancial}

El hombre puede ser un asno pero no el de Buridán. No es un mero elector sino también creador de su vida y de su historia: «Está siempre en viaje, in via, decían los teólogos medievales, sin darse bien cuenta de lo que decían» ${ }^{252}$. El occidental actual es así porque antes ha sido positivista, racionalista, demócrata y absolutista, cristiano, como Francisco de Asís, y otras muchas cosas más. El hombre es heredero por naturaleza. El siglo XVIII que es siervo de la escolástica, sin darse cuenta, creía en el naturalismo y por tanto en que: «Hay una religión natural —es decir, racional, idéntica a sí misma bajo todas sus deformaciones históricas. Hay un derecho natural y un arte esencial y una ciencia única e invariable» ${ }^{253}$.

Ahora bien, sobre el hombre real no es posible decir cosas generales, igual que dice el bromista: 'generalmente los generales no tienen ideas genera-

251. Pinta Llorente, M. de la, Procesos Inquisitoriales contra la familia de Juan Luis Vives, Instituto Arias Montano, Madrid 1964, 31-32.

252. IX 647; «Pasado y porvenir para el hombre actual». Rencontres internationales de Genève 1951. PPHA (1951-1954).

253. IX 648. 
les' sino que sólo tienen creencias. Cada uno está informado por la colectividad en que nació. Hay que recurrir siempre a la biografía que nos ofrece conocimientos concretos; no basta para Ortega decir que el individuo es inefable si bien reconoce que el «conocimiento histórico es, en verad, el cuento de nunca acabar» ${ }^{254}$.

Hoy sabemos que no hay cosas, no hay materia, no hay espíritu. Tampoco la ciencia puede darnos una alternativa a esta situación. Hay que dejar de ser nuevos ricos de la ciencia: «La ciencia tiene una misión espléndida: hacer cómoda la vida de los hombres, adaptar el mundo al delirio que es el hombre. Pero la misión de la ciencia no es ser nuestra intérprete ante la auténtica realidad» ${ }^{255}$. De mismo modo que no es posible ya creer por más tiempo en los derechos políticos 'por la gracia de Dios ${ }^{256}$; tampoco se puede identificar a Dios con el ente de los griegos que era algo inaudito y no era para el hombre sino para sí y en sí: «A la fuerza este monstruo hueco, tuvo, desde luego, que producir en el alma griega repercusiones de emoción religiosa. Era un nuevo Dios que se elevaba sobre el horizonte mental del hombre griego, pero un Dios de condición opuesta a todos los anteriores - un Dios hecho de indiferencia hacia el Hombre, aún más, de negación del hombre» ${ }^{257}$. El ente era un predicado sin sujeto, sin rostro, como 'nada' es un sujeto sin predicado. Los hombres necesitan el auténtico ser.

Aristóteles se pregunta por la sustancia. No por el ente sino por el ser. Y encuentra que tiene que existir «solo - de - los demás, suelto de los demás, absoluto» ${ }^{258}$. Entes y sustancias son los animales, el hombre, los astros y planetas, $\mathrm{y}$ «en un sentido excepcional superlativo, mas por lo mismo distante, Dios. Dejemos en un respetuoso aparte a la divinidad y preguntémonos: ¿Cómo llamamos hoy, en el cotidiano hablar, con nombre general, a todas esas demás sustancias? Les llamamos 'cosas', usando la significación más fuerte de esta palabra» ${ }^{259}$. Pero en algunas culturas no hay cosas. La traducción tradicional de ousía por sustancia «es inadecuada, porque destaca solo una de sus funciones - la sub-sistencia - y deja fuera las demás. Debíamos decir ousía (tipografía original griega) = 'una Realidad' o 'Realidad singular'» ${ }^{260}$. Ortega no está de acuerdo con Heidegger en que «el Hombre es pregunta por el ser» ${ }^{261}$. Porque el hombre no es. Ortega ha visto «la pura historicidad del

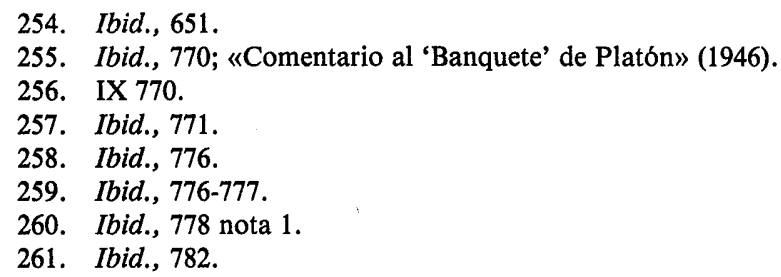


concepto 'ser' y con ello, in nuce, la radical historicidad de todo lo humano» ${ }^{262}$. Y por tanto hay que preguntarse qué cosa es una cosa. Para Ortega: «La circunstancia o mundo consiste en una perspectiva viviente o real; quiero ciecir, que hay en ellos siempre un primer término - lo que en cada instante me ocupa- y un fondo» ${ }^{263}$.

Al principio parecía que las cosas eran evidentes, claras, definidas y definitivas. Por ejemplo, la realidad del color depende de la cosa: «La cosa es antes que su color: está detrás o debajo de su color, es substancia de ella; en suma: en principio» ${ }^{264}$. Más tarde las cosas, se nos aparecen, como los impuestos en Roma que, según cierto manual de Derecho, comenzaron por no existir: «Pues bien; esta realidad - que parecía tan granada- del caballo y del hombre, de las cosas y de su conjunto o mundo, resulta que es una realidad dudosa, una realidad sospechosa. Por tanto, no puede pretender ocupar el rango de realidad primordial. En cambio, es incuestionable que veo el caballo, que veo el hombre» ${ }^{265}$. Para Descartes el mundo, las cosas, son dudosas, pero no mi dudar de ellas, ni mi duda, ni mi razonar, ni mis pensamientos, ni mi yo que son ellos. Ahora el mundo como independiente es una figuración. Las cosas han perdido su primera consistencia entitativa. Ortega no cree a Descartes un puro error, su admiración por él era indecible: «Me parece que es la cabeza más clara, acerada y buida que ha habido en Occidente. Pero tengo que ser fiel a mi mensaje. $Y$ tengo un mensaje que es, por lo pronto, agresivo contra él; si bien, al cabo, redundará en su homenaje» ${ }^{266}$.

Descartes no puede refutar el caballo que veo, no duda de todo. No se ha liberado de la ontología griega y escolástica que cree en la sustancia independiente, separada totalmente: «Descartes conservaba una noción de ser, de realidad, que había aprendido en el escolasticismo aristotélico. Esa noción que, como hemos visto, consiste en no considerar como real sino lo que es en absoluto independiente de mí. Y de eso claro está que se puede dudar...» ${ }^{267}$. En tal caso el mundo se va por un lado y el hombre por el otro, aquél queda abolido y éste se queda solo con sus pensamientos. Es el idealismo y el solipsismo.

Ante esta situación el realismo pretende afirmarse por medio de la cosificación. Así hace del cuerpo humano una cosa, del alma otra cosa gemela. Y Ortega sentencia: «En nuestra perspectiva, el famoso espiritualismo aristotéli-

262. Ibid.

263. Ibid., 784 .

264. XII 173; SRH. La razón histórica, Buenos Aires (1940).

265. XII 174-175.

266. Ibid., 176.

267. Ibid., 177. 
co se nos aparece como un resto de materialismo» ${ }^{268}$. Frente a esta problemática, según Ortega, ni siquiera Max Scheler que ha sido el gran redescubridor del tema de la persona, ha dado su verdadera talla. La ontología tradicional describe cosas que son. El hombre es algo distinto: «Es la existencia de un inexistencia... Y como el hombre es, ante todo, futurición; es, ante todo, un emjambre de esperanzas y temores» ${ }^{269}$.

Ortega, para la realidad esencial, en vez de decir que es prefiere decir consiste; lo que tiene verdadero ser, y es verdadero ser no tiene una existencia estática y natural, si bien, de algún modo ha de presentarse en ésta. Entonces aparecerá como no ser, ausente, de este mundo de las cosas aunque trasparentándose por ellas, viviendo en ellas y a cuenta de ellas: «Para lo que ahora interesa no hay más que esas dos formas de existencia: la existencia eterna que tiene el Dios - tomado este concepto en su significado puramente filosóficoo la existencia instantánea. Algo existe eternamente y es divino - o existe en el instante, por tanto, es ahora y sólo ahora»... «El ya no ser y el aún no ser son ambos no ser y viven a cuenta de lo que es ahora» ${ }^{270}$. Como en la temporalidad, lo que es ya no es y lo que aún no es tiene ser.

Del mismo modo lo que llamamos 'alma' forma un sustrato como hipotético pero no sustancial. Tampoco se puede sustancializar el lumen naturale, ni lo divino. Ni se puede hacer a Dios a nuestra imagen y semejanza ni dar a la conciencia filosófica un carácter sobrenatural frente a la conciencia natural. «Ésta ha sido una manía específica de los filósofos que, cual todos los seres, tienden a representarse a Dios como un superlativo de sí mismos. Y así Aristóteles dice: èstí nóesis noéseos (tipografía griega), y ése es Dios; convierte, pues, a Dios en una especie de filósofo en superlativo, nada de particular tiene que venga luego $\mathrm{H}$. Spencer y aspire a hacer de él un mayúsculo ingeniero» ${ }^{271}$.

Toda palabra tiene una dimensión de símbolo que no puede olvidarse para no condenarla al herbolario muerto del diccionario que es la caja de difuntos de toda metáfora viva cuando camina hacia la tumba. Esto ha ocurrido demasiado frecuentemente con lo divino y lo santo: « $\mathrm{Al}$ aplicarse en los últimos siglos la palabra santo a ciertos hombres virtuosos que la iglesia ha canonizado, perdió el vocablo el esplendor ultraterrestre y terrorífico que tiene en la lengua latina y que pervive en fórmulas de la Iglesia misma, como en la antífona que dice a Dios: Tu solus Santus, tu solus Altissimus, o como san Agustín

\footnotetext{
- 268. Ibid., 206.

269. Ibid., 215. El subrayado es nuestro.

270. Ibid., 261. Ricoeur, P., Temps et récit, I, Seuil, Paris 1983. SAN Agustín, Confesiones, Lib. XI.

271. XII 394; IP (1914-1916).
} 
expresaba su sentir cuando se acercaba a Dios: Et inhorresco et inardesco -me horrorizas y me hechizas, me espantas y me entusiasmas» ${ }^{272}$.

Al querer el hombre hacer demasiado realista a Dios lo ha cosificado y petrificado. Lo ha vuelto in-sustancial, lo ha convertido en una sustancia y ha dejado de ser vivo; el Dios vivo y verdadero, se ha convertido en una cosa más, una de tantas cosas con que trafica el hombre. Así ha vaciado el símbolo en cosa.

\subsection{LO DECIBLE Y LO INDECIBLE ACERCA DE DIOS}

Respecto a lo divino admite Ortega como una dialéctica entre lo oculto y lo expresable. Por una parte todos los mundos, incluido el divino, se descubren por los gestos y las palabras humanas. Si esto no fuera así en absoluto tendríamos lo meramente inefable de lo cual realmente no sabemos nada. Todo sería como un jeroglífico del todo intraducible que fuera muy interesante y misterioso pero de cuyo significado y referencia no podemos saber absolutamente nada: «Y cuando el temperamento religioso, penetrando en las soledades extáticas, hace camino por las vías de la oración, odorantes de mirtos, de lirios, de florecillas blancas, y llega a percibir una realidad esplendente que él llama inefable, debemos recordarle que algo inefable debían sentir también los cinocéfalos de Egipto, cuando saludaban al sol naciente con brincos sobre las dunas rosadas del desierto, pues los sacerdotes de Isis los disputaron como ejemplo de fervor y. religiosidad y los propusieron a la imitación de las gentes» ${ }^{273}$.

Ortega recomienda la plenitud de vida frente al ascetismo o el racionalismo de Descartes. Se trata de 'volver a lo sustancial' pero no de mala manera como hicieron los románticos sino con claridad, conscientes también de que lo divino nunca llegamos a alcanzarlo del todo. No se trata de quedarse en lo superficial, hay que hacer la experiencia de lo profundo: «Digo experiencia, porque lo genial no es una expresión ditirámbica; es un hallazgo experimental, es un fenómeno de experiencia religiosa. Schleiermacher encuentra la esencia de lo religioso en el sentimiento de pura y simple dependencia. El hombre, al ponerse en aguda intimidad consigo mismo, se siente flotar en el universo sin dominio alguno sobre sí ni sobre los demás; se siente dependiendo absolutamente de algo - llámese este algo como se quiera. Pues bien; la mente sana queda, a lo mejor, sobrecogida en sus lecturas o en la vida por la sensación de una $a b$ soluta superioridad - quiero decir, halla una obra, un carácter de quien los lí-

272. XII 257; SRH. La razón histórica, Lisboa (1944).

273. I 547; «Problemas culturales», La Prensa (Buenos Aires 15.8.1911). 
mites trascienden por todos los lados la órbita de nuestra dominación comprensiva. El síntoma de los valores máximos es la ilimitación» ${ }^{274}$.

A este respecto discutía Ortega con Baroja. Baroja decía que sólo admiramos lo que no comprendemos. Ortega dice que Baroja no le convenció. Y recalca Ortega que si Baroja no le ha convencido es difícil que alguien le convenza ${ }^{275}$.

Según Ortega, el clásico, el griego, es pobre de cultura emocional y sentimiento religioso; además lo ilimitado le saca de quicio pues todo lo tiene según medida: «Y en cuanto a Dios, nombre colectivo que damos a lo que es ilimitado, infinito en extensión o en calidad, a cuanto rebosa nuestro poder de medir y'prever, ¿hay nada más antihelénico? Es curioso perseguir el desarrollo de la indignación griega contra todo lo infinito. El apeiron (tipografía griega), lo in-definido, lo sin-límites, les saca de quicio» ${ }^{276}$.

Por su parte, el no clásico, el romántico no sabe callarse, dice Ortega. Y al pretender hablar de su íntima experiencia nos deja decepcionados: «Completando una frase ilustre, yo diría que el clásico, como Saúl, parte en busca de unas asnillas que ha perdido y vuelve con un reino, mientras el romántico sale en busca de un reino y vuelve a menudo con las asnillas de Saúl» ${ }^{277}$.

Ortega admite por una parte lo misterioso y por otra su expresión. Según Usener, en el lenguaje religioso, primero se da una manifestación de Dios y luego una condensación del mismo en el lenguaje. Siempre hay un hiato entre ambos como entre el lenguaje lírico y el lenguaje ordinario. En esta línea, según Ortega: «El error general de Cassiser, como de todos, es un desconocimiento de la dualidad interna del logos, del pensar: éste es intuición y abstracción. Hasta Husserl nadie ha visto como lados constitutivos de todo pensar esas dos funciones. A lo sumo se entendía en excepcionales ocasiones y creo que nunca fundiendo bien ambas sino como potencias separadas. Así Kant: Begriffe ohne Anschaung... De aquí que donde la función abstracta del pensar no puede funcionar se salta para explicar el fenómeno noético a intervención del sentimiento- cuando hay entre la emoción y la abstración la intuición. El lenguaje por ej., tiene sí un origen poético pero no porque fuese primariamente expresión sentimental sino porque, en él, expresaba el hombre su intuición que es, por sí, intrasferible. Sólo (por unos) cuantos componentes abstractos de ella, muy generales, salientes, es trasmisible, esto era el concepto (lo abstracto) y la significación de la palabra» ${ }^{278}$.

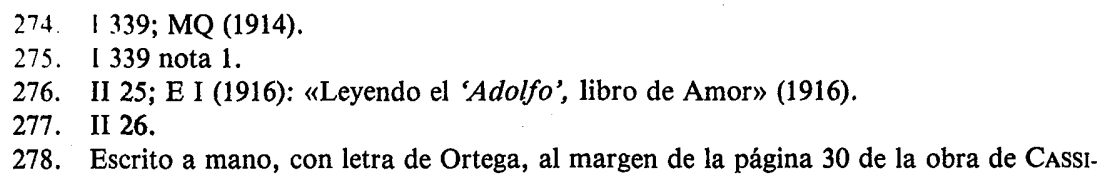


Para Ortega la palabra no es primero, ni aislada. Están juntas las palabras y las cosas. Solamente después comienza una diferenciación progresiva, desde la con-fusión primitiva. Pero esta con-fusión no es previa al pensar, sino al revés pues al «no tener que ver nada con nada, la irrelacción pura y consecuentemente la inteligibilidad habría logrado fundir unas cosas con otras muchas, relacionarlas, confundirlas» ${ }^{279}$. Según Ortega, Cassirer no explica por qué la confusión entre la 'Bild und Sache'. «Pues no es cierto que lo intuitivo quede absorbido - aufgeht - en la palabra sino también viceversa. Es la 'evalescencia' de lo distinto en la unidad mental 'confusionaria'» ${ }^{280}$. Ortega no está de acuerdo en que lo teonómico, lo divino, se identifica con el discurso; según él esto es 'inconcebible'. Para demostrarlo basta con pensar en el nombre de lo divino, en el 'mana': «El concepto 'mana', mejor dicho, lo 'mana' representa, pues, la entidad de un Ente superior y fundamental 'frente al Ente cotidiano', es lo que Platón llamría 'ser más fuerte'» ${ }^{281}$.

Según Ortega lo divino se nombra según el proceso siguiente o «Dialéctica de los nombres de los dioses»: $1 .^{\circ}$ nombre del dios momentáneo. $2 .^{\circ}$ coalescencia de esos nombre en un dios de $n$ nombres. $3 .^{\circ}$ conciencia de que Dios tiene $n+1$ nombres, que trasciende la denominación. $4 .^{\circ}$ Nombre de Dios como el «innombrable». 5. ${ }^{\circ}$ Dios es «silencio», Eckhart, 'el silente desierto'» ${ }^{282}$.

Dios es siempre todavía más, lo totalmente otro, el santo, al que sólo se puede llegar 'via eminentiae' o 'via negationis'. Lo divino es lo desemejante de lo humano. Es algo de por sí y no intercambiable por nada del mundo, en absoluto diverso. De ahí la alegría del descubrimiento intelectual por el que caemos en la cuenta del contraste entre lo absoluto y lo inmediato, el descubrimiento del brillo eterno de las cosas, el sentido festival de la vida. Ortega puntualiza: «Está muy bien. La fiesta es para el que está en ella, para el festeante 'obra' vida, un haber transitado a otro mundo lleno de una (gran) luminosidad, que destaca claramente de la vida cotidiana. En la fiesta todo es lo mismo que la vida corriente y sin embargo, todo es otra cosa» ${ }^{283}$. Todo es nueva claridad en la oscuridad de la vida ordinaria.

Dios es persona pero no es igual que un individuo. A su vez, un numen es

\footnotetext{
RER, E., Sprache und Mythos, Teubner, Leipzig 1926. BO. La cita de Husserl avala su influencia subrayada por varios autores como Orringer, P. Cerezo Galán y otros.

279. Ibid., 40ss. Escrito a mano por Ortega.

280. Ibid., 49. Escrito a mano por Ortega.

281. Ibid., 56. Escrito a mano por Ortega.

282. Ibid., 60. Escrito a mano por Ortega.

283. Escrito a mano, con letra de Ortega, al margen de la página 64 de la obra de KeRENYI, K., Die Antike Religion. Eine Grundlegung, Panteon, Akademische Verlagsanstall, Amsterdam 1942. BO.
} 
impersonal y no es tanto como un Dios. El numen puede ser o mejor estar en la sangre, en un toro, en la zarza ardiente, en la madre tierra, etc... El proceso de formación del numen es como sigue: 1. cosa. 2. relación amigo-enemigo. 3. demonios-dioses. 4. poder de Dios frente al demonio. 5. El uno absoluto ${ }^{284}$.

De lo divino se puede tener una cierta intuición pero: «Si comprehendis, non est Deus» ${ }^{285}$. Dios es la suma novedad, la plena juventud: «Jünger als alles Junge, neuer als alles Neue» ${ }^{286}$ (san Agustín). A Dios le conocemos por las criaturas pero así como nuestra vista natural no puede ver sin la luz tampoco lo divino se puede descubrir sin la sabiduría divina. Sobre un conocimiento inmediato de Dios no sabe nada san Agustín a no ser del que se tiene a través de las criaturas y por su palabra. «Deus veritas est... Hoc enim scriptum est: Quoniam Deus lux est: non quomodo isti oculi vident, sed quomodo videt cor, cum audis: Veritas est. Noli quaerere, quid sit veritas; statim enim se opponent caligines imaginum corporalium et nubila phantasmatum, et perturbabunt serenitatem, quae primo ictu diluxit tibi, cum dicerem: 'Veritas'. Ecce in ipso primo icto quo velut coruscatione perstringeris, cum dicitur: 'Veritas', mane si potes: sed non potes; relaberis in ista solita atque terrena» (De Trinitate, VIII, 3) ${ }^{287}$. Anota Geyser que la teoría de san Agustín no es ningún ontologismo como la de Malebranche que admite un conocimiento inmediato de nuestro espíritu y de Dios ${ }^{288}$. La relación con Dios es doble en san Agustín: como creador presente en su vida y como Luz en las verdades y esencias eternas. Y continúa Geyser: «Damit ist eine natürlich Verbindung der Phaenomenologie mit dem Augustinismus gegeben. Vollzogen hat sie Max Scheler» ${ }^{289}$.

En cuanto a la forma de conocer a Dios, san Agustín piensa que nunca llegaremos a un conocimiento del todo apropiado pero se ve el valor del esfuerzo humano por lo divino. «Pauca sunt enim quae proprie loquimur, plura non proprie; sed agnoscitur, quid velimus» (De Genesi ad Lit. XI,20) ${ }^{290}$. El hombre no se contenta con un Dios abstracto y, forma, con lo mejor que encuentra en sí mismo, una imagen, más o menos aproximada, de Dios: «Todos los templos se erigen, claro está, para la mayor gloria de Dios; pero Dios es

284. Отто, R., Gottheit and Gottheiten der Arier, A. Toepelmann, Giessen 1932, 51; 51; 96. BO.

285. Citado por PrzYwara, E., Gott. Fünf Vorträge über das Religios-philosophische Problem, Oratorium Verlag, München 1926, 22. BO.

286. Ibid., 47.

287. Citado por GEYSER, J., Augustin und die phenomenologische Religionsphilosophie der Gegenwart. Mit besonderer Berïcksichtigung Max Scheler, Aschendorfschen Verlag, Münster in W. 1923, 71. BO.

288. Ibid., 71.

289. Ibid., 75.

290. Ibid., 52. 
una idea general, y ningún templo verdadero se ha elevado jamás a una idea general. El apóstol que vagabundeando por Atenas creyó leer en el frontis de un altar: 'Al Dios desconocido', padeció un grave error; ese hierón no ha existido nunca. La religión no se satisface con un Dios abstracto, con un mero pensamiento; se necesita de un Dios concreto, al cual sintamos y experimentemos realmente. De aquí que haya tantas imágenes de Dios como individuos: cada cual, allá en sus íntimos hervores, lo compone con los materiales que encuentra más a mano. El riguroso dogmatismo católico se limita a exigir que los fieles admitan la definición canónica de Dios; pero deja libre la fantasía de cada uno para que lo imagine y lo sienta a su manera. Refiere Taine que una niña a quien dijeron que Dios estaba en los cielos, exclamó: ‘¿En el cielo, como los pájaros? Entonces tendrá pico'. Esta niña podría ser católica: la definición del catecismo no excluye el pico en Dios. Mirando en nuestro interior, buscamos entre cuanto allí hierve lo que nos parece mejor, y de esto hacemos nuestro Dios. Lo divino es la idealización de las partes mejores del hombre, la religión consiste en el culto que la mitad de cada individuo rinde a su otra mitad, sus porciones ínfimas e inertes a las más nerviosas y heroicas. El Dios de Felipe II, o, lo que es lo mismo, su ideal, tiene en el Monasterio un comentario voluminoso» ${ }^{291}$.

Aristóteles, como era un filósofo, creía que Dios no hace otra cosa que pensar y filosofar. En cambio para el pueblo la teoría es lo que no tiene nada que ver con la realidad. Su Dios debe ser por tanto concreto, como la lluvia, la germinación, las montañas, etc... Para el hombre de acción Dios es pura fuerza y energía. Pero la acción sin contemplación es como andar a golpes en la oscuridad. Para otros, Dios, será el silencio o la presencia inexistente que deslumbra. Ortega lo piensa, a veces, como el origen de toda originalidad: «El prototipo de la originalidad es Dios, origen, padre y manadero de todas las cosas» 292. Los griegos se entusiasmaron con el logos del hombre: «Y como tendemos a proyectar en Dios cuanto parece óptimo, llegaron los griegos con Aristóteles a sostener que Dios no tenía otra ocupación que pensar ${ }^{293}$. Desde el principio de su empresa filosófica preocupó a Ortega la excesiva intelectualización de Dios por el aristotelismo y sus seguidores. Afirma, Ortega, que mientras él acostumbra a contraponer, con Goethe, la gris teoría a la vida, Aristóteles define la beatitud de Dios por la theoría. Y señala el mismo Ortega: «Me parece excesivamente casual que Dios, símbolo de todo movimiento cósmico, resulte un ser ocupado en pensar sobre el pensar. Este afán de divini-

291. II 554-555; E VI (1927): «Meditación del Escorial» (9.4.1915).

292. I 444; POC (1916): «Renan» (4.1909).

293. VII 92-93; HG (1949-1950): «I. Ensimismamiento y alteración» (1939). 
zar el oficio y el menester que cumplimos sobre la Tierra, este prurito de no contentarse cada cual con lo que es, si esto que es no parece lo mejor y sumo, se me antoja un resto de política que perdura hasta en las más altas dialécticas. Aristóteles quiere hacer de Dios un profesor de filosofía en superlativo» ${ }^{294}$.

En cambio para el oriental el silencio es la sabiduría. Todas las cosas tienen un primer momento de misterio. Sólo poco a poco llega el desvelamiento y el conocimiento. No puede todo quedarse en la pura inefabilidad, ni en las cosas ni en lo divino. En otro caso todo quedaría en pura vaguedad o en una noche obscura donde todos los gatos son pardos. Inefable puede ser tanto lo más sublime como lo más bajo. Otra cosa es la inefabilidad del respeto, del sabio que sabe más de lo que dice, y por eso calla. Pero de por sí: «Ser o no inefable es indiferente a la calidad de un conocimiento, puesto que comparte la suerte de lo indecible lo más elevado con lo más humilde. Ni Dios ni el color de este papel pueden ser descritos con palabras. La inefabilidad es una línea fortuita que marca los límites de la coincidencia entre el pensamiento y el lenguaje. Esta línea deja fuera tal vez los grandes picachos de la intelección; pero también elimina trozos mentales de ínfimo valor» ${ }^{295}$.

\subsubsection{Lenguaje, realidad y religión}

Suele distinguirse al hablar del lenguaje como tres aspectos distintos. En primer lugar el lenguaje ordinario que es el que todo el mundo damos por supuesto y utilizamos sin más problemas. Está luego el lenguaje científico que es como el lenguaje 'bien hecho', el lenguaje ideal perfecto, exacto. Como entre ambos, y más allá, está el lenguaje del pensador que es como un ejercicio utópico y paradójico, pues se opone a la opinión corriente y común. Lo mismo ocurre al escritor: «Escribir bien consiste en hacer continuamente pequeñas erosiones a la gramática, al uso establecido, a la norma vigente de la lengua. Es un acto de rebeldía permanente contra el contorno social, una subversión. Escribir bien implica cierto radical denuedo» ${ }^{296}$. El traductor ordinario, en cambio, según Ortega, no tiene este talante, es como el mínimo esfuerzo, y se encuentra atrapado entre la gramática perfecta y el uso mostrenco del lenguaje. Sabemos lo difícil de esta última tarea bien hecha y la dificultad de escapar, por un lado, al uso trivial del idioma y por otro hacerse inteligible. Hoy es necesario trabajar por hacerse entender, pues no es fácil la comprensión interpersonal. Decía Ortega que hablar es un «ejercicio utópico» ${ }^{297}$, paradójico,

294. II, 17, E I (1916): «Verdad y perspectiva» (2.3.1916).

295. II 626; E VII (1930): «El silencio gran brahmán».

296. V 434; IC (10.1940): «Miseria y esplendor de la traducción», La Nación (Buenos Aires 5 y 6.1937$)$

297. V 440 . 
expuesto al malentendido. El mismo pensar es, según Ortega y en el fondo, un malentenderse a sí mismo, es decir, no entenderse al nivel ordinario, encontrar otra dimensión. Para Ortega no es lo mismo comprender las palabras que penetrar a fondo en la realidad. Meillet cree que una lengua dice todo lo que una sociedad necesita. Ortega lo pone en duda, y distingue entre el linguista y el pensador de fondo: «Como lingüista conoce sólo las lenguas de los pueblos, pero no sus pensamientos, y su dogma supone haber medido éstos con aquéllos y haber hallado que coinciden, sobre que no basta decir: toda lengua puede formular todo pensamiento, sino si todas pueden hacerlo con la misma facilidad e inmediatez. La lengua vasca será todo lo perfecta que Meillet quiera, pero el caso es que se olvidó de incluir en su vocabulario un signo para designar a Dios y fue menester echar mano del que significaba señor de lo alto - Jaungoikua - Como hace siglos desapareció la autoridad señorial, Jaungoikua significa hoy directamente Dios, pero hemos de ponernos en la época en que se vio obligada a pensar Dios como una autoridad política y mundanal, a pensar Dios como gobernador civil o cosa por el estilo. Precisamente, este caso nos revela que, faltos de nombres para Dios, costaba mucho trabajo a los vascos pensarlo: por eso tardaron tanto en convertirse al cristianismo y el vocablo indica que fue necesaria la intervención de la policía para meter en sus cabezas la idea pura de la divinidad. De modo que la lengua no sólo pone dificultades a la expresión de ciertos pensamientos, sino que estorba la recepción de otros, paraliza nuestra inteligencia en ciertas direcciones» ${ }^{298}$.

El linguista moderno coincide con Ortega. El lenguaje condiciona lo demás. Abre grandes posibilidades pero cierra otras muchas. Hablar es siempre algo difícil, también el callar. «Cada pueblo calla unas cosas para poder decir otras. Porque todo sería indecible» ${ }^{299}$. En este callar y en el expresar entra toda la vida de cada pueblo y de cada idioma. El nombre de Dios refleja también esa vida del hombre. Cuando ese nombre de Dios es ajeno o contrapuesto a la verdadera humanidad es que algo no ha funcionado debidamente; que la religión ha impuesto un poder indebido, interesado, por tanto maléfico y no benéfico. En ese sentido la lengua puede ser un anacronismo. Podemos ser rehenes del pasado. En parte la lengua impone unas categorías mentales, unas rutas de pensamiento, en parte nos alejamos de esos caminos, los rehacemos, los consideramos maneras de hablar.

Cada pueblo, en su idioma, organiza el mundo a su manera: «La realidad

298. Ibid., 442-443. Se le ha reprochado a Ortega este ejemplo. Creo que no tiene otro valor que el de ejemplo para describir la imagen de Dios que se hace el hombre. En cuanto a la valoración de Ortega de lo vascuence no puede ser más positiva. Sus amistades también demuestran eso mismo.

299. Ibid., 444. 
es un 'continuo de diversidad' inagotable. Para no perdernos en él tenemos que hacer en él cortes, acotaciones, ápartados; en suma, establecer con carácter absoluto diferenciaciones que en realidad sólo son relativas. Por eso decía Goethe que las cosas son diferencias que nosotros ponemos» ${ }^{300}$. Pensamos por carriles linguísticos, cada pueblo considera vías o zonas más importantes que otras: «El indoeuropeo creyó que la más importante diferencia entre las 'cosas' era el sexo, y dio a todo objeto, un poco indecentemente, una calificación sexual. La otra gran división que impuso al mundo consistió en suponer que cuanto existe o es una acción - de aquí el verbo-, o es un agente - de aquí el nombre-》 ${ }^{301}$.

Por eso es tan difícil traducir, no se traducen unas palabras, se traduce una cultura a otra cultura. Se trata de una verdadera transustanciación. Según Ortega sólo Schleiermacher ha traducido bien a Platón. Lo mismo ocurre con el lenguaje religioso. Ortega reconoce que debía haber evitado el ejemplo del Dios vasco «porque la cuestión es muy batallona» ${ }^{302}$. En efecto, es muy fácil introducir en lo divino, como central, algo que es solamente periférico a una experiencia religiosa o que ha sido solamente importante en un momento determinado de la experiencia de un pueblo pero que nada tiene que ver con su vivencia normal de lo sagrado. Pero tales transferencias o transustanciaciones superficiales no son infrecuentes cuando se toca el misterio religioso. Por lo tanto toda la cautela que se tenga en el uso del lenguaje religioso debe darse por bien empleada. Así se evitará la introducción en el ámbito religioso de elementos ajenos a él o también conferir una realidad sagrada a lo que nada tiene que ver con lo divino. No hay que tener excesivo miedo a la difícil experiencia y la nada fácil expresión de lo religioso.

\subsubsection{El místico y lo inefable}

Aunque Ortega no gusta de acudir constantemente al carácter inefable de lo divino, porque el hombre lo que necesita -en esto como en todo- es claridad y orientación, no considera esta cualidad de lo religioso como algo negativo. Se comprende que la mística va hacia lo profundo, hacia lo secreto y misterioso, mientras que la filosofía requiere claridad, salida a la superficie: «Frente al misticismo, la filosofía quisiera ser secreto a voces» ${ }^{303}$.

No obstante, el mutismo de la mística no es una objeticón contra el verdadero misticismo. Como dice Ortega, también el color es 'indecible' y hay

300. Ibid., 446.

301. Ibid., 447.

302. Ibid., 445 .

303. Ibid., 456; = QF (1929): «Defensa del teólogo frente al místico». 
quien ve más y quien ve menos. «Conste, pues, que no es la inefabilidad ni la imposible transferencia del saber místico lo que hace al misticismo poco estimable - ya veremos cómo existen, en efecto, saberes que por su consistencia misma son incomunicables y alientan inexorablemente prisioneros del silencio. Mi objeción al misticismo es que de la visión mística no redunda beneficio alguno intelectual. Por fortuna, algunos místicos han sido, antes que místicos, geniales pensadores - como Plotino, el maestro Eckehart (sic) y el señor Bergson. En ellos contrasta peculiarmente la riqueza, la fertilidad de pensamiento, lógico o expreso, con la miseria de sus averiguaciones extáticas» ${ }^{304}$.

Quizá no haya tanta separación entre una cosa y otra como señala Ortega pero tal es su forma de entender esta cuestión. Y de ahí, de esa desconfianza frente a lo extático, deduce la desconfianza de la gente frente a los místicos y las duras cautelas de la Iglesia en estos asuntos. Dice Ortega: «Comprendo, pues, perfectamente, y de paso comparto, la falta de simpatía que han mostrado siempre las Iglesias hacia los místicos, como si temiesen que las aventuras extáticas trajesen desprestigio sobre la religión. El extático, es, más o menos, un 'frenético'. Por eso se compara él mismo a un hombre ebrio. Le falta mesura y claridad mental. Da a la relación con Dios un carácter orgiástico que repugna a la grave severidad del verdadero sacerdote. El caso es que, con rara coincidencia, el mandarín confuciano experimenta un desdén hacia el místico taoísta, parejo al que el teólogo católico siente hacia la monja iluminada. Los partidarios de la bullanga en todo orden preferirán siempre la anarquía y la embriaguez de los místicos a la clara y ordenada inteligencia de los sacerdotes, es decir, de la Iglesia. Yo siento no poder acompañarlos tampoco en esta preferencia. Me lo impide una cuestión de veracidad. Y es ella que cualquiera teología me parece transmitirnos mucha más cantidad de Dios, más atisbos y nociones sobre la divinidad, que todos los éxtasis juntos de todos los místicos juntos» ${ }^{305}$.

Ortega lamenta del místico que nos comunique tan poco. Después de un tan largo viaje apenas trae nada que contar. El místico incumple el conocido proverbio: El que ha hecho un largo viaje trae mucho que contar. Ortega cree que el futuro de claridad, en la experiencia europea de Dios, está en la teología y no en los subterráneos de la mística. La lucha con Unamuno sigue. Ortega insiste: "Yo creo que el alma europea se halla próxima a una nueva experiencia de Dios, a nuevas averiguaciones sobre esa realidad, la más importante de todas. Pero dudo mucho que el enriquecimiento de nuestras ideas sobre lo di-

304. V 455.

305. Ibid., 456. 
vino venga por los caminos subterráneos de la mística y no por las vías luminosas del pensamiento discursivo. Teología y no éxtasis»" ${ }^{306}$.

Para Ortega de lo que es absolutamente inefable, del todo indecible, no podemos saber nada. No podemos llamarle sabiduría, sea ello lo que quiera. «Si imaginamos un sistema filosófico como el de Plotino o el de Bergson, que mediante conceptos nos demuestra ser el verdadero conocimiento un éxtasis de la conciencia en que ésta traspone los límites de lo intelectual o conceptual y toma contacto inmediato con la realidad, por tanto, sin la mediación o intermediario del concepto, diríamos que son filosofías en tanto que prueban la necesidad del éxtasis con medios n o extáticos y dejan de serlo cuando se arrojan del concepto a la inmersión en el místico trance» ${ }^{307}$.

El místico nos invita a algo maravilloso. Pero no parece que a él le haya llegado tanto, y eso hace desconfiar. El místico: «Nos dice que ha estado en el centro mismo del universo, en la entraña de lo absoluto. Nos propone que rehagamos con él la caminata. Encantados nos disponemos a partir y dócilmente seguir a nuestro guía. Desde luego, nos sorprende un poco que quien se ha sumergido en tal prodigioso lugar y elemento, en tan divino abismo como es Dios o lo Absoluto o lo Uno, no haya quedado más descompuesto, más deshumanizado, con nuevo acento - más distinto y otro de nosotros mismos. Cuando Teófilo Gautier volvió a París de su viaje a España, todo el mundo se lo conoció en la cara, porque la traía tostada por el sol transpirenaico. Según la leyenda bretona, los que bajaban al Purgatorio de san Patricio no volvían a reír nunca» ${ }^{308}$. En cambio, el místico parece intacto a lo que ha visto. A pesar de.ello sus palabras nos seducen y le seguimos: «Pero es tanta la ilusión que nos ofrece el viaje propuesto, que acallamos esta momentánea extrañeza y caminamos resueltos junto al místico. Sus palabras - sus logoi- nos seducen. Los místicos han solido ser los más formidables técnicos de la palabra. Los más exactos escritores. Es curioso - como veremos- paradójico que en todos los lugares del mundo los clásicos del idioma, del verbo hayan sido los místicos» ${ }^{309}$.

El místico nos va llevando de etapa en etapa, con ese suspense que produce el dramaturgo con la segmentación de los diferentes momentos de la secuencia de acontecimientos. «Y, por eso, los místicos dividen siempre su itinerario hacia el éxtasis en virtuales etapas. Unas veces se trata de un castillo dividido en moradas inclusas unas en las otras, como esas cajas japonesas que

306. V 457.

307. Ibid.

308. Ibid., 357-458.

309. Ibid., 458. 
tienen siempre dentro, otras cajas más -así santa Teresa-; otras veces es la subida a un monte con altos en la ascensión, como en san Juan de la Cruz, o bien es una escalera donde cada peldaño nos promete una nueva visión y un nuevo paisaje, como en la escala espiritual de san Juan Clímaco» ${ }^{310}$. El místico nos señala siempre más allá y luego más allá todavía y así indefinidamente. Esto nos desilusiona un poco. Porque nos abandona y él va a sumergirse en su éxtasis. Nos deja solos y cuando vuelve solamente puede decirnos que ha visto algo incontable, indecible. $\mathrm{Y}$ esto nos desazona. No nos ayuda: «El místico de su travesía extramundana no trae nada o apenas nada que contar. Hemos perdido nuestro tiempo. El clásico del lenguaje se hace especialista en silencio"» ${ }^{311}$.

Sea de ello lo que fuere al místico no hay que estudiarle en la clínica sino cogerle por la palabra. «El saber místico es intransferible y, por esencia, silencioso» ${ }^{312}$. Es cierto, no todas las personas son capaces o por lo menos no todas llegan a percibir las realidades definitivas y fundamentales: «Las realidades más sustanciales son atisbadas solamente por unos cantos hombres. Si esto os irrita, ahorcad en la plaza pública a esos seres privilegiados; pero no digáis que la verdadera realidad es la vuestra y que todos somos iguales. Ahorcadlos honestamente, previa declaración de que los estranguláis por ser mejores que vosotros» ${ }^{313}$. El realismo no consiste en ver solamente lo inmediato: «Han olvidado estos presuntos realistas que la realidad histórica más fuerte es el vocabulario y sus eléctricas combinaciones» ${ }^{314}$. De otro lado no hay que descartar nunca, en los asuntos religiosos, sentimientos de envidia y repulsa malévola de lo mejor: «Nietzsche descubrió genialmente el mecanismo del alma rencorosa, lo que el llamó resentimiento» ${ }^{315}$.

Hay que reconocer que el misticismo tiene su propio camino. No se trata del hombre que hace a Dios-objeto y no vive, por tanto, con Dios-sujeto, sabe de Dios cosas pero está separado por completo de él: «Así el alma tiene un Dios, conoce a Dios, sabe de él, pero está separada de Dios» ${ }^{316}$. El error de cierta mística fue querer conquistar a Dios cuanto es él quien viene amorosamente al hombre. Éste es el camino. Y éstos son los pasos que se proponen. En primer lugar, hay que dejar el corazón libre y las cosas un poco aparte, como son realmente, sin confundirnos con ellas como en la vida ordinaria ocurre.

310. Ibid., 458-459.

311. Ibid., 459.

312. Ibid.

313. VI 134; TAO (1942): «Introducción a Don Juan», El Sol (6.1921).

314. VI 135 .

315. Ibid.

316. Schwarz, H., Der Gottesgedanke in Geschichte der Philosophie, I, Heidelberg 1913, 367, nota 1. BO. Cita a Eckhart, II, 203: «Solange die Seele einen Gott hatt, Got erkennt, von Gott weiss, ist sie getrennt von Gott». 
«Así, en san Juan de la Cruz, el punto de partida para todo avance ulterior es 'la casa sosegada'. Embotar los apetitos y curiosidades: 'Un desasimiento grande de todo' - dice santa Teresa, 'un arrancamiento del alma'; esto es, cortar las raíces y ligamentos de nuestros intereses mundanos, plurales, a fin de poder quedar 'embebidos' (santa Teresa) en una sola cosa. Idénticamente pondrá el hindú como condición a la entrada del misticismo: nanatvan na pasyat $i$-no ver muchedumbre, diversidad $\gg{ }^{317}$.

Este primer proceso es una puesta a punto de la atención, un momento de concentración para atender auténticamente a la única y verdadera realidad. Su efecto es parecido al enamoramiento. El alma queda cautivada por la persona amada y desatiende todo lo demás. La sirvienta enamorada rompe más vajilla, que de ordinario, en el fregadero. O se le cae cualqueir cosa pues no está a lo que está. El místico se vacía de todo lo demás, de lo que no concierne a lo divino. Y dice que Dios quiere el alma libre para su encuentro. Queda libre para amar que es ya su único oficio. Y no encuentra en otra cosa beneficio. «El propio san Juan lo dice bellamente: 'Ya no guardo ganado'; esto es, no conservo preocupación ninguna.

Y ahora viene lo más sorprendente: una vez que la mente ha sido evacuada de todas las cosas, el místico nos asegura que tiene a Dios delante, que se halla lleno de Dios. Es decir, que Dios consiste justamente en ese vacío. Por eso habla el maestro Eckhart del 'silente desierto de Dios', y san Juan de la 'noche oscura del alma'; oscura y, sin embargo, llena de luz; tan llena que, de puro haber sólo luz, la luz tropieza con nada y es tiniebla. 'Ésta es la propiedad del espíritu purgado y aniquilado acerca de todas particulares aficiones e inteligencias, que en éste no gustar nada ni entender nada en particular, morando en vacío, oscuridad y tinieblas, lo abraza todo con gran disposición, para que se verifique en él lo de san Pablo: Nihil habentes et omnia possidentes. ('No tienen nada y lo poseen todo.')» ${ }^{318}$.

San Juan de la Cruz llama a este vacío, lleno de plenitud, de Dios, y a esta oscuridad, radiante de luz, 'la soledad sonora'. Y Eckhart dice que cuando llega Dios, su criatura debe quedar fuera, al relente de la noche, y también dice que: «Estar vacío de todo lo creado significa estar lleno de Dios» ${ }^{319}$. Es lo que llaman los teólogos experiencia 'no objetual' de Dios como bien expone Karl Rahner: «La carencia de objeto de que aquí se trata significa la pura receptivi-

317. V 587; SA (1941): «Amor en Stendhal».

318. V 587. Ortega utiliza el libro de BARUzI, J., Saint Jean de la Croix et el problème de l'experience mystique, Paris 1924. BO.

319. Citado por Schwarz, H., Der Gottesgedanke, 347, nota 3. Refiere a Eckhart, E. 14: «Leer sein von allenn Erschaffenen heisst Gottes voll sein». BO. 
dad para con Dios, la indecible experiencia, carente de objeto, del amor de un Dios elevado por encima de todo lo singular, indicable y distinguible, de Dios en cuanto Dios» ${ }^{320}$. Es el abismo de Dios donde las criaturas parecen perdidas.

Dios es un misterio, no un objeto. Si Dios fuera un objeto no sería ya el Dios verdadero sino un ídolo: «Ese Dios a quien cabe mirar no es verdaderamente Dios. El Dios que tiene límites y figura, el Dios que es pensado mediante este o el otro atributo; en suma, el Dios capaz de ser un objeto para la atención, se parece, como tal, demasiado a las cosas del intramundo, para ser el auténtico Dios» ${ }^{321}$. Para el místico, Dios deja de ser externo a él: «Es decir, que deja de ser obiectum y se convierte en iniectum. (Véase Otto: Westöstliche Mystik). Dios se filtra dentro del alma, se confunde con ella o, dicho inversamente, el alma se diluye en Dios, deja de sentirlo como ser diferente de ella. Ésta es la unio a que el místico aspira. 'Queda el alma, digo el espíritu de este alma, hecho una cosa con Dios', comunica santa Teresa en la 'Morada séptima'» ${ }^{322}$. Esta unión no se percibe como algo transitorio sino como definitiva, es como el arroyo o el pequeño río que entra en el mar, dice la Santa. Por su parte, «Eckhart razona muy bien la relativa inferioridad de todo estado en que Dios sea aún objeto de la mente. 'El verdadero tener a Dios está en el ánimo, no en pensar en Dios uniforme y continuamente. El hombre no debe tener sólo un Dios pensado, porque cuando el pensamiento cesa, cesaría también ese Dios'. Por lo tanto, el grado supremo de la mística carrera será aquel en que el hombre se halle saturado de Dios, hecho esponja de la divinidad» ${ }^{323}$. Es como el enamorado. La verdadera personalidad del místico ha emigrado a Dios como el enamorado emigra a su amada y queda absorbido por ella. «También aquí se deja de pensar en el amado, de puro tenerlo dentro» ${ }^{324}$. Se vuelve entonces a las criaturas externas y se las llena de ese amor y ese cariño que invade todo el mundo. $Y$ cesa la fatiga de la vida, ésta se torna ingrávida, pierde acritud. «Es el 'estado de gracia' común al enamorado y al místico. (Como se advierte, no aludo para nada al valor religioso que al estado de gracia corresponda. Es éste aquí estrictamente el nombre de un estado psicológico propio a todos los místicos de todas las religiones). Esta vida y este mundo, ni en bien ni en mal les afectan; han dejado de ser cuestión para ellos» ${ }^{325}$.

320. RAHNER, K., La experiencia 'inobjetal' de Dios, en ID., Lo dinámico en la Iglesia, trad. castellana de A. Ros, Herder, Barcelona 1963, 145.

321. V 588; SA (1941): "Amor en Stendhal».

322. V 588.

323. Ibid., 589.

324. Ibid.

325. Ibid., 590. 
Quien ha dejado las cosas, las vuelve a recibir de Dios, y en Dios: «Así Eckhart: El que ha renunciado a las cosas, las vuelve a recibir en Dios, como el que se vuelve de espaldas al paisaje lo encuentra reflejado, incorpóreo, en la tersa y prestigiosa superficie del lago... El místico, esponja de Dios, se oprime un poco contra las cosas: entonces Dios, líquido, rezuma y las barniza. Tal el amante» ${ }^{326}$. Ortega no cree que sea positivo el sobrevuelo del mundo. Sería descuido o/y falsa bondad.

\subsubsection{Significado, circunstancia, eternidad y verdad}

Todo lenguaje, sea religioso o no, es siempre limitado. No puede decir todo lo decible ni todo lo que hay que decir o/y sería necesario expresar: «No hay ningún decir que diga, sin más, lo que quiere decir. Dice sólo una pequeña fracción de lo que intenta: el resto meramente lo subdice o 'da por sabido'. Esta deficiencia es congénita al lenguaje» ${ }^{327}$.

Además, el contexto resulta prácticamente indecible. No se puede exponer nunca del todo. Y todo lenguaje supone un contexto, una historia. No hay enunciados indefinidos, absolutos, ni verdades eternas, definitivas, en este mundo temporal, referido siempre a una circunstancia concreta. «Tal vez resulta más claro decir esto: pensar es dialogar con la circunstancia. Nosotros tenemos siempre, queramos o no, presente y patente nuestra circunstancia; por eso nos entendemos. Mas para entender el pensamiento de otro tenemos que hacernos presente su circunstancia. Sin esto, fuera como si de un diálogo poseyésemos sólo lo que dice uno de los interlocutores»... «No hay, pues, 'ideas eternas'»" ${ }^{328}$.

El significado de las palabras depende de la circunstancia y del proceso que las enmarca. Ése es el sentido real y concreto de una palabra o expresión. No el sentido del diccionario, vgr., 'negro', sino el que le confiere el momento vital concreto y determinado. "iTras veinticinco siglos de adiestrarnos la mente para contemplar la realidad sub specie aeternitatis, tenemos que comenzar de nuevo y forjarnos una técnica intelectual que nos permita verla sub specie instantis» ${ }^{329}$. Ésa es la diferencia entre la razón pura que nace sólo de la cabeza y la razón histórica que surge de cada instante.

Como cada uno tiene su circunstancia, no puede haber coincidencia de

326. Ibid., 591.

327. VI 390; Prólogp (1914-1943): «A 'Historia de la Filosofía' de Emile Bréhier», Buenos Aires (1942).

328. VI 391.

329. Ibid., 55; «Del Imperio romano», La Nación (Buenos Aires, verano 1940). 
ideas sino correspondencia vital: «Nadie puede tener las mismas ideas que otro si, de verdad, tiene ideas. La idea es personalísima e intrasferible» ${ }^{330}$. Solamente los tópicos son comunes. Ya decían los escolásticos que la persona es incomunicable. Precisamente nuestros sufrimientos en el trato con los otros proceden de que «pensamos, sentimos y somos sobre niveles diferentes» ${ }^{331}$. También pasa lo mismo con las épocas históricas y las religiones; no es lo mismo el cristianismo entre los griegos, o en Roma que en el mundo árabe. Es lo mismo y no es lo mismo: «Ya el islamismo es una imitación del cristianismo ad usum del delfín que vivía en el desierto. Pero también el cristianismo del germano es un remedo del de los padres de la Iglesia» ${ }^{332}$. Hay un cristianismo, también sorprendente, en el escolasticismo y hay también un cristianismo escolástico mostruoso. Como la vida es intransferible son, igualmente, instransferibles las ideas, al menos hasta cierto punto. No se puede trasponer de un espacio cultural a otro una experiencia filosófica o religiosa sin más. Así, para Ortega, «Pretender que aquellos frailes de cabeza tonsurada fueran capaces de entender los conceptos griegos, la idea de Ser, por ejemplo, es ignorar la dimensión trágica que acompaña al acaecer histórico como el hilo rojo va incluido en todos los cables de la Real Marina inglesa» ${ }^{333}$.

Al no circunstanciar debidamente las ideas en la vida, todo escolasticismo, en todas las épocas, ha degradado el saber y la sabiduría a terminología. El escolasticismo árabe influyó negativamente, en este sentido, más que otros escolasticismos europeos. Sin embargo, también trajo el islam una corriente muy fuerte de amor y de nueva mística. Precisamente su poesía lírica hiere la sensibilidad escolástica de ciertos medios españoles. Aquellos de los que dice Ortega que «en nuestro contorno actual hay muchas gentes demasiado convencidas de que el Universo ha sido creado a beneficio de las ursulinas. El tema del amor es tabú, como si fuera algo estrambótico, surgido patológicamente en este Universo que las tales gentes pretenden a su antojo y provecho administrar» ${ }^{334}$.

Todo auténtico concepto describe una situación vital. Claro que las cosas tienen también un valor pragmático. Quizá también un valor absoluto. «Pero aquí no nos ocupamos de qué son en absoluto las cosas, suponiendo que las cosas sean en absoluto» ${ }^{335}$. El mundo es un conjunto de niveles que va desde

330. VII 41; «Prólogo a 'El collar de la paloma' de Ibn Hazm de Córdoba», Sociedad de estudios y publicaciones, Madrid 1952.

331. VII 41.

332. Ibid., 46.

333. Ibid., 47.

334. Ibid., 48-49.

335. Ibid., 129; HG (1949-1950). 
lo más inmediato hasta las alturas supremas del arte y la religión. Cada cosa tiene su propio ámbito en este mundo. Por ejemplo, a las fiestas y las cosas espirituales les pertenece también una reli jión propia. Desde este punto de vista, para Ortega: «En nuestro mundo vital no hay nada material: mi cuerpo no es una materia ni lo son las cosas que con él chocan. Aquél y éstos, diríamos para simplificar, son puro choque y, por tanto, dinamismo» ${ }^{336}$.

La realidad es siempre más, siempre mayor que los conceptos. Las proposiciones matemáticas, decía Einstein, son exactas cuando no se refieren a la realidad. $Y$ si se refieren a la realidad no son exactas. Ni siquiera el sensualismo, o 'la abstracción comunista' es lo mismo que la realidad. La relación verdadera entre conocimiento y realidad sólo se consigue por una 'Purísima Intuición'. Aún así no es nunca ésta toda la realidad. La definición, trata de precisar la intuición; la auténtica predicación es la que recoge totalmente la realidad, la que es 'católica', universal que es «de omni, per se y quoad integrum» ${ }^{337}$. Ya se entiende que esta operación es una utopía. Se ha tratado de salir de esta situación por medio de los juicios sínteticos a priori, éstos encierran como una gran paradoja. Es difícil hacer coincidir a los intérpretes sobre su valor apropiado. Brentano les llamaba «prejuicios sintéticos a priori» ${ }^{338}$. A todo proceso cognoscitivo le falta siempre alguna pieza importante. A veces hay que partir de axiomas. Otras veces o mejor dicho, casi siempre, la prueba lógica no lleva definitivamente a la evidencia y la verdad: «Ésta le llega de lo alto, como un vuelo descendente, como la paloma del Espíritu Santo» ${ }^{339}$.

Aunque la filosofía tiende a la claridad nunca la consigue tampoco del todo. Y aunque la teología, frente al misticismo, quiere hablar de Dios nunca lo hace apropiadamente. $Y$ es que no es fácil expresar lo fundamental. El lenguaje es el empeño permanente de arrancarle al mundo su secreto, es una creación permanente en profundidad. Como todo lo humano el lenguaje «está siempre haciéndose y deshaciéndose ${ }^{340}$. Se ha escrito mucho sobre el origen meramente animal o principalmente divino del lenguaje. Le parece a Ortega que frente a la zoología y la teología está el hombre en su circunstancia. Este hombre es un 'animal fantástico', 'un animal anormal' que tiene necesidad de confesar su intimidad; a la cual, a su vez, le pasa que «El ser más íntimo de cada hombre está ya informado, modelado por una determinada sociedad» ${ }^{341}$. El lenguaje, para bien y para mal, proyecta el alma del pueblo,y sus creencias.

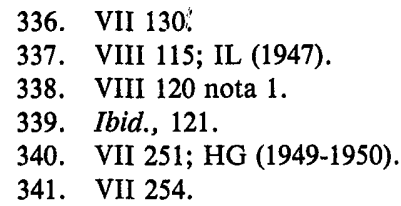


En su diálogo con la realidad, siempre encontramos en el lenguaje un desajuste parecido al del concepto: «Comparado con la cosa misma, el concepto no es más que un espectro o menos aún que un espectro» ${ }^{342}$. Tal condición no debe llevar a una desesperación del lenguaje o de la razón sino a una profundización vital de su manera de ejercerse: «La misión del concepto no estriba, pues, en desalojar la intuición, la impresión real. La razón no puede, no tienen que aspirar a sustituir a la vida. Esta misma oposición, tan usada hoy por los que no quieren trabajar, entre la razón y la vida es ya sospechosa. ¡Como si la razón no fuera una función vital y espontánea del mismo linaje que el ver o el palpar!» ${ }^{343}$.

\subsubsection{El conocimiento, la realidad y el ser}

Las cosas se nos escapan si no las ligamos por medio de la razón. El concepto nos da el esquema y la impresión de la realidad. Hay que superar, por tanto, la razón; eso es necesario, no se trata de suprimirla o suplantarla totalmente: «Pero al destronar la razón, cuidemos de ponerla en su lugar. No todo es pensamiento pero sin él no poseemos nada con plenitud» ${ }^{344}$.

La tarea de conceptualización nos lleva a un acercamiento a las cosas por medio de la experiencia, la prueba y el ensayo; así la razón semántica es prototipo de la razón histórica. Es un andar y ver, correr peligros, fundar el saber en la experiencia, y sólo al final de viajar y revivir se pasa a definirse. En cambio, el escolástico primero definía; es lo contrario de los modernos. Según Ortega, el lumen naturale es una atribución de exactitud donde no lo hay. Para Suárez y santo Tomás sería un hecho último irracional mientras para san Agustín fue un problema tremendo que le lleva a la genial teoría del iluminismo. Pero la Iglesia, no el catolicismo, prefirió a santo Tomás por ser mejor administrador que san Agustín del patrimonio cultural; pues la Iglesia funcionaba como un Estado y el Estado lo que quiere son administradores ${ }^{345}$.

En este último cristianismo, la filosofía, como tal, no interesa, solo importa buscar un modus dicendi sobre Dios, es decir, una terminología general común y para todos: «Pero entonces es congruente que la filosofía se elija como lenguaje, como medio común de ponerse de acuerdo sobre Dios. En última instancia, aun como conocimiento toda filosofía queda a tal distancia de su objeto - Dios-, la mejor es de tal modo incongruente con su tema que quedan todas al mismo nivel. Lo que hace falta es que la filosofía-termi-

342. I 352; MQ (1914).

343. I 353 .

344. Ibid., 353-354.

345. ViII 180 nota 1 ; IL (1947). 
nología en que se hable sea una para todos y constante, como coordenadas de referencia. Cuál se elija dependerá, pues, de cualidades secundarias; por ejemplo, ser una buena y completa terminología, que es lo que es en los seminarios la filosofía. Todo lo contrario que un sistema de cuestiones; a saber: un diccionario de términos» ${ }^{346}$.

En tal sentido, hay un escolasticismo estéril norque no plantea los problemas, sigue el uso común o plausible y no la verdad. No se enfrentan las cuestiones personalmente como lo hace toda auténtica ciencia: «La ciencia es ineludiblemente obra del hombre en su soledad, por la sencilla razón de que pensar -y no sólo repetir mecánicamente- que dos y dos son cuatro es faena que no puede hacer sino quedándose solo consigo ${ }^{347}$. Lo otro es pura dialéctica de plaza pública que nunca llega al alma de las cosas donde mora lo misterioso e ininteligible. Este escolasticismo, recae aparatosamente en el sentido común que es una filosofía hecha con los pies, por la simple lógica de andar por la vida y ver.

Ese pensamiento no pone en cuestión los primeros principios, todo le parece evidente. No sabe que «los conceptos 'primeros' de una ciencia - por tanto, las definiciones y los axiomas - son, en rigor, mostruos lógicos» ${ }^{348}$. Así Suárez que es ya un maestro de maestros -influye en Leibniz- abandona el 'comunismo' escolástico; ese pensamiento donde los primeros principios se reducen a tópicos y lugares comunes; y la rigurosa ciencia se convierte en vagorosa tópica: «El modo de pensar pre-cartesiano se caracteriza, pues, por ser consista, comunista, sensual e 'idiota'» ${ }^{349}$. No se trata de insultar, el 'idiotismo' es lo propio de las cosas comunes. Ortega asistió en su etapa de Marburgo a un seminario de metafísica con Natorp, y ya entonces pudo ver que las pruebas de los primeros principios en Aristóteles son argumentos de quita y pon, son más bien una 'mostración' que una demostración. Y cuando nos falta la evidencia nos sentimos aniquilados ${ }^{350}$.

Para el escolástico todo es tranquilo y estático. También las magnitudes son para él cosas y no relaciones. Cree que Dios ve el universo en su conjunto y así las magnitudes son magnitudes absolutas con unidad de medida.

El Aristóteles usual va con el sentido común a las cosas. Éstas son como se las piensa. No se da cuenta de las modificaciones ad usum Delphinis que se hacen al construir el Ser. Lo mismo ha pasado con la filosofía de Platón establecida como un magma doctrinal; no tiene una palabra técnica que designe

\footnotetext{
346. VIII 181 nota.

347. Ibid.; 170.

348. Ibid., 151.

349. Ibid., 152.

350. Ibid., 198; 199; 203.
} 
'principio'. Usa el lenguaje del ágora. Para él, principio es igual a lo suficiente más lo profundo ${ }^{351}$. Los escolásticos hablan mucho de principios evidentes y eso puede equivaler a irresponsabilidad. Aristóteles, según Ortega, primero habla del Primer Real que identifica con Dios, y luego habla de Real en cuanto real que sería la ontología; se hizo un poco de lío ${ }^{352}$. El ser queda sometido a la opresión del conocer. Es la gente que hace lo que se hace y no sabe a donde va. Convendría, por tanto, no remitirse, sin más, al sentido común que suele ser tan avieso, y tan inocente, como el dos y dos son cuatro. Por eso en todas las grandes revoluciones sangrientas hay matemáticas ${ }^{353}$.

Frente a esta destructividad, Leibniz piensa que la existencia es la más típica perfección. Leibniz duda; no hace como el defensor a ultranza de la evidencia y el sentido común al que no le cabe la menor duda. Leibniz es ya otra época, duda de si el Ente perfectísimo será perfectísimo, como ha dudado dé la existencia de la velocidad máxima o del número mayor. Y pienza Leibniz que si el concepto de Ser perfectísimo es posible entonces existirá ${ }^{354}$. Leibniz es un nuevo talante en filosofía. Pone a prueba la lógica ante la crissis de fundamentos. Lo hace con una serenidad matemática porque la filosofía para él es la serenidad ante la crisis de fundamentos, «la verdad rotunda del corazón impertérrito» ${ }^{355}$. Hoy nos diría que lo peor tampoco es seguro. Que los posibles no son imposibles y pueden existir. «Los posibles son eternos. No han sido originados. No son, como pensaba Descartes con los nominalistas de los siglos XIV y XV, arbitrarias producciones de la voluntad divina. El ser de los posibles radica en ser presentes eternamente al entendimiento de Dios; en rigor són el acto perenne de este entendimiento. Ahora bien, Dios es para la filosofía estrictamente la causa de que la Existencia prevalezca sobre la noExistencia, o, dicho en otros términos, la causa de que haya algo más bien que nada. Dios es Existentificans. Más como ningún posible exhibe razón alguna para existir más y antes que otro, la fuente de existencia que es Dios se extiende, por igual, sobre todos, y ésta es la causa de que 'omne possibile habeat conatum ad Existentiam' o, como diría con una expresión del más hirsuto goticismo escolástico, que 'omne possibile Existiturire' - que todo lo posible está en futuro de existir» ${ }^{356}$. (Philosophische Schriften», VII, 289).

Si nosotros fuéramos Dios, dice Leibniz, veríamos por qué este mundo es el que tiene que existir y no otro. Pero ya que no podemos ser Dios seamos al

351. Ibid., 189; 190.

352. Ibid., 192; 192 nota 2.

353. Ibid., 196.

354. Ibid., 334.

355. Ibid., 336.

356. Ibid., 336-337. 
menos filósofos, amantes de la Sabiduría, es decir, no oprimamos las cosas ni la vida, dejémoslas hablar, y que ellas mismas se dejen ver. No las retorzamos ni las forcemos como el mal novelista a sus personajes que no les deja libertad, que sean lo que son, quiere obligarles a ser como él. El filósofo es por eso respetuoso con la realidad y no deja intervenir a los prejuicios e intereses personales. No dicta de antemano cómo tiene que ser el mundo. En este sentido Ortega llamaba a sus oyentes latinoamericanos a la nueva ciencia: « Argentinos, a las cosas, a las cosas! Déjense de cuestiones previas personales, de suspicacias, de narcisismos» ${ }^{357}$.

Quizá el filósofo no pueda llegar bien a todo. Pero, como al Quijote nadie podrá quitarle su esfuerzo, su respeto, si el éxito no le acompañara. Ortega llama a una rebelión contra el lenguaje establecido y a un nuevo contacto con la circunstancia y con la vida: «jabajo el lenguaje y viva la circunstancia!» ${ }^{358}$. Es el nuevo sacramento de la comunicación humana para entenderse hablando. El pensador está siempre alerta, vigilante ante la realidad de la vida, siempre disponible para la verdad, la que sea. Es, así, eternamente joven: «el joven vive en disponibilidad» ${ }^{359}$, ante el repertorio eterno de la vida. Para él, como para Leibniz, todo es posible, nada debe quedar excluido, ni siquiera la periferia o lo que nos parece accidental en el mundo; pues, como lo primitivo, lo primigenio, como los barrios distantes, es lo que va a salvar la vida actual ${ }^{360}$.

$\mathrm{Ni}$ siquiera hay que olvidar lo que no se suele decir, lo indecible. El pensador verdadero no excluye nada de lo posible; tampoco el poeta cuya poesía habla de lo que el lenguaje, en sentido estricto, no puede decir, de lo inefable vgr., el mundo sensible, el arte de un cuadro, la realidad que nos hace señas y ante la cual el decir es a la vez 'deficiente' y 'exuberante' ${ }^{361}$. Como es necesaria la exactitud en el pensamiento lo es igualmente la apertura y la libertad total en el mismo. No puede el pensador hacer el mundo a su imagen y semejanza. De lo contrario lo convertiría en el cielo de los esquimales: «Cuando los primeros misioneros exponían a los esquimales la doctrina cristiana y les decribían las felicidades de la beatitud en el Paraíso celestial, los esquimales preguntaron:

-Pero ¿en el cielo hay focas?

$\mathrm{Y}$ como los misioneros respondieron que no las había, los esquimales sacudieron preocupados la cabeza y dijeron:

-Entonces el cielo cristiano no sirve para los esquimales. Porque ¿qué hace un esquimal sin focas?

357. Ibid., 390; MPJ (1958): «Meditación del pueblo joven», La Plata, Argentina (1939).

358. VIII 393.

359. Ibid., 403.

360. Ibid., 408.

361. Ibid., 493; «La reviviscencia de los cuadros»: Leonardo, XIII, Barcelona 1946. 
Esta broma, pues se trata solo de una broma de Heine, fundada, tal vez, en el relato de algún misionero, expresa con gracia la efectiva y permanente situación del hombre respecto a su contorno no en la otra vida, pero sí en ésta» ${ }^{362}$.

El filósofo no puede ordenar el mundo de antemano, sólo poco a poco puede poner señales a partir de la confusión primera y el caos original, para evitar un caos mayor o doble y poder salir a lo claro. La realidad inmediata provoca en el hombre 'conversión', 'éxtasis repentino' y 'deslumbramiento'. Kepler vivió años detenido respetuosamente, religiosamente, ante una diferencia. El hombre y las cosas se parecen, comparten un misterio, un mismo secreto de divinidad. Ortega cita Math 18,20 . Y añade: «La palabra es pues, presencia de lo ausente» ${ }^{363}$. De ahí el recogimiento que origina siempre, es como el manantial de toda sabiduría: «El verdadero saber es, como rigorosamente veremos, mudez y taciturnidad. No es como el hablar algo que se hace en sociedad. El saber es un hontanar que únicamente pulsa en la soledad» ${ }^{364}$.

Cuando el manantial ya no es vivo, las aguas quedan estancadas, las ideas pierden su viveza, el pensador deja de ser profeta y visionario y se convierte en un funcionario más. La palabra pierde su valor de anuncio a la humanidad, y el sentido religioso de la averiguación del misterio del hombre reposa únicamente sobre un Deus ex machina impasible. La realidad se congela varada en un gélido pensamiento, el mundo se vuelve puro azar impersonal, sin rostro ni sentido. Es el azar, primer Dios del Hombre primitivo: «no es un Dios personal: Depender pura y simplemente de un poder sobre el cual no cabe ejercer el menor influjo - así definía Schleiermacher la religión-, que es sordo, que es ciego, que, en rigor, es... Nadie» ${ }^{365}$.

El porvenir es ahora inseguro, por eso hay preocupación. No es ya la vida como cúmulo de buena suerte donde todo va bien, el hombre se repite y todo está previamente asegurado, y a la vez momificado por la presencia siempre favorable de lo divino, donde todo va a pedir de boca, como creía el Panteísmo racionalista del siglo XVIII y XIX que en el fondo es un engaño irreal acerca de la vida humana: «Toda esta idea de una naturaleza divina supone un estado de pueril optimismo que permite al hombre de esta época, como de las inmediatas anteriores 'sentirse sostenido y llevado'. No quiere un Dios trascendente de la naturaleza en que estamos y a que pertenecemos porque podría pedir a ésta y a nosotros cuenta, al ser otro y más. Pero si metemos a Dios en la natu-

362. IX 207; IHU (1948-1949).

363. IX 382; OEF (1943-1953): «La mismidad de la filosofía».

364. IX 383 .

365. Ibid., 588; «Goethe sin Weimar» (Conferencia 2.9.1949). 
raleza y creemos est Deus in nobis, entonces todo marcha a pedir de boca. Cuanto pasa está bien.

El panteísmo estoico-humanístico-racionalista del siglo XVIII y comienzos del XIX es el resultado de una gran enfermedad que los griegos nos transmitieron: el optimismo intelectual, el Tout va bien madame la marquise metafísico. Pero Goethe sabía, en estratos más profundos y auténticos, que esa no era la verdad» ${ }^{366}$. Obsérvese de paso que cuanto se ha dicho del panteísmo de Ortega simplemente no ha lugar. Eso no podía ser de otro modo al aceptar Ortega la influencia de Barth y Bultmann.

Lo tenue, lo grácil, lo no consolidado es lo más sensible a los cambios de la vida del hombre. Es el primer anunciador del futuro. Entre los humanos es el arte el mejor detector y más sensible anunciador: «Precede siempre al porvenir histórico, como en la Biblia la mole grave de Jehovah es anunciada por ráfagas» ${ }^{367}$. Los cambios más profundos quedan anunciados por realidades casi insustanciales. Como la idea de progreso fue anunciada por el gran Turgot y desarrollada en el silencio de la cárcel por Concordet, puesto allí por la losa de un canalla y por los eternos imbéciles de la política. A pesar de todo, la idea de progreso se impuso. Ortega se opuso a ella porque además de por la dirección fija de la vida, ésta se mueve también por otra cosa: «Es algo trascendente es... el puro Azar. Lo más esencial de la vida es que es constitutivamente azarosa. Pero dejemos ahora esto" ${ }^{368}$.

Además, muchos no creen en el progreso sino en lo invariable y siempre fijo, no creen en la historia sino en la Naturaleza. El mismo Goethe, y el romanticismo también: «Es la Adoración perpetua. Por eso su última forma, en la generación de Baudelaire, es la Adoración inversa, la blasfemia. Por eso hacia 1850 se practicaba la literatura blasfematoria» ${ }^{369}$. En Goethe la Naturaleza es eterna pero muy sublimada, transubstancializada, sin futurición, y ejemplar.

El filósofo está siempre en camino, rehaciendo y deshaciendo los pensamientos de los humanos. El pensador no deja en paz a los demás animales creados por el buen Dios. Como dijo Ortega a un arquitecto que protestaba por el lenguaje críptico de Heidegger: «El buen Dios necesitaba del 'despensador' para que los demás animales no se durmiesen constantemente» ${ }^{370}$. Ante

366. IX 591-592.

367. Ibid., 604; «Alrededor de Goethe», (Madrid 24.11.1949).

368. IX 607.

369. Ibid., 608.

370. Ibid., 630; «Anejo: En torno al coloquio de Darmstadt (1951), España (Tánger 7, 14 y 21.1.1953). Aquí expone Ortega sus opiniones sobre Heidegger. Copiamos algunas. IX 631: «Heidegger es siempre profundo, y esto quiere decir que es uno de los más grandes filósofos que haya 
el filósofo, el especialista siente sus límites. El filósofo descubre el falso asiento del confiado burgués: Le mueve la silla, le rompe su confianza de aldeano cuando cree y supone que todos saben lo consabido. Que sobre eso no se puede dudar ni discutir. Él se sabe la vida por el diccionario. Esto se lo discute el filósofo. Por eso lo mandará fácilmente a paseo. Pero la vida no está en el diccionario... Hay siempre mucho más: «El lenguaje está limitado siempre por una frontera de inefabilidad» ${ }^{371}$. El escolástico cree en un lenguaje perfecto, que dice todo; eso forma parte del optimismo platónico. Los modernos, como Trubetzkoy, aconsejarán mirar de nuevo las cosas, escuchar lo nunca oído. Así para aprender bien un idioma hay que hacerse como un niño, no tener el mundo hecho ni encajarlo en palabras que no pueden contenerlo. Hay que deshacer los prejuicios: «Si 'Dios existe o no existe', 'si el organismo vivo es una máquina', 'si la democracia es competente o no es competente', he aquí problemas que a toda hora nos acosan y nos hostigan. Ahora bien todos ellos son parejas de juicios antitéticos. Los juicios son quienes excluyen, no las estructuras a que ellos se refieren o que ellos juzgan» ${ }^{372}$.

La realidad, como lo divino, guarda constantemente su secreto. $\mathrm{Y}$ arrancárselo es una tarea constante, infatigable, sin descanso. Nada nos autoriza a excluir nada. Ni hemos agotado todo con una definición ni con una palabra. Siempre queda más. La filosofía no es cosa hecha, hay que estarla siempre haciendo. «La filosofía es ortopedia de la creencia fracturada.

...De aquí que hayan menester de la filosofía hecha los que nunca hubieran de suyo necesitado hacerla. Como en Derecho existe la fundamental distinción de lege lata y lege ferenda, de la ley establecida y de la nueva ley que conviene estatuir, la filosofía tiene dos significados muy distintos: como necesidad de recibir una filosofía ya hecha, y como necesidad - se entiende auténtica y no ficticia, veleidosa y por prurito- de hacer otra filosofía, porque las que hay parecen no serlo» ${ }^{373}$. La filosofía verdadera, como el lenguaje definitivo o la religión verdadera o la auténtica divinidad es siempre la que se busca.

\footnotetext{
habido nunca». Ibid., 632: «Heidegger, que es genial, padece manía de profundidades... Pero no se malentienda todo esto. He dicho que Heidegger es siempre profundo, y que a veces lo es con exceso y manifiesta cierto prurito de revolcarse en lo abismático, pero no he dicho que sea un pensador especialmente 'difícil'. Estas semanas he oído a muchos alemanes quejarse de su hermetismo. ¿No es injusta esta apreciación? Heidegger, a mi juicio, no es más ni menos difícil que cualquier otro pensador privilegiado que ha tenido la fortuna de ver por primera vez paisajes hasta ahora nunca vistos, que ha navegado... Difíciles, de verdad dificiles -e injustificadamente difícilesson Kant, Fichte, Hegel. ¿Por qué lo fueron? Porque ninguno de los tres vio nunca con plena claridad lo que pretendía haber visto».

371. IX 756; «Comentario al 'Banquete' de Platón» (1946).

372. XII 395; IP (1914-1916).

373. VIII 262; IL (1947).
} 
Esa sabiduría primera, dice Aristóteles en el Libro III de la Metafísica es 'zetoumene epistemé', «La que se busca. La Filosofía nos aparece así como 'la Princesse lointaine'...» ${ }^{374}$.

Por tanto, a filosofar no se puede forzar, como no se puede obligar a creer. Dios es más que nuestro entendimiento. Pero de algún modo se deja ver. Como esa sabiduría a la que se aspira, para la que se tienen ciertas cualidades fundamentales; o la fuerza esencial del misterio que incita al hombre, siempre presente y siempre utópica, que no ha lugar. Y sin embargo el hombre siempre ha luchado por lo que no hay todavía: la justicia, el amor perfecto, la amistad definitiva, la fidelidad absoluta, la felicidad sin fin, la sabiduría plena. No las hay todavía, pero queremos que las haya. No las hay del todo pero algo de eso hay... Es el misterio de la vida.

Domingo NATAl Álvarez

(Continuará)

374. VIII 263. 